Portland State University

PDXScholar

Fall 1-8-2016

\title{
Slope Failure Detection through Multi-temporal Lidar \\ Data and Geotechnical Soils Analysis of the Deep- Seated Madrone Landslide, Coast Range, Oregon
}

Michael Scott Marshall

Portland State University

Follow this and additional works at: https://pdxscholar.library.pdx.edu/open_access_etds

Part of the Geology Commons, and the Geomorphology Commons Let us know how access to this document benefits you.

\section{Recommended Citation}

Marshall, Michael Scott, "Slope Failure Detection through Multi-temporal Lidar Data and Geotechnical Soils Analysis of the Deep-Seated Madrone Landslide, Coast Range, Oregon" (2016). Dissertations and Theses. Paper 2656.

https://doi.org/10.15760/etd.2652

This Thesis is brought to you for free and open access. It has been accepted for inclusion in Dissertations and Theses by an authorized administrator of PDXScholar. Please contact us if we can make this document more accessible: pdxscholar@pdx.edu. 
Slope Failure Detection through

Multi-temporal Lidar Data and Geotechnical Soils Analysis

of the Deep-Seated

Madrone Landslide,

Coast Range, Oregon

by

Michael Scott Marshall

A thesis submitted in partial fulfillment of the requirements for the degree of

Master of Science

in

Geology

Thesis Committee:

Scott F. Burns, Chair

William J. Burns

Adam Booth

Portland State University

2015 


\begin{abstract}
Landslide hazard assessment of densely forested, remote, and difficult to access areas can be rapidly accomplished with airborne light detection and ranging (lidar) data. An evaluation of geomorphic change by lidar-derived digital elevation models (DEMs) coupled with geotechnical soils analysis, aerial photographs, ground measurements, precipitation data, and numerical modeling can provide valuable insight to the reactivation process of unstable landslides. A landslide was selected based on previous work by Mickleson (2011) and Burns et al. (2010) that identified the Madrone Landslide as potentially active. This study expands on previous work though an evaluation of the timing and causation of slope failure of the Madrone Landslide.
\end{abstract}

The purpose of this study was to evaluate landslide morphology, precipitation data, historical aerial photographs, ground crack measurements, geotechnical properties of soil, numerical modeling, and elevation data (with multi-temporal lidar data), to determine the conditions associated with failure of the Madrone Landslide. To evaluate the processes involved and timing of slope failure events, a deep seated potentially unstable landslide, situated near the contact of Eocene sedimentary and volcanic rocks, was selected for a detailed analysis.

The Madrone Landslide (45.298383/-123.338796) is located in Yamhill County, about 12 kilometers west of Carlton, Oregon. Site elevation ranges from 206 meters (m) North American Vertical Datum (NAVD-88) near the head scarp to $152 \mathrm{~m}$ at the toe. The 
landslide is composed of two parts, an upper more recent rotational slump landslide and a lower much older earth flow landslide. The upper slide has an area of $2,700 \mathrm{~m}^{2}$ with a head scarp of 5-7 $\mathrm{m}$ and a volume of $15,700 \mathrm{~m}^{3}$. The lower earth flow has an area of $2,300 \mathrm{~m}^{2}$, a head scarp of $15 \mathrm{~m}$, and a volume of $287,500 \mathrm{~m}^{3}$.

The landslide was instrumented with 20 crack monitors established across ground cracks and measured periodically. Field measurements did not detect ground crack displacement over a 15 month period. The laboratory analysis of soil samples indicate an $\mathrm{MH}$ soil with a unit weight of $10 \mathrm{kN} / \mathrm{m}^{3}$ and residual friction angle of $28 \phi^{\prime} \mathrm{r}$ which were both used as input for slope stability modeling. Variations in groundwater elevation were used to calculate at factor of safety for the landslide mass. Differential DEMs from lidar data were calculated to generate a DEM of Difference (DoD) raster to identify and quantify elevation changes. Historical aerial photograph review, differential lidar analysis, and precipitation data suggest the upper portion of the landslide failed as a result of a storm that occurred on December 3, 2007 that brought intense, short period rainfall and high groundwater table. 


\section{Acknowledgements}

The following work is a representation of years of late nights, intellectual challenges, and time away from my dear family and friends. The best and worst moments of my pursuit have been shared with many people. It has been a great privilege to spend the years in the Portland State University Geology Department and this work is a testament of the contribution from all of the professors in the Department. I could not have done it on my own; it took a large community to help me through this project.

First, I would like to gratefully and sincerely thank Dr. Scott Burns for his guidance, understanding, patience, and most importantly, his friendship during my long process to achieve this goal. His enormous enthusiasm encouraged me to grow as an engineering geologist and see the world with open eyes for all the possibilities. For everything you've done for me, Dr. Burns, I thank you.

I would like to thank my committee member, Bill Burns, for your support, assistance, and guidance through this process. The first trip to the site with you and Kate Mickelson will long be remembered. It would have been the perfect landslide if it rained. Thank you so much for all the time you have given up to provide me such excellent guidance.

Adam your incredible help in the direction and content of this thesis added a great deal of clarity. Your perspective and guidance pointed out inconsistencies and logic jumps that had been overlooked. Thank you very much for your direction and advice Dr. Booth. You put a beautiful polish to the final product. 
Thank you, Weyerhaeuser for access to the site and your patience with permitting access for so many years. Specifically, I would like to thank Nate Meehan for refreshing the permit every year. I could not have done it without your help.

Thank you to George McFadden and the Bureau of Land Management, for your untiring patience with my requests for new lidar data and allowing me such access that could not have been more important for the completion of this project. Thank you.

Finally, and most importantly, I would like to thank my wife Marci. Her support, encouragement, quiet patience, and unwavering love were undeniably the bedrock upon which the past five years of my life have been built. Her tolerance of my moods and mission focus is a symbol of her devotion and love. She is the reason I could tackle any of this and have the support to complete it. I love you Marci.

I want to acknowledge my two children, Ruby and Leo. They have missed a father at their games, tucking them into bed, and weekends when I was studying. I hope I can make up those missed times in the years ahead.

I would have never achieved this if it weren't for my parents, Michele and Terry. Their guidance and support for my passion of earth science helped to define my existence. Their encouragement and positivity to pursue any dream I had will always be at the center of my being and something I hope to pass along to my children. There is no bigger or more important influence in my life than theirs. 


\section{Table of Contents}

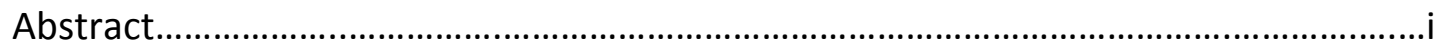

Acknowledgements....................................................................................................

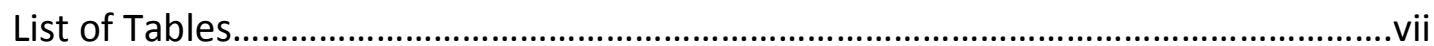

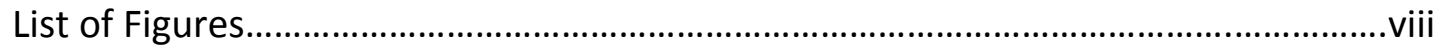

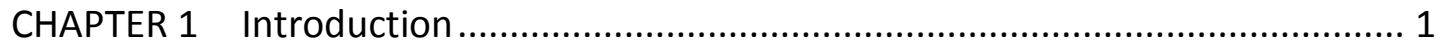

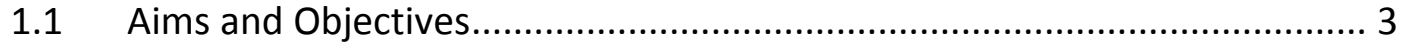

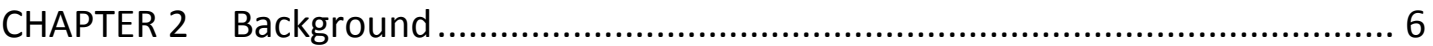

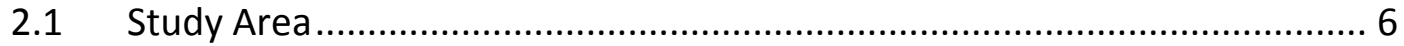

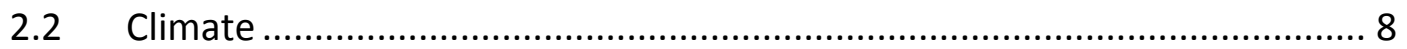

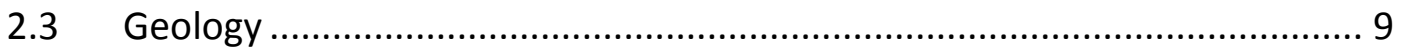

2.4 Previous Work on the Madrone Landslide ............................................. 12

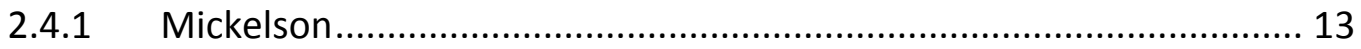

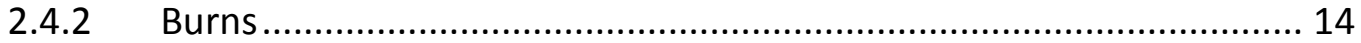

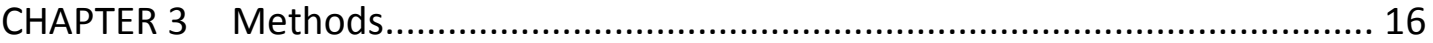

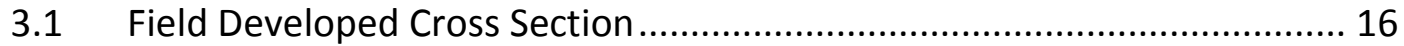

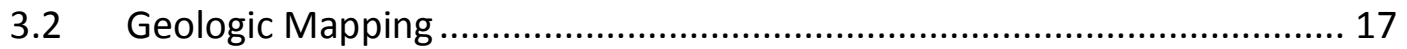

3.3 Precipitation Data Collection ............................................................. 17

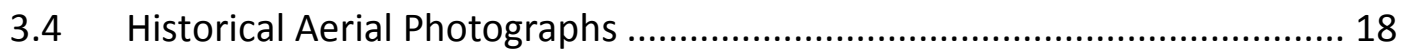

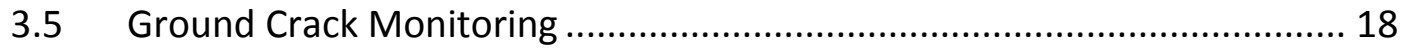

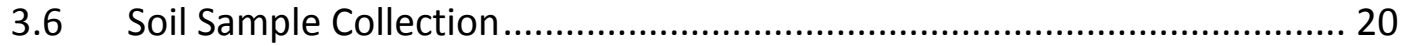

3.7 Laboratory Analysis of Soil Samples ................................................... 22

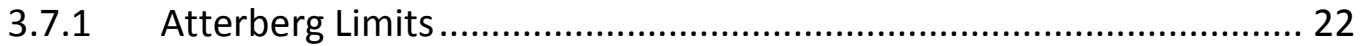

3.7.2 Dry Unit Weight .......................................................................... 22

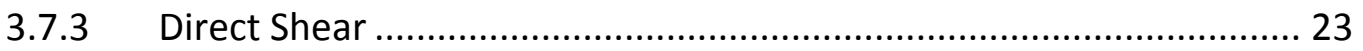

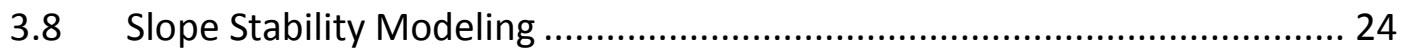

3.9 Multi-temporal Lidar Data Analysis ...................................................... 25

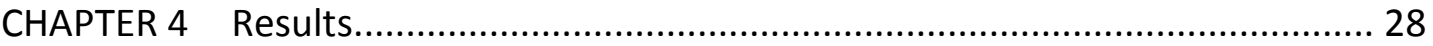

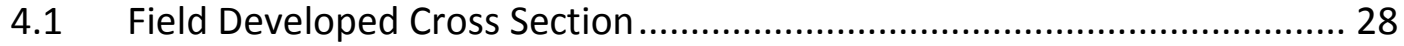

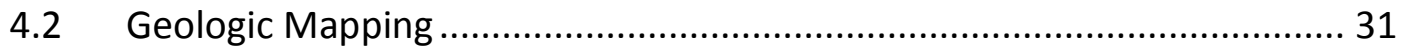




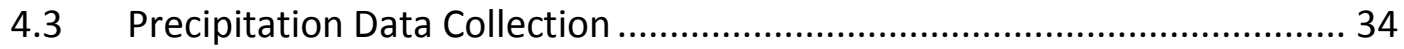

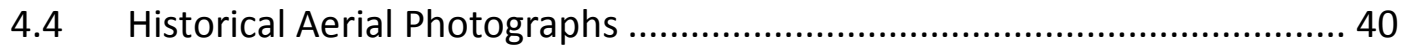

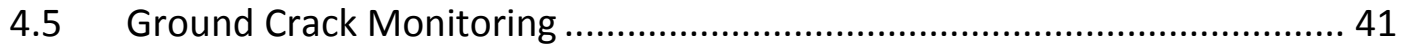

4.6 Soil Sample Collection............................................................................ 43

$4.7 \quad$ Laboratory Analysis of Soil Samples ...................................................... 44

4.7.1 Atterberg Limits .......................................................................... 45

4.7.2 Unit Weight and Shear Strength.................................................... 45

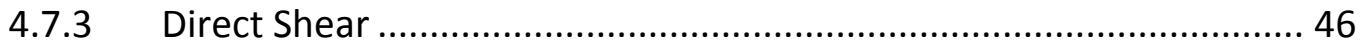

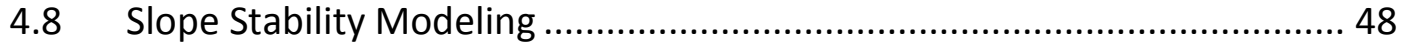

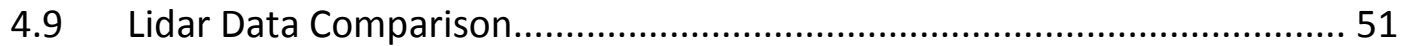

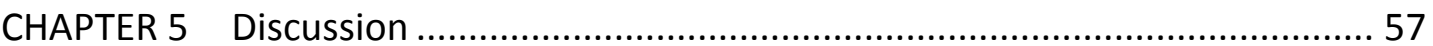

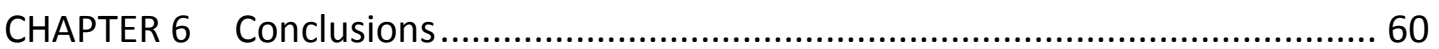

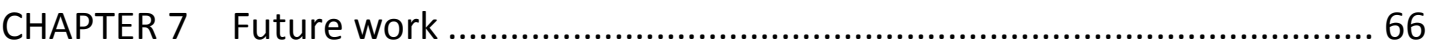

Appendix: Historical Aerial Photographs.......................................................................69 


\section{List of Tables}

Table 4-1. Statistical summary of daily precipitation data from Haskins Dam MET Station for the years 1995 to 2013 .

Table 4-2. Summary of measurements completed at creep monitoring stations. Values are in inches. 42

Table 4-3. Summary statistics for creep measurements. 43

Table 4-4. Soil sample moisture contents and percent passing P200 sieve for hand auger and soil pit

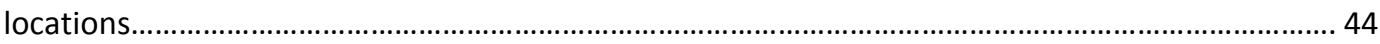

Table 4-5. Summary of Results for Atterberg Limit Test......................................................................45

Table 4-6. Summary of Dry Unit Weight Determination.........................................................................46

Table 4-7. Summary of direct shear testing results for samples S-1 and S-2 .....................................47 


\section{List of Figures}

Figure 1-1. Pacific madrone (Arbutus menziesiiis) a broadleaved evergreen tree and a member of the heath family (Ericaceae). It is distinguished by its smooth trunk, orange-red deciduous bark, white flowers, and red berries (Niemiec et al., 1995).

Figure 2-1. Map of the vicinity of the Madrone Landslide is located. The site is approximately $12 \mathrm{~km}$ west of the town of Carlton, Oregon.....

Figure 2-2. Study area showing the location of the Madrone Landslide in relation to Panther Creek. Light green shades show areas of lower relative elevation, while red to white shades show areas of greater relative elevation. The upper road runs along the headscarp and the lower road runs along the toe.

Figure 2-3. Tectonic map of pacific northwest, showing orientation and extent of Cascadia Subduction Zone (modified from Dragert et al., 1994).

Figure 2-4. Geologic map (Wells et al., 1994) of the vicinity of the Madrone Landslide. The site is located on the Yamhill Formation (Ty), and near units of diabase (Tibd), Siletz River Volcanics Basalt lapilli breccia unit (Tsbr), landslides (Qls), Fluvial deposits (Qf), and older fluvial deposits (Qt). The unnamed inferred fault is mapped at the toe of the landslide.

Figure 2-5. Figure from Mickelson that shows the capture of active movement from the Madrone Landslide over two differential datasets. (a) Original mapped historic landslide in yellow outline. (b) Differential Dataset 1. (c) Differential Dataset 2. (d) Differential Dataset 3. Positive changes in elevation are shown in red and negative elevation changes are shown in red (Mickelson, 2011).

Figure 3-1. Photo of the ground cracks observed in the upper landslide. Foreground shows crack monitoring stations $\mathrm{M} 1$ and $\mathrm{M} 12$, looking northeast. The $0.6 \mathrm{~m}$ rebar rods are driven into the ground and marked with orange flagging. The distance between the two rods at each station was measured periodically...

Figure 3-2. Location of crack monitoring points from the upper landslide area. Shows M1 through M20 crack monitoring locations as black dots and leader lines to labels with the measurement station identification. Ground cracks are shown as hash-marked black lines.

Figure 3-3. Location of soil sample collection points from the upper landslide area. Shows hand augers (HA-1 and HA-2), soil pits (SP-1 and SP-2), and undisturbed samples (UW-1, 2, 3, and 4) locations.

Figure 4-1. Field developed cross-section of the Madrone Landslide. A) Site plan and topography of the landslide showing the upper and lower landslide sections. Mapped head scarp and multiple internal scarps are presented as lines with hatch marks pointing downhill. Cross section line $A$ to $A^{\prime}$ shown in B. B) Cross section of the Madrone Landslide. Failure planes and landslide debris thickness estimated from geomorphology interpretation of the surface terrain

Figure 4-2. Geologic map showing the extent of observed geologic units at the project site. Diabase of Lee's Falls (red) is located over the surface mantling the Yamhill Formation (Tan) below. Location of strike and dip collected in the northeast corner of the map.....

Figure 4-3. Photograph of the outcrop north of the Madrone Landslide that was used to determine the bedding orientation of the Yamhill Formation. Looking north-northwest the bedding appears to be striking approximately $280^{\circ}$ and dipping approximately $17^{\circ}$ to the southwest. 33

Figure 4-4. Annual cumulative precipitation from 1995 to 2013. Average annual cumulative precipitation for this time period is $1,975 \mathrm{~mm}$. The wettest year for precipitation occurred in 1996 with 2,932 mm. Lidar data collection begins in September 2007, a below average year for precipitation. Field instrumentation on the Madrone Landslide was installed in Aug 2012 and continued to May 2014. The driest year in the period presented occurred in 2013.

Figure 4-5. NEXRAD short range base reflectivity data for the December 3, 2007 atmospheric river event. Image is for just after midnight GMT.

Figure 4-6. SLOPE/W slope stability model showing measured groundwater conditions, residual friction angle of $28 \phi^{\prime} \mathrm{r}$ and cohesion of $20 \mathrm{kPa}$. Resulting FS=1.109..... 
Figure 4-7. SLOPE/W slope stability model showing high groundwater conditions, residual friction angle of $28 \phi^{\prime} \mathrm{r}$ and cohesion of $20 \mathrm{kPa}$. Resulting $\mathrm{FS}=1.009$.

Figure 4-8. First period of differential lidar data September 2007 to December 2007. The data collected in December 2007 were subtracted from the data collected in September 2007 to produce the elevation changes presented in the figure. Warm colors represent an increase in elevation and cool colors represent a decrease in elevation. Over this time period, and bracketing a significant storm event, elevation increased up to $6.9 \mathrm{~m}$ at the toe area of the upper landslide and decreased up to $8.4 \mathrm{~m}$ in the head area of the upper landslide......

Figure 4-9. Second period of differential lidar data December 2007 to March 2009. Warm colors represent an increase in elevation and cool colors represent a decrease in elevation. Elevation increased up to $4.7 \mathrm{~m}$ at the ridge associated with the graben for the lower landslide and downstream side of the culvert. Elevation decreased up to $5.2 \mathrm{~m}$ in the head area of the upper landslide.

Figure 4-10. Changes in elevation calculated from March 2009 to July 2010, where elevation increased along the headscarp of the upper landslide and decreased at the ridge associated with the graben for the lower landslide.

Figure 4-11. Changes in elevation up to $4 \mathrm{~m}$ were calculated along the headscarp of the upper landslide and decreases in elevation were observed up to $4.1 \mathrm{~m}$ below the downstream end of the culvert near the toe of the lower landslide 


\section{CHAPTER 1 Introduction}

The catastrophic effects from landslides are well known. The Oso Landslide in Washington claimed the lives of 43 people on March 22, 2014 (Iverson et al., 2015). The landslide occurred near the town of Oso in Snohomish County, Washington following a period of wet seasonal weather and heavy rainfall. The Oso landslide was the most deadly in the history of the United States.

Understanding the landslide failure processes can help to reduce loss of life and property by providing landslide practitioners with the information necessary to advise public officials and land use planners of potentially hazardous areas. Assessment of slope instability of densely forested, remote, and difficult to access areas, can be rapidly accomplished with airborne lidar (light detection and ranging) data. Landslide investigation and monitoring are typically completed by field based methods such as topographic surveys and mapping, geotechnical boreholes and instrumentation, geophysical, and aerial photography interpretation (Johnson and DeGraff, 1988, Keaton and DeGraff, 1996, Cornforth, 2005). The relationship between the pre-failure site conditions and the landslide triggering factors in remote regions are complicated and investigations where site access is difficult with traditional equipment and instrumentation can be prohibitively expensive.

Remote sensing techniques, such as lidar, have great promise in landslide investigation studies as these technologies become less expensive to employ, and 
researchers are able to conduct rapid surveys of the same areas over many years.

Evaluation of these data may prove to be very effective for monitoring deep seated landslides in areas difficult to access by traditional means.

The purpose of this study was to evaluate landslide morphology, precipitation data, historical aerial photographs, ground crack measurements, geotechnical properties of soil, numerical modeling, and elevation data (with multi-temporal lidar data), to determine the conditions associated with failure of the Madrone Landslide. A deepseated potentially unstable landslide, situated near the contact of Eocene sedimentary and volcanic rocks, was selected for a detailed analysis. The landslide was identified during previous work by Mickelson (2011) and Burns et al. (2010). This study expands on previous work though an evaluation of the timing and causation of slope failure of the Madrone Landslide. The landslide in the Panther Creek drainage west of Carlton, Oregon, has been designated the Madrone Landslide due to the prevalent Madrone trees located on the landslide (Figure 1-1).

An assessment of landslide locations and types in the Panther Creek

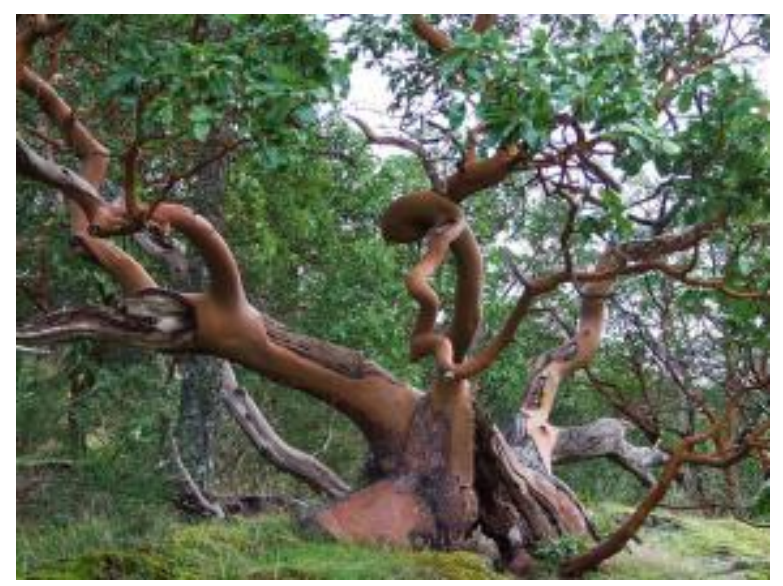

Figure 1-1. Pacific madrone (Arbutus menziesiiis) a broadleaved evergreen tree and a member of the heath family (Ericaceae). It is distinguished by its smooth trunk, orange-red deciduous bark, white flowers, and red berries (Niemiec et al., 1995). 
area was previously completed by Mickelson (2011) who identified the Madrone Landslide by differencing sequential lidar datasets. The lidar derived digital elevation model (DEM) generated from a lidar data collection flight, completed in March 2009, was subtracted from a lidar data set collected in December 2007. The differential DEM that was generated was used to locate active landslides that occurred between the two sequential DEMs. Significant vertical elevation changes between the two data sets were identified and suggested potentially active landslides. The Madrone Landslide was identified as a potentially active landslide.

Burns et al. (2010) also examined elevation changes from two successive lidar DEMs. Part of the evaluation was to determine the effectiveness of multi-temporal lidar in identifying potentially active landslides. Burns et al. (2010) also identified the Madrone Landslide as a potentially active landslide.

\subsection{Aims and Objectives}

By measuring the critical components influencing slope stability and movement, comparisons to other landslides in the region can be drawn and commonalities used to reduce or mitigate potentially hazardous slope conditions. This study aimed to conduct a detailed investigation and analysis to characterize the geomorphic change of the Madrone Landslide and evaluate its stability. The Madrone Landslide was evaluated by installation of ground crack measurement stations, historical aerial photograph interpretation, laboratory geotechnical soils analysis (Atterberg Limits, unit weight 
determination, direct shear testing), elevation surface differencing, and numerical slope stability modeling.

One of the goals of this study was to establish protocol to study potentially active deep-seated landslides.

The aims to achieve this goal included:

1. Characterization of landslide dimensions and morphology.

2. Evaluate precipitation data to determine if a storm event triggered the initial failure of the Madrone Landslide.

3. Evaluate historical aerial photographs for indications of disturbed ground to assess a potential failure period.

4. Periodically monitor movement with ground based ground crack monitoring measurements.

5. Determine physical soil properties such as unit weight, residual shear strength, cohesion that will be used as input for numerical slope stability modeling.

6. Evaluate slope stability modeling results to determine a factor of safety (FS) under static loading conditions which indicate the conditions necessary for reactivation.

7. Assessment of elevation changes identified by multi-temporal lidar data to determine significant slope failure events. 
To accomplish this detailed analysis, the following tasks were completed:

- Field developed cross section,

- Characterization of the landslide dimensions,

- Geologic mapping,

- Precipitation data collection,

- Creep monitoring to determine the rate and direction of movement and failure surface,

- Geotechnical characterization of the soils,

- Slope modeling for stability under static conditions to determine the $\mathrm{FS}$, and

- Multi-temporal lidar data comparison. 


\section{CHAPTER 2 Background}

\subsection{Study Area}

The Madrone Landslide (latitude 45.298383N / longitude 123.338796W) is located in Yamhill County, about 12 kilometers west of Carlton, Oregon (Figure 2-1).

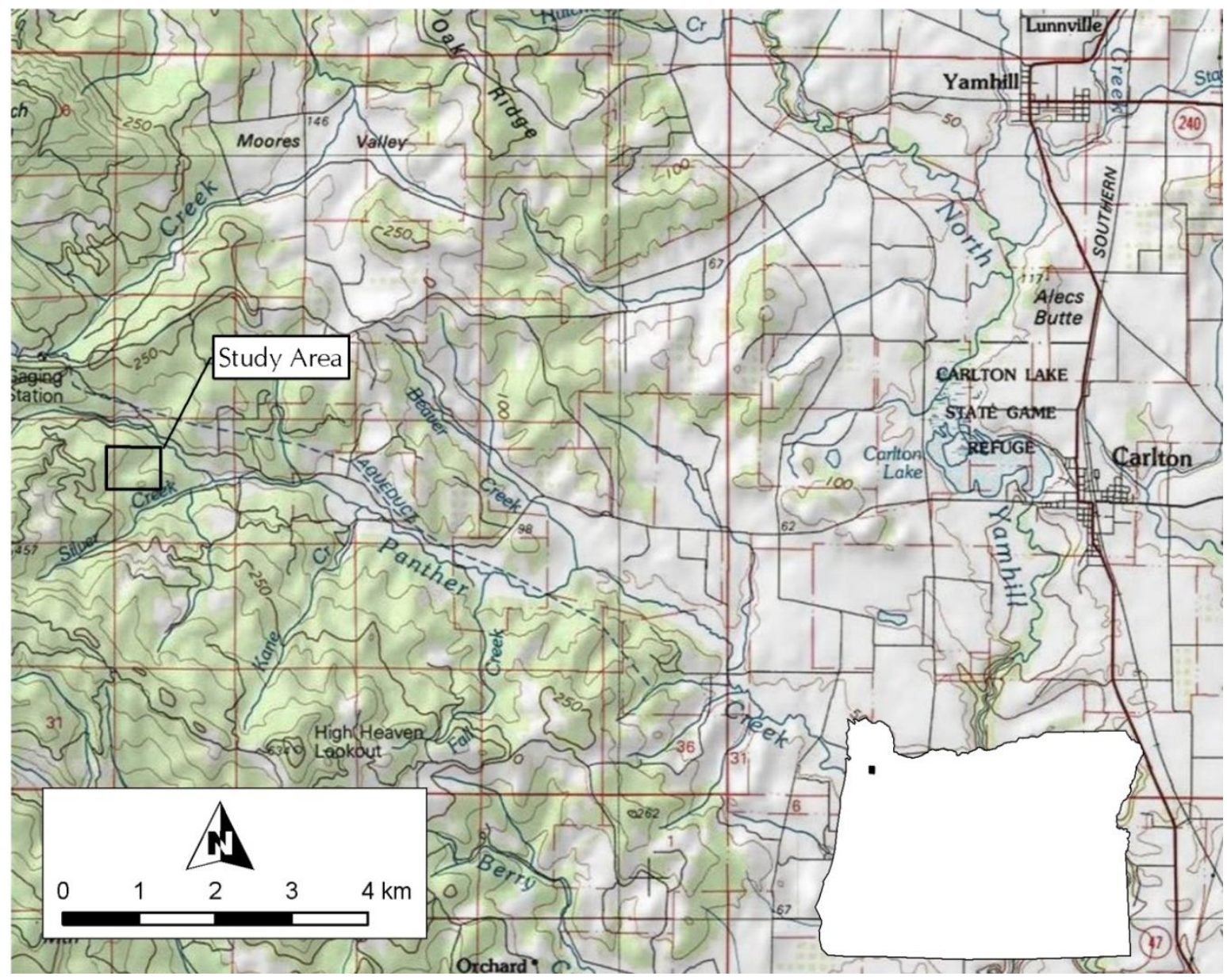

Figure 2-1. Map of the vicinity of the Madrone Landslide is located. The site is approximately $12 \mathrm{~km}$ west of the town of Carlton, Oregon.

The site is in the Fairdale USGS 7.5 minute quadrangle on a parcel of land owned by the Weyerhaeuser Company. To the north and east of the site are private residential and 
timber lands and to the south and west is Bureau of Land Management (BLM) property.

Site elevation ranges from 206 meters $(\mathrm{m})$ national vertical geodetic datum (NVGD-88)

near the head scarp to $152 \mathrm{~m}$ at the toe. The landslide is oriented generally east-west

and slopes down to the east where the toe terminates into an unnamed creek (Figure

\section{2-2).}

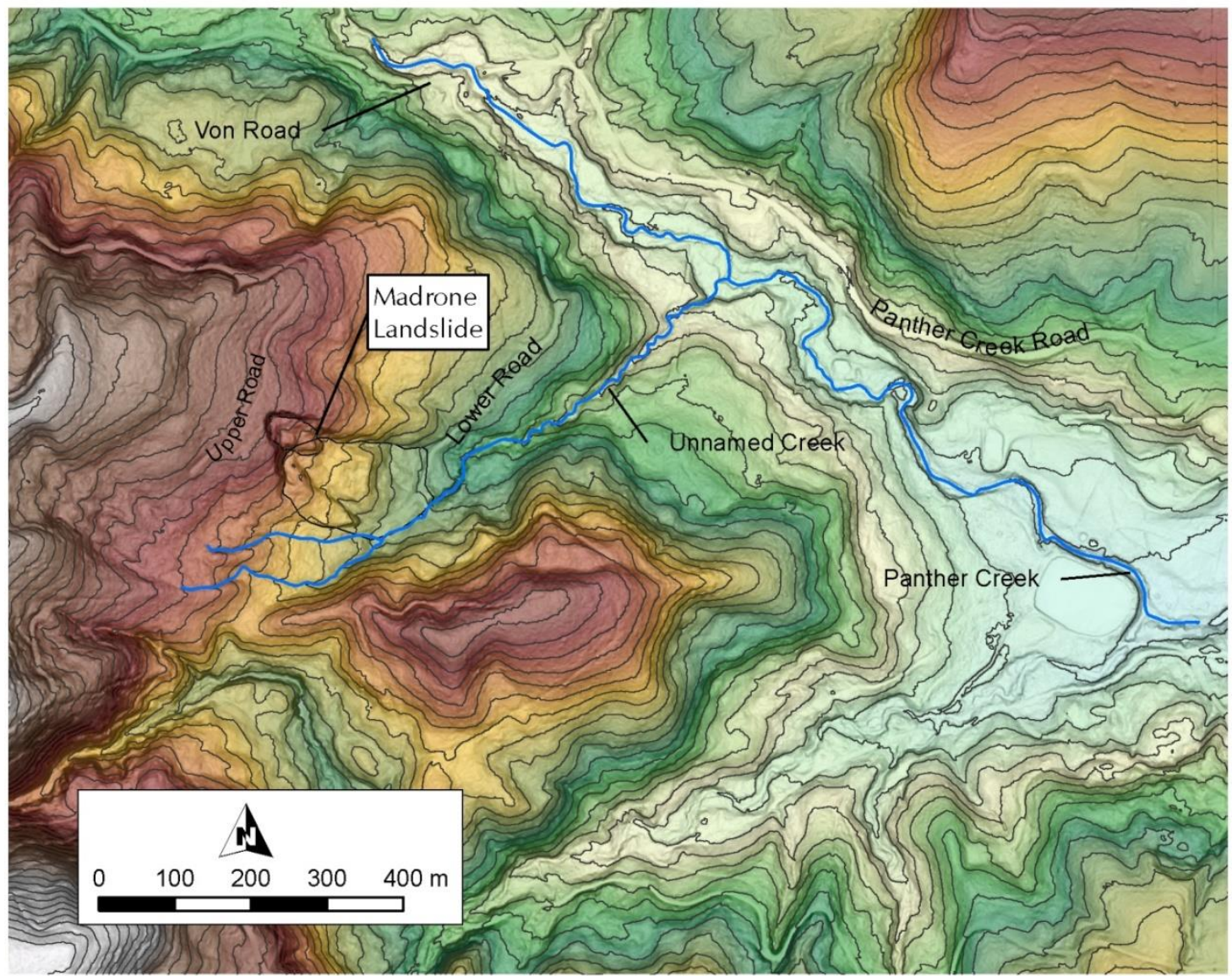

Figure 2-2. Study area showing the location of the Madrone Landslide in relation to Panther Creek. Light green shades show areas of lower relative elevation, while red to white shades show areas of greater relative elevation. The upper road runs along the headscarp and the lower road runs along the toe. 
The unnamed creek generally flows from southwest to northeast along the toe of the landslide and drains to Panther Creek approximately $462 \mathrm{~m}$ north of the toe. Panther Creek continues to flow east after the confluence with the unnamed creek. Elevation increases west of the landslide headscarp to crest at a ridgeline with an elevation of about $248 \mathrm{~m}$ and located approximately $270 \mathrm{~m}$ west of the headscarp. The ridgeline crest is generally oriented north-south. The landslide is bounded at the top and the bottom by access roads developed for lumber harvest. The lower road is east of the toe of the landslide but wraps around the southern flank of the landslide. The upper road runs along the headscarp west of the landslide. The upper road and lower road meet northeast of the landslide and then parallels the unnamed creek until an intersection with NW Von Road. To the northeast of this intersection, Von Road crosses Panther Creek and meets NW Panther Creek Road on the north side of Panther Creek (Figure 2-2).

\subsection{Climate}

Yamhill County has a mild, humid climate with a mean annual temperature of $9.4^{\circ} \mathrm{C}$ and approximate 107 centimeters $(\mathrm{cm})$ of precipitation per year (Taylor 2014). Precipitation information from a nearby weather station indicates local annual average precipitation is closer to $200 \mathrm{~cm}$ per year. With the mild temperatures, the county generally experiences two principal seasons, a wet and a dry season. The majority of rain occurs between about the middle of October to middle of May. Very little rain 
occurs between May and September and may only be a few centimeters over this four month period (Taylor 2014).

\subsection{Geology}

The site is located east of the crest of the Oregon Coast Range, which is a northeast plunging anticline of uplifted Eocene to Miocene sedimentary and volcanic

rocks along the western edge of Oregon (Wells et al., 1994). The uplift is a result of tectonic plate convergence associated with the Cascadia Subduction Zone (CSZ) tectonic system. The CSZ extends along the western margin of North America for 1,100 km and represents the surface expression of an active plate boundary along which remnants of the Farallon Plate (the Gorda, Juan de Fuca, and Explorer plates) are being subducted beneath the western edge of the North American continent. The subduction zone is a broad, eastward-dipping zone of contact between the upper portion of the subducting slabs of the Gorda, Juan de Fuca, and Explorer plates and the over-riding North America Plate

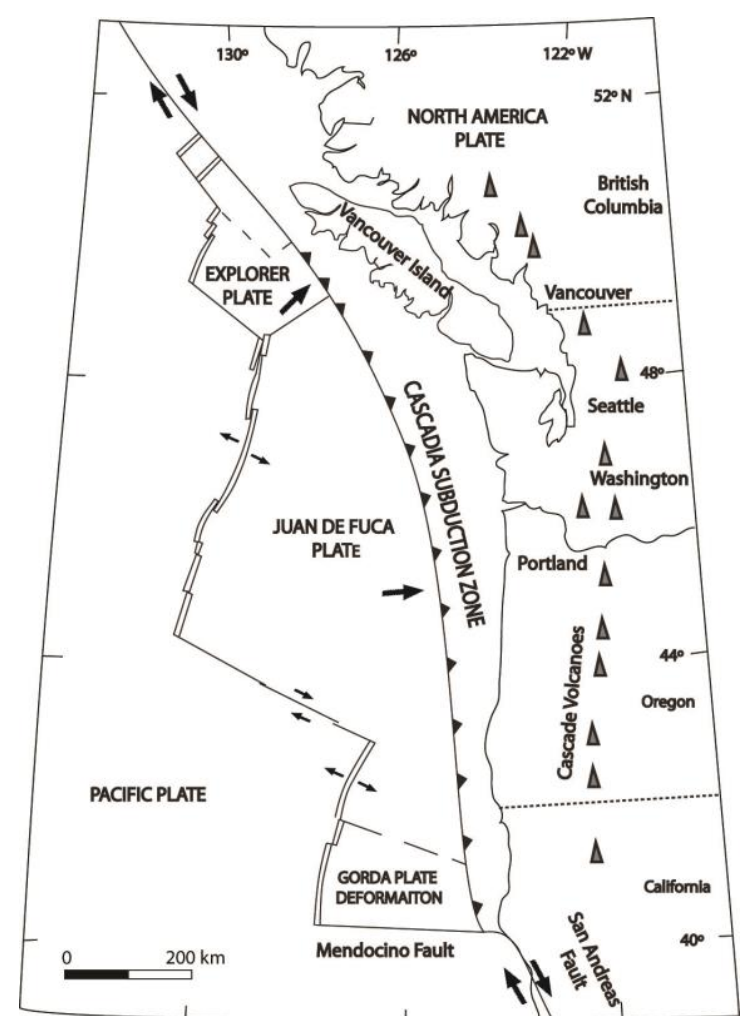

Figure 2-3. Tectonic map of pacific northwest, showing orientation and extent of Cascadia Subduction Zone (modified from Dragert et al., 1994) 
(Figure 2-3). This tectonic regime has compressed and folded the geologic units of the northern Coast Range, creating a northward-trending anticlinal form of the crest of the Coast Range (Brownfield, 1982). The Willamette Valley is located east of the Coast Range and is a structural fore arc basin that has filled with river and stream sediments from the Coast Range and the Cascade Mountains east of the Willamette Valley. The Cascade Range represents the volcanic arc forming from the melting subducting oceanic plate.

Geologic structure in the area is primarily a broad, north-northeast trending arc dissected by northwest and northeast trending faults. There are a number of mapped faults near the site and an inferred fault is mapped parallel to the unnamed creek at the landslide toe (Figure 2-4). This inferred fault ends perpendicular to an inferred and uncertain fault running parallel to Panther Creek (Wells et al., 1994). The Yamhill River Fault zone is located about $4 \mathrm{~km}$ north of the site (Wells et al., 1994; Wells et al., 1983). The USGS does not consider these faults to be active faults which are believed to be sources of $M>6$ earthquakes during the past 1.6 million years (USGS, 2006). 


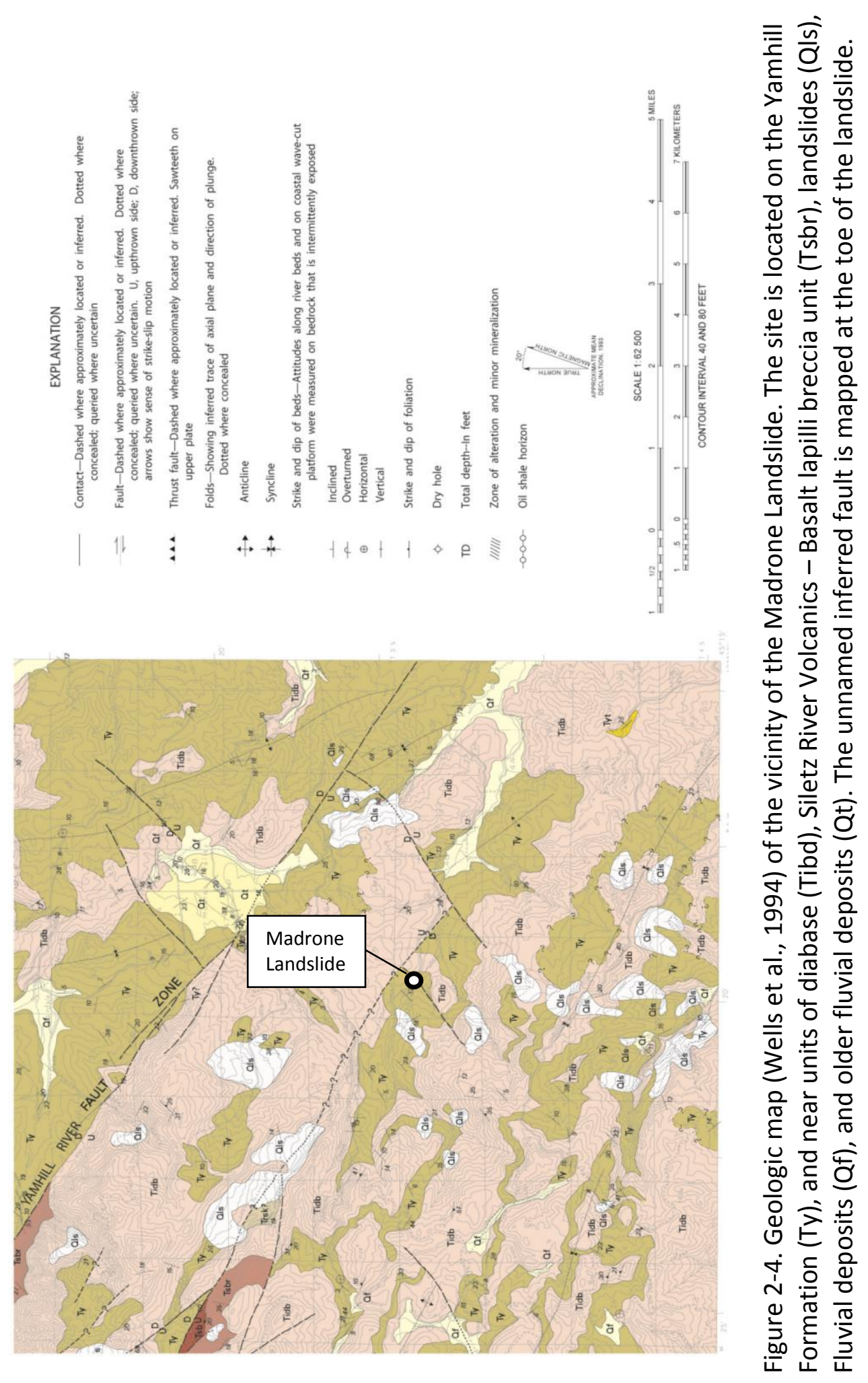


The site is underlain by Eocene deep marine sedimentary rocks consisting of dark gray, massive to thinly bedded tuffaceous siltstone, clayey siltstone, and fine-grained arkosic sandstone of the Yamhill Formation (Figure 2-4). Calcareous concretions and carbonaceous plant fragments have also been observed. The Yamhill Formation contains interbeds of thin laminated, black, kerogen-rich "oil shale" near the top of the section where it is interbedded with submarine basalt lapilli breccias of the Tillamook Volcanics (Snavely et al., 1993).

The Diabase of Lees Falls intrudes the marine sedimentary rocks of the Yamhill Formation. The Diabase of Lee's Falls (Eocene to Miocene) intrusive rocks are primarily diabase sills and dikes of aphyric to plagioclase-phyric, amygdaloidal diabase with smectite clays and zeolite vesicle fillings; locally they are pillowform with radial columnar joints, more commonly tabular bodies with well-developed columnar joints and a layered appearance. Sills are cut by the regional dike swarm that fed Tillamook Volcanics but intrude rocks as young as Yamhill Formation, suggesting a minimum age of about $43 \mathrm{Ma}$ (Wells et al., 1983). Weathering of the Yamhill Formation where diabase sills are present makes it difficult to identify from older geologic units (Wells et al., 1994).

\subsection{Previous Work on the Madrone Landslide}

The Madrone Landslide has been involved in two other research efforts completed in the Panther Creek area. This additional research includes work completed for a 
Master of Science in Geology by a student at

PSU (Mickelson 2011) and by the Oregon

Department of Geology and Mineral Industries

(DOGAMI) (Burns et al., 2010).

\subsubsection{Mickelson}

The master thesis work by Mickelson (2011)

completed a landslide inventory and susceptibly

map for Panther Creek. The study used lidar

data collected in the Panther Creek Watershed,

to map pre-historic, historic, and active

landslides. Each mapped landslide was

characterized as to type of movement, head

scarp height, slope, failure depth, relative age,

and direction. The work included the evaluation

of elevation changes from lidar collected at

different times of year, approximately one year

apart, to locate potentially active landslides.

Twenty-six landslides were considered active

based upon differential lidar data, and the

Madrone landslide was included as a potentially

active landslide. Three differential lidar datasets

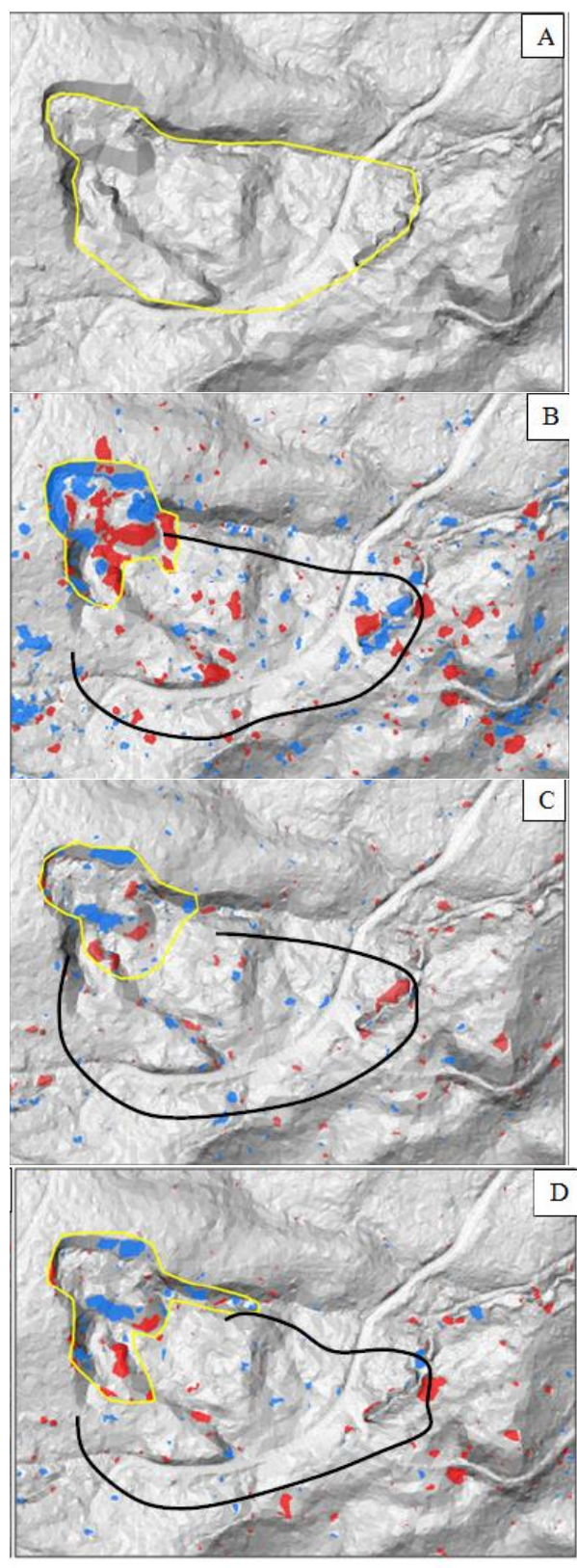

Figure 2-5. Figure from Mickelson that shows the capture of active movement from the Madrone Landslide over two differential datasets. (a) Original mapped historic landslide in yellow outline. (b) Differential Dataset 1. (c) Differential Dataset 2. (d) Differential Dataset 3. Positive changes in elevation are shown in red and negative elevation changes are shown in red (Mickelson, 2011). 
were created for the evaluation: September 2007 and December 2007 (Differential

Dataset 1), December 2007 and March 2009 (Differential Dataset 2), and March 2009 and March 2010 (Differential Dataset 3). Mickelson (2011) concluded that significant movement of the head scarp was detected in Differential Dataset 1 (Figure 2-5), and the following two differential datasets showed minor movement.

\subsubsection{Burns}

Burns et al. (2010) examined elevation changes detected from two successive sets of lidar data to identify active landslides. The study collected field measurements landslide scars, travel paths, and deposits to assess the vertical accuracy of the lidar data. In addition, one set of lidar data was acquired during spring / summer (leaf-on conditions) and the second set during fall / winter (leaf-off conditions). Active landslides were identified using the differential DEM, but thresholds of $0.50 \mathrm{~m}$ and $0.75 \mathrm{~m}$ were necessary to remove noise from the elevation data (Burns et al., 2010). Field verification confirmed 88 percent of landslides with DEM data. The analysis concluded that the volumetric calculations between the two datasets indicated $18,100 \mathrm{~m}^{3}$ of material was unaccounted for in landslide areas. The group suggested that the material loss may have been due to systematic negative elevation errors in the differential DEM due to local vegetation differences from leaf-on to leaf-off conditions. They also suggested that erosion and transport could account for the calculated material loss between the two datasets. A comparison of lidar and survey data indicated an overall root mean square error of $0.50 \mathrm{~m}$, a maximum error of $2.21 \mathrm{~m}$, and a systematic error of $0.09 \mathrm{~m}$ (Burns et al., 2010). Lidar data collected from young conifer forests and deciduous vegetation 
showed ground-point densities leaf-on season of 0.15 points $/ \mathrm{m}^{2}$ and leaf-off season, the average density of points in the same area is 1.1 points $/ \mathrm{m}^{2}$. The leaf-on, bare-earth DEM in these areas, required substantial interpolations of elevations which decreased data quality. The study concluded that data sets be flown during leaf-off seasons to obtain higher quality multi-temporal lidar data in forested areas (Burns et al., 2010).

The study determined the Madrone Landslide showed positive volume increase of $5,551 \pm 38 \mathrm{~m}^{3}$ and decrease of $-3,940 \pm 31 \mathrm{~m}^{3}$ between the successive lidar data sets. The net change in volume was an increase of $1,611 \pm 49 \mathrm{~m}^{3}$ (Burns et al., 2010). The study cautioned that great care was needed when interpreting volume changes due to the impact of leaf-on/leaf-off conditions in the differential lidar DEM and actual changes caused by removal of material by transport and erosion must be taken into account when interpreting lidar-derived volumetric data. 


\section{CHAPTER 3 Methods}

\subsection{Field Developed Cross Section}

A detailed field developed cross section and plan view was developed in general conformance with the techniques described by Williamson et al. (1991). This method involves the measurement of the distribution of terrain features such as scarps, minor scarps, landslide boundaries, toes, and geomorphic features of landslide terrain. These features were mapped using a combination of total station, aerial photographs, and GPS data. Limited subsurface data was obtained with two hand auger borings, two handexcavated soil pits, and four relatively undisturbed soil samples. Limited groundwater information was collected during hand auger explorations. Cross section data were obtained from lidar data collected in April 2012 and were used for the profile in slope stability modeling.

Diagnostic landslide morphologic features were measured. The landslide dimensions of width of the displaced mass, length of displaced mass, length and depth of failure plane, scarp height, volume of displaced mass, and area of displaced mass, depth to failure plane were calculated (Cornforth, 2005; Cruden and Varnes, 1996). The pre-failure slope angle was determined by measurement of the slope angle of stable ground next to the landslide and head scarp height. These measurements were used to calculate the estimated slope normal thickness or depth of failure by:

$$
t=x \cos (a)
$$




$$
\begin{aligned}
\text { Where } t & =\text { the slope normal thickness } \\
x & =\text { scarp height } \\
a & =\text { pre-failure slope angle }
\end{aligned}
$$

The landslide volumes were determined by multiplying the slope normal thickness, or estimated depth to failure plane, by the area of the landslide calculated in GIS.

\subsection{Geologic Mapping}

A detailed geologic map of the site was completed on a lidar derived topographic base map. GPS data and hand measurements were used at outcrop locations. These data were used to construct geologic unit contacts, and structural details where observed. BLM and Weyerhaeuser roads in the vicinity of the Madrone Landslide were traversed by vehicle to identified outcrop locations. Information on the rock type and structure were recorded where observed. Evidence of landslide terrain adjacent to the Madrone Landslide was also noted where observed.

\subsection{Precipitation Data Collection}

Soil moisture and rainfall intensity are key factors affecting marginally stable slopes. Rainfall-induced landslides can happen within minutes of a high intensity rainfall event, however, the wet soil moisture conditions that often precede them can take several hours or days to develop and generally need to be sustained for failures to occur.

Daily precipitation data were obtained from a nearby weather station located at the Haskins Dam site (USGS 37050000 3705) located 1.2 km northwest from the Madrone Landslide. Data from the USGS National Water Information Center were queried for 18- 
year period from 1995 to 2013 . The station is located at latitude $45.1898384 \mathrm{~N}$, longitude -123.2112162W (NAD83) and at an elevation of 231 m (NAVD88).

\subsection{Historical Aerial Photographs}

Historical aerial photographs of the site were obtained from the University of Oregon Map Library. Aerial photographs for the years 1948, 1953, 1956, 1963, 1970, 1980, 1988, 1993, 1995, 2000, 2003, 2005, 2008, 2009, and 2012 were examined. Photo-interpretation involves systematic examination of photographs to identify features that would indicate changes in topography occurring between photo dates. The historical aerial photos were orthorectified in a GIS environment and observations made of changes from previous photograph dates. Photographs were examined for diagnostic surface morphology of landslide movement such as areas of exposed or disturbed soil, areas exhibiting curvilinear topographic expressions such as head scarps, secondary scarps, sag ponds, and ground-crack patterns that may be observed (Turner and Schuster, 1996; Cornforth, 2005).

\subsection{Ground Crack Monitoring}

Ground crack monitoring stations were established to track potential ground movements. At 20 locations, two $0.6 \mathrm{~m}$ long rebar rods driven into the ground were installed on opposite sides of a ground crack (Figure 3-1). The distance between the rebar rods, downhill azimuth, and angle of a straight line between the tops of the rods were periodically measured and recorded. 


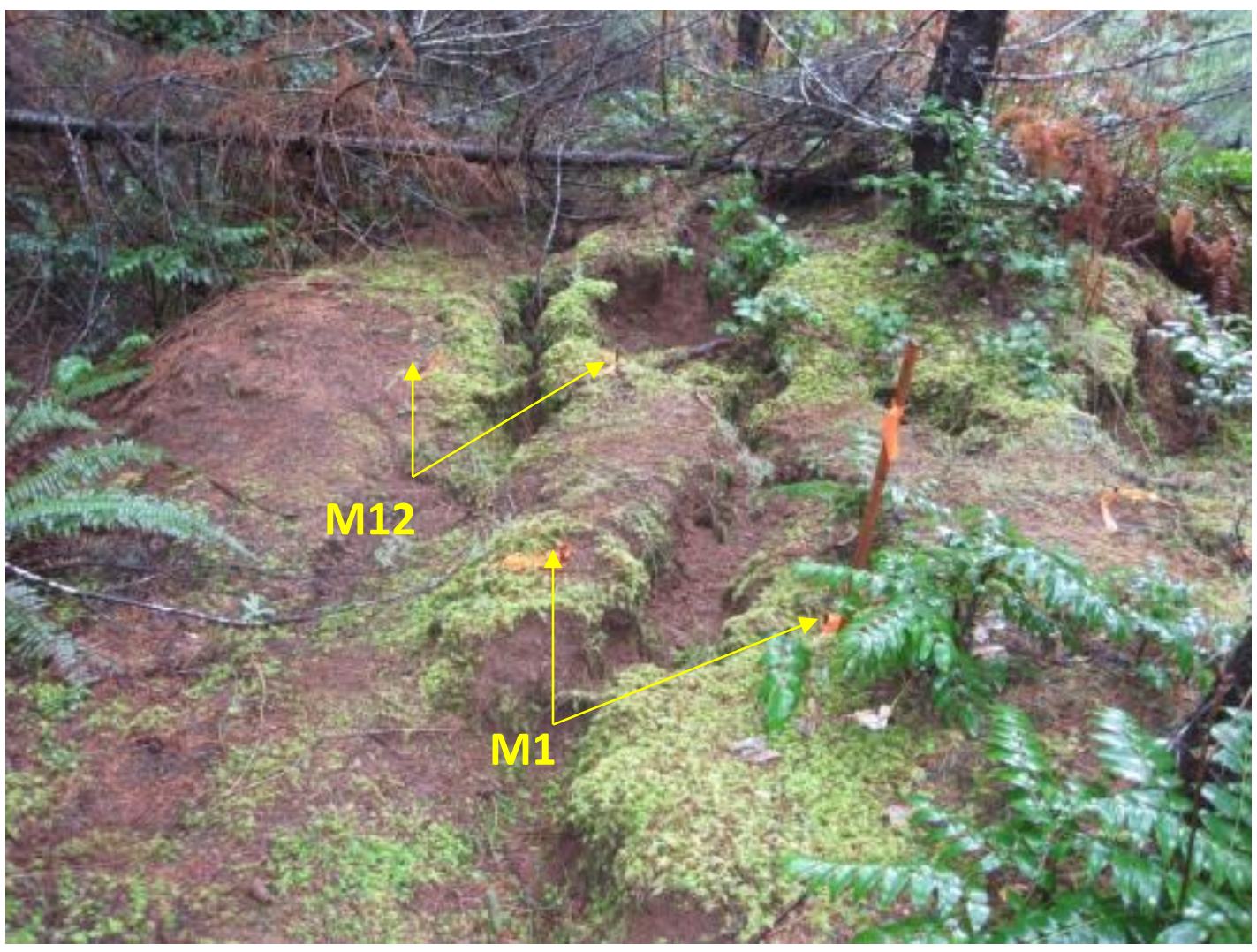

Figure 3-1. Photo of the ground cracks observed in the upper landslide. Foreground shows crack monitoring stations $\mathrm{M} 1$ and $\mathrm{M} 12$, looking northeast. The $0.6 \mathrm{~m}$ rebar rods are driven into the ground and marked with orange flagging. The distance between the two rods at each station was measured periodically.

If the landslide is moving, the distance between crack monitors will increase from extension, and the direction magnitude of movement can be recorded (Wieczorek and Snyder, 2009). Figure 3-2 presents the location of crack monitors in relation to ground cracks observed.

In addition, reference point stations were established with total station and GPS data collection. A high resolution Trimble GeoXH GPS unit was used to cross reference total station positions and to place the reference grid in geographic coordinates. All GPS measurements were post-processed with differential correction. Measurements of the 
grid points were completed during wet and dry climate periods over the approximately two years of field work.

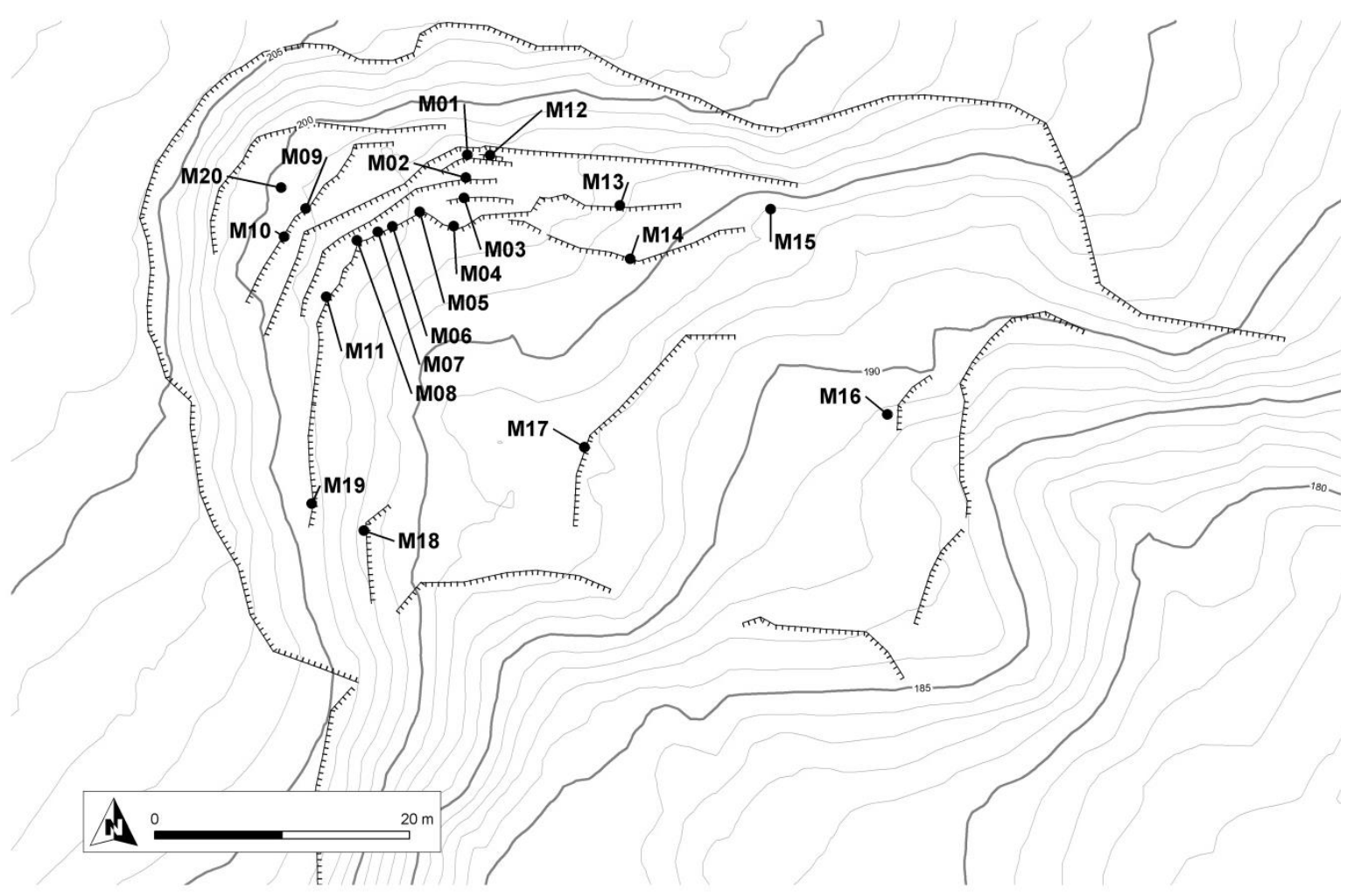

Figure 3-2. Location of crack monitoring points from the upper landslide area. Shows M1 through M20 crack monitoring locations as black dots and leader lines to labels with the measurement station identification. Ground cracks are shown as hash-marked black lines.

Creep monitoring data collected over the course of monitoring were evaluated with summary statistics. The mean, standard deviation, and variance were determined to identity potential errors in monitoring measurements (Davis, 2002).

\subsection{Soil Sample Collection}

Disturbed soil samples were collected from hand augered borings and soil pits for laboratory analysis (Cornforth, 2005). Sample locations are presented on Figure 3-3. 
The physical characteristics of the soil materials encountered were noted in the field.

Samples were tested for moisture content by ASTM D4959 - 07, Atterberg Limits by ASTM D4318-10, and sand size distribution by ASTM D1140-14 to assist in the soil classification. Four relatively undisturbed samples were collected from three locations in the landslide deposit and one sample was collected from outside the landslide terrain (Figure 3-3). The undisturbed samples were collected by driving a $6.4 \mathrm{~cm}$ diameter Shelby Tube 30 to $46 \mathrm{~cm}$ below ground after the surface was cleared of organic material. Undisturbed soil samples were tested for dry density (ASTM D7263-09).

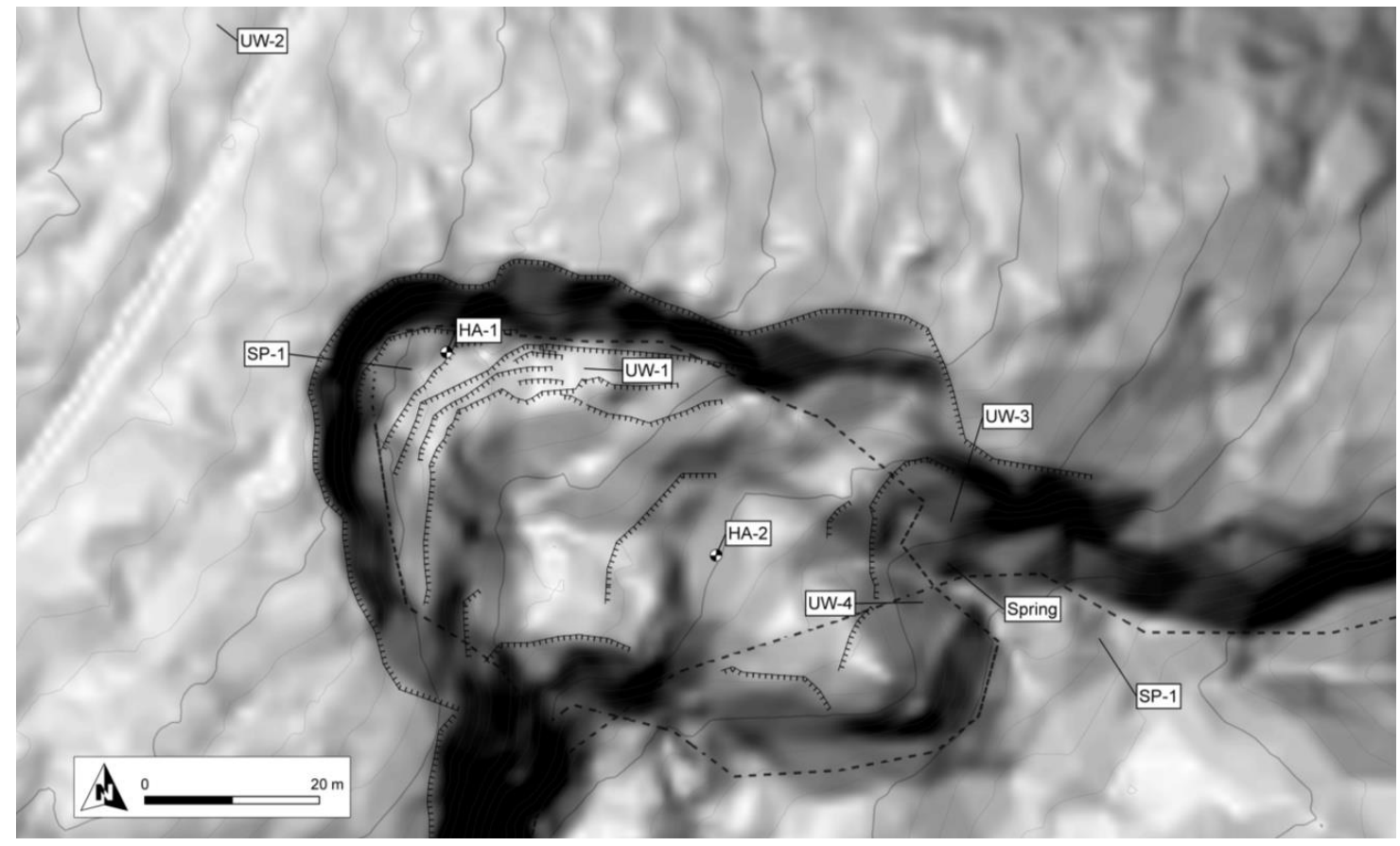

Figure 3-3. Location of soil sample collection points from the upper landslide area. Shows hand augers (HA-1 and HA-2), soil pits (SP-1 and SP-2), and undisturbed samples (UW-1, 2, 3, and 4) locations. 


\subsection{Laboratory Analysis of Soil Samples}

Soil samples collected in the field were processed in the soil laboratory. Samples

were selected for geotechnical soil properties analysis to characterize the soil mass of the landslide and to provide physical parameters to be used in the slope stability modeling.

\subsubsection{Atterberg Limits}

The Atterberg Limits test is used to determine the plastic and liquid limit and the resulting plasticity index of a soil. This test is used to measure the water content of the soil at certain points that control the deformation behavior of that soil. A cohesive soil will change from nonplastic behavior to plastic behavior to viscous behavior as the water content increases (Johnson and DeGraff, 1988). The ASTM D4318 (2010) approach was used for the Atterberg tests. The liquid limit (LL) is the percent water content where soil (in a standard Casagrande cup that is cut by a grooving tool of standard dimensions) will flow together at the base of the groove for a distance of 13 $\mathrm{mm}(1 / 2 \mathrm{in}$.$) when subjected to 25$ shocks from the cup being dropped $10 \mathrm{~mm}$ at a rate of two drops per second. The plastic limit (PL) is the water content, in percent, at which a soil can no longer be deformed by rolling into $3.2 \mathrm{~mm}(1 / 8 \mathrm{in}$.$) diameter threads$ without crumbling.

\subsubsection{Dry Unit Weight}

Relatively undisturbed samples were collected by driving a thin-walled cylinder (Shelby Tube type) into the underlying soil (ASTM D 2937-00). This test was conducted to determine the in-place density of undisturbed soil. The moist unit weight is when the 
pore space of the soil is partially filled with water and is the weight of moist soil per unit volume of soil. The dry unit weight of the soil when the pores are filled with air per unit volume of soil. Sample collection for dry unit weight was completed at four locations as shown on Figure 3-3.

\subsubsection{Direct Shear}

Direct shear testing was completed on a nearby landslide of similar geology. The landslide is located at latitude 45.216947/ longitude -123.45496, approximately $13 \mathrm{~km}$ southwest from the Madrone Landslide (latitude 45.298314/ longitude -123.338652). Undisturbed samples were collected from the shear plane of the landslide. (Undisturbed samples from the shear plane of the Madrone Landslide could not be collected with the instrumentation and tools available at the time.) The landslide is failing in the parent material mapped as the Nestucca Formation. The Yamhill Formation and the Nestucca Formation have very similar lithologies and depositional environments and can be difficult to distinguish in the field. Adjoining geologic map boundaries to the south of the Madrone Landslide from Wells et al. (1994) and Yeats et al. (1996) show some discrepancies in geologic mapping. At the map boundary, Wells et al. (1994) maps Yamhill Formation to the north while Yeats maps the unit as the Nestucca Formation to the south. Based on the similarities of the two geologic units and the lack of shear plane samples in the Madrone, the results from direct shear testing of the landslide shear plane in the Nestucca Formation were used for slope stability modeling input for the Madrone Landslide. 
The approximate residual shear strength of two representative samples were determined using a direct shear device under consolidated and drained conditions. The test was performed in substantial conformance with ASTM D 3080. Each sample was pre-sheared to establish a plane of failure. The samples were then sheared at $0.5,1.0$, and 2.0 times the estimated effective overburden stress. The samples were repeatedly sheared at each stage of confining normal stress until a relatively constant value of residual shear strength was obtained.

\subsection{Slope Stability Modeling}

Data collected at the site were used for input into Slope/W slope stability software (Geo-Slope 2014). The software package utilizes standard slope stability models such as Ordinary Method, Bishop, Spencer, and Morgenstern-Price to evaluate and determine the slope factor of safety (FS) for static and seismic loading conditions. The Morgenstern-Price method was selected for modeling slope stability at the Madrone Landslide (Morgenstern and Price, 1965).

I prefer the Morgenstern-Price method because it satisfies both force and moment equilibrium and uses a selected interslice force function. SLOPE/W uses the "General Limit Equilibrium" solution scheme to find the lambda value that results in the same factor of safety for both moment and force equilibrium. Interslice shear and normal forces are considered and the interslice shear forces are computed using the equation:

$$
X=E \lambda f(x)
$$


Where, $f(x)$ is an interslice force function, $\lambda$ is the percentage (in decimal form) of the function used, $\mathrm{E}$ is the interslice normal force and $\mathrm{X}$ is the interslice shear force.

By default, a total of 11 lambda values ranging from -1.0 to 1.0 are used in the solution. For each lambda value, SLOPE/W computes the factor of safety by moment equilibrium and force equilibrium. SLOPE/W finds the intersection point of the two lines to determine the converged FS and the converged lambda value.

\subsection{Multi-temporal Lidar Data Analysis}

Lidar data in the Panther Creek Watershed were acquired and processed by Watershed Sciences, Inc. (WSI). The lidar area of interest for WSI totals approximately 5,580 acres. Real-time kinematic (RTK) surveys were conducted in the study area for quality assurance purposes. The accuracy of the lidar data is described as standard deviations of divergence (sigma $\sim \sigma$ ) from RTK ground survey points and root mean square error (RMSE). The RMSE of the data were $0.04 \mathrm{~m}$ and 1 and 2 -sigma deviation was $0.04 \mathrm{~m}$ and $0.07 \mathrm{~m}$, respectively, on flat, hard ground with no vegetation. The RMSE are for well defined, easily identifiable locations and represent the best case scenario. Errors at the Madrone Landslide site are likely higher due to dense vegetation and steep terrain at the study site. The ground pulse density was 0.76 points per square meter while the total pulse density was 8.91 points per square meter. Following data collection, kinematic corrections for aircraft position data were completed using kinematic aircraft GNSS and RTK QA/QC GNSS data. Laser point positions were then 
calculated by associating the position to each laser point return time, scan angle, and intensity, and a raw laser point cloud was created for the entire survey area.

Burns et al. (2010) evaluated the lidar data and found the identification of landslide topography was limited by young forest and dense canopy. Based on the analysis of WSI lidar data, Burns et al. (2010) assigned an overall RMSE of $0.50 \mathrm{~m}$, a maximum error of $2.21 \mathrm{~m}$, and a systematic error of $0.09 \mathrm{~m}$. The RMSE of $0.50 \mathrm{~m}$ represents a more likely error than the lidar data as a whole.

The study of the Madrone Landslide followed an approach similar to Burns et al. (2010) in evaluating the elevation changes between lidar data sets. Lidar derived DEMs were generated from lidar point cloud data provided by the BLM. Lidar data were collected on the following flight dates:

- September 3, 2007, leaf-on

- December 8, 2007, leaf-off

- March 29, 2009, leaf-on

- July 15, 2010, leaf-on

- April 17, 2011, leaf-on

- April 27, 2012, leaf-on

Pairs of DEMs from consecutive years were subtracted from each other to generate a DEM of Difference (DoD). Based on the results from Burns et al. (2010) a threshold value of $0.5 \mathrm{~m}$ was applied to the DoD. This value was determined between leaf-on and leaf-off conditions and the threshold evaluation between leaf-off and leaf-off conditions, as completed in this study, would be less than $0.5 \mathrm{~m}$ but was used as a conservative approach. This threshold removed changes in elevation between 0.5 and - 
$0.5 \mathrm{~m}$ considered to be noise or areas with widespread contiguous elevation changes.

Following the application of the threshold, DEMs were reclassified to remove areas where elevation changes within the threshold values occurred. These data were then multiplied by the DoD for the lidar data pair. The final product produced a DEM with areas that had elevation changes greater than $\pm 0.5 \mathrm{~m}$. 


\section{CHAPTER 4 Results}

\subsection{Field Developed Cross Section}

The development of the cross section was completed to identify important landslide features including: the main headscarp, estimated failure surface, hand auger locations, extent of landslide debris, and springs observed during field work. The cross section was utilized to determine the estimated length of the failure zone, estimated thickness of the landslide debris, and an estimated slope gradient of the hillside. Multiple ground cracks were mapped on the upper landslide. No ground cracks were observed within the lower landslide. The field developed cross-section is presented on Figure 4-1. The figure shows the estimated outline of the landslide deposits for the upper and lower landslide as a dashed line. The hand augers were used to provide the majority of subsurface data. During field work, a topographic depression was observed south of the upper landslide in the area mapped as the lower landslide.

The upper landslide is a classic, rotational earth slump with indications of hyper concentrated flow at the toe. The hyper concentrated flow was observed as a flat unvegetated area with exposed debris originating from the Yamhill Formation that appeared washed of finer material. The upper landslide has an area of 2,700 $\mathrm{m}^{2}$. The headscarp for the upper landslide ranges from approximately $5 \mathrm{~m}$ to $7 \mathrm{~m}$. The depth to the failure plane in the upper landslide is estimated to be approximately $6 \mathrm{~m}$. A rough estimate of volume is approximately $15,700 \mathrm{~m}^{3}$. The head scarp of the upper landslide consists of exposed soil and is generally unvegetated and steep. Ground cracks are 
sharp and also unvegetated. Based on the morphology, the upper landslide could be considered an active-young landslide (McCalpin, 1984). 

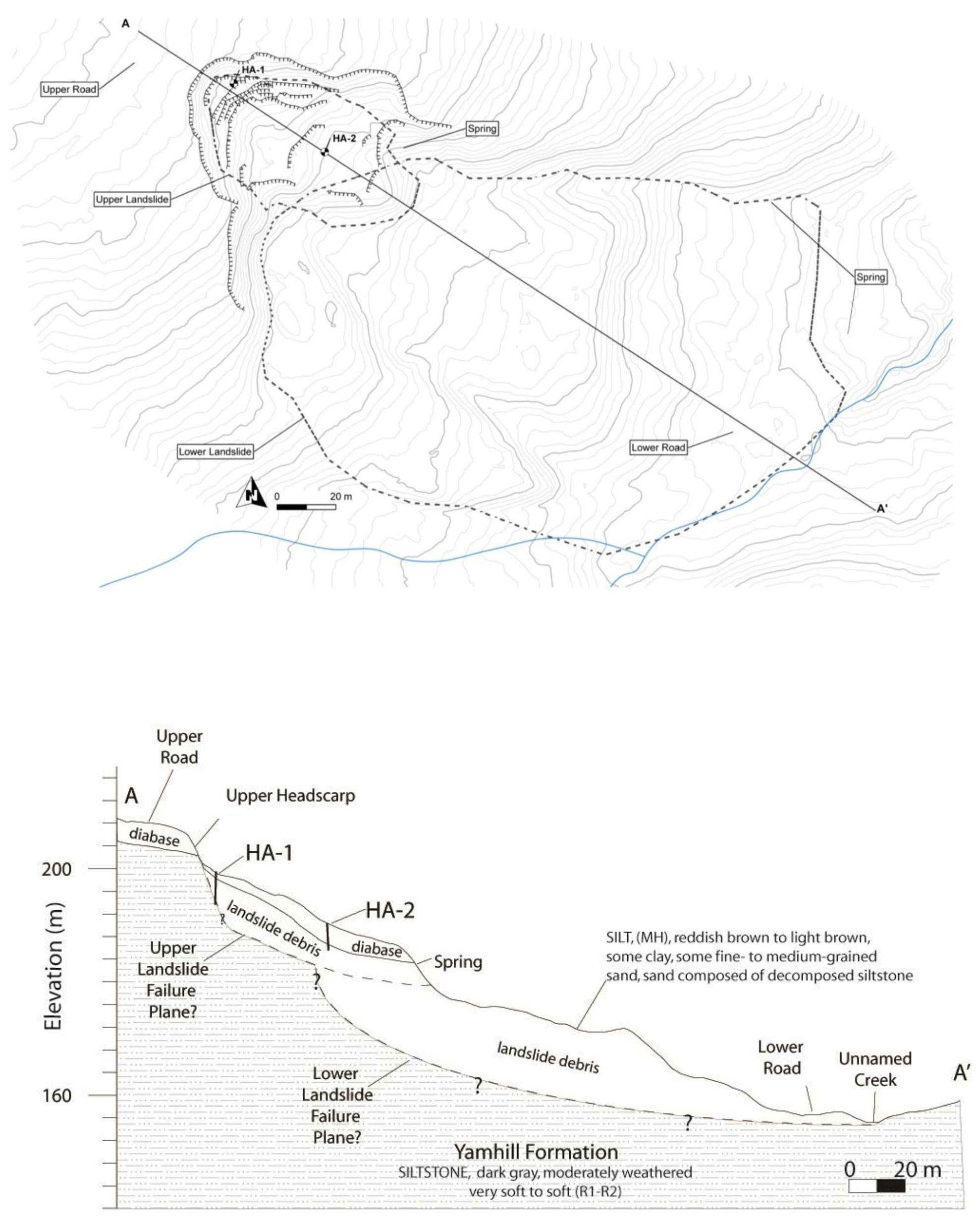

Figure 4-1. Field developed cross-section of the Madrone Landslide. A) Site plan and topography of the landslide showing the upper and lower landslide sections. Mapped head scarp and multiple internal scarps are presented as lines with hatch marks pointing downhill. Cross section line A to $\mathrm{A}^{\prime}$ shown in B. B) Cross section of the Madrone Landslide. Failure planes and landslide debris thickness estimated from geomorphology interpretation of the surface terrain. 
Based on a comparison of the morphology, the lower landslide appears to be an earth flow. The lower landslide has an area of approximately $23,000 \mathrm{~m}^{2}$ and an approximate scarp height of $15 \mathrm{~m}$. The depth to the failure plane is estimated to be approximately $12.5 \mathrm{~m}$. A rough estimate of volume is approximately $287,500 \mathrm{~m}^{3}$. The lower landslide has subdued topography (hummocks have eroded down), and stream tributaries (seasonal) are establishing along the lateral margins of the landslide. The lower landslide would likely classify as a dormant-mature landslide (McCalpin, 1984).

\subsection{Geologic Mapping}

Geologic mapping of the area by Wells et al. (1994) shows the Yamhill Formation at the site. Geologic mapping of the site for this study indicates that an approximately one to two meter mantle of weathered diabase overlies the Yamhill Formation. A geologic map produced from the field survey is shown on Figure 4-2.

Exposed diabase in the landslide headscarp and scarp flank areas is a predominantly decomposed (rock mass is more than $50 \%$ decomposed, complete discoloration, surface is friable and pitted) to decomposed rock. Some portions observed exhibited relict rock structure, and it readily disaggregates when disturbed. Some portions of the weathered rock in the headscarp exhibits spheroidal weathering with various weathered rind thicknesses. Hand sample evaluation shows an aphyric to plagioclase-phyric mafic volcanic rock. Spheroidal weathering of the diabase produces abundant coarse sand to gravel sized nodules. 


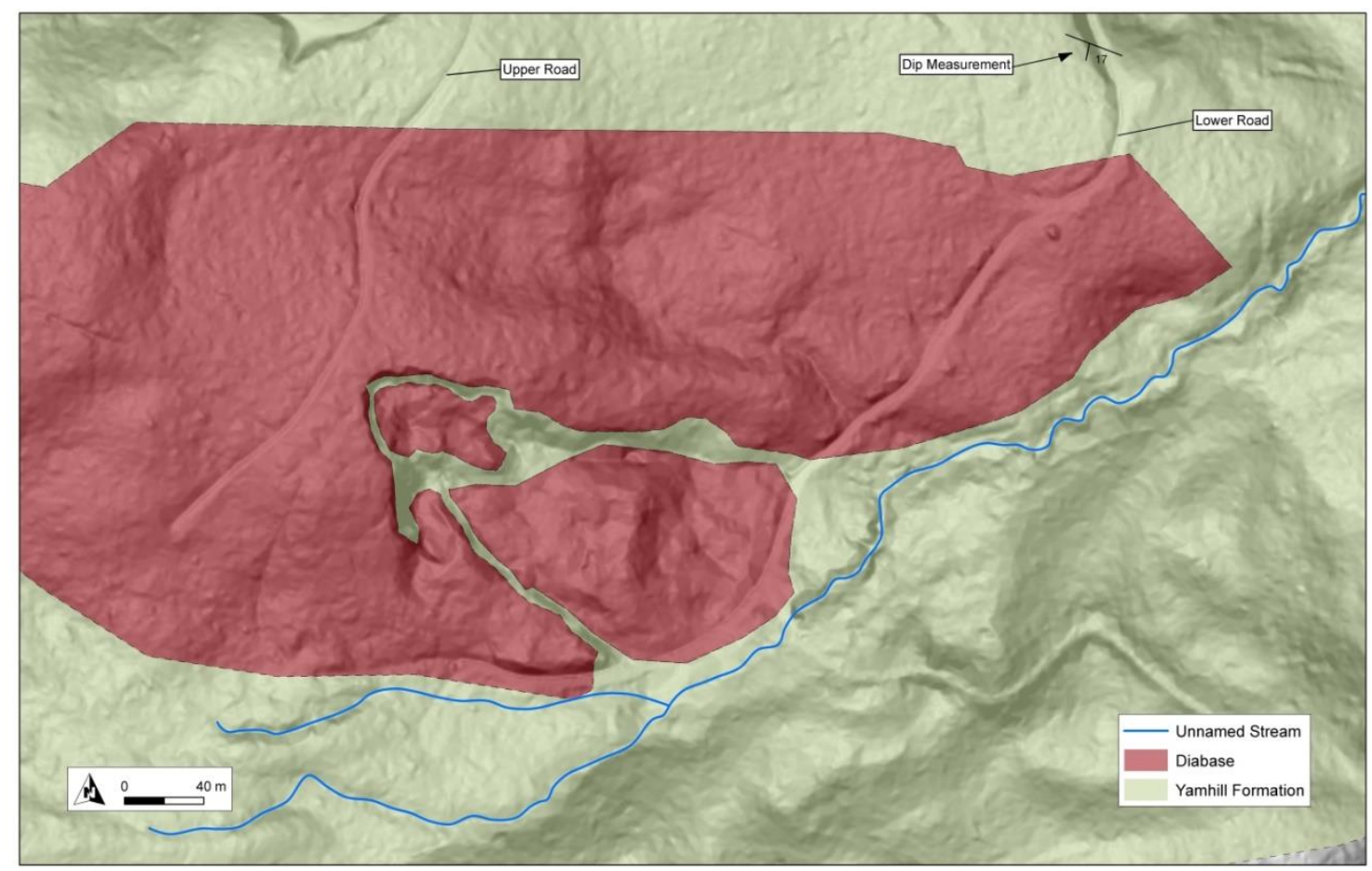

Figure 4-2. Geologic map showing the extent of observed geologic units at the project site. Diabase of Lee's Falls (red) is located over the surface mantling the Yamhill Formation (Tan) below. Location of strike and dip collected in the northeast corner of the map.

Less weathered fragments of diabase collected from the headscarp typically have a 3 to $4 \mathrm{~mm}$ thick weathering rind. The diabase parent material weathers to a red $(2.5 \mathrm{YR} 4 / 6)$ clayey silt soil observed in the headscarp and scarp flanks. This distinctive red soil was used to identify weathered diabase at the ground surface where not exposed by the landslide. The Yamhill County Soil Survey indicates the entire area of the Madrone Landslide is identified as the Hembre silt loam on 3 to 30 percent slopes which is listed as fine-loamy, mixed, mesic Andic Haplumbrept (Otte et al. 1974). 


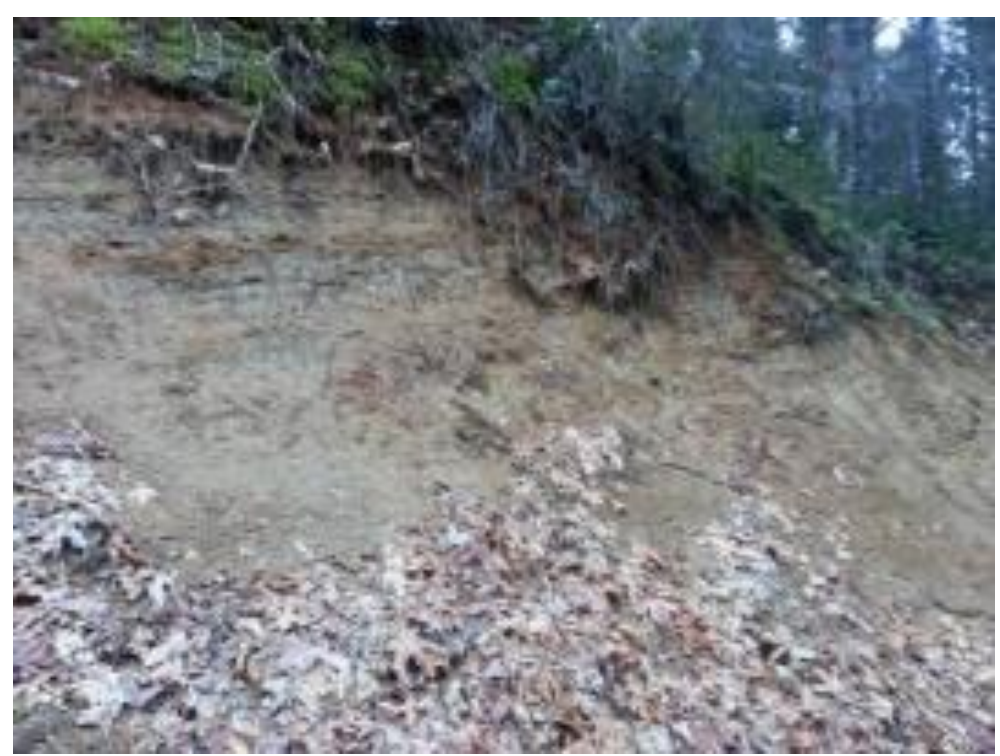

Figure 4-3. Photograph of the outcrop north of the Madrone Landslide that was used to determine the bedding orientation of the Yamhill Formation. Looking north-northwest the bedding appears to be striking approximately $280^{\circ}$ and dipping approximately $17^{\circ}$ to the southwest.
The Yamhill

Formation is exposed

underlying the diabase in

the headscarp and scarp

flanks and consists of a

predominantly

decomposed siltstone.

The Yamhill Formation

weathers to a pale brown

soil with rust mottling.

Weathering of the

Yamhill Formation produces a lighter colored brown (10YR 7/4) soil compared to the dark red soil that the diabase produced. The observation of the soil characteristics produced by the weathering of the Yamhill Formation assisted in the identification of subsurface geologic material where the geologic unit was not exposed. The Yamhill Formation was observed exposed at several locations in the vicinity of the Madrone Landslide that did not appear to be disturbed by landslide processes. Along the entrance road from Von Road past the security gate the access road cuts into the Yamhill Formation and exposes bedding planes. The orientation of the bedding was measured with a Brunton compass at a strike of $280^{\circ}$ and a dip of $17^{\circ}$ to the southwest into the slope (Figure 4-2). 


\subsection{Precipitation Data Collection}

Annual cumulative precipitation data from the Haskins Dam meteorological (MET) station are plotted in Figure 4-4 from 1995 to 2013, a period of 18 years. Average annual cumulative precipitation is $1,976 \mathrm{~mm}$ (78 in.) per year. The highest annual cumulative precipitation was in $1996(2,932 \mathrm{~mm})$ and the lowest was in $2013(1,240$

$\mathrm{mm}$ ). Since 2007, when lidar data collection began, annual cumulative precipitation has been below average with the exception of 2010 and 2012. Precipitation data for 2013 indicates it was the driest year in over 20 years of recorded data at the Haskins Dam station.

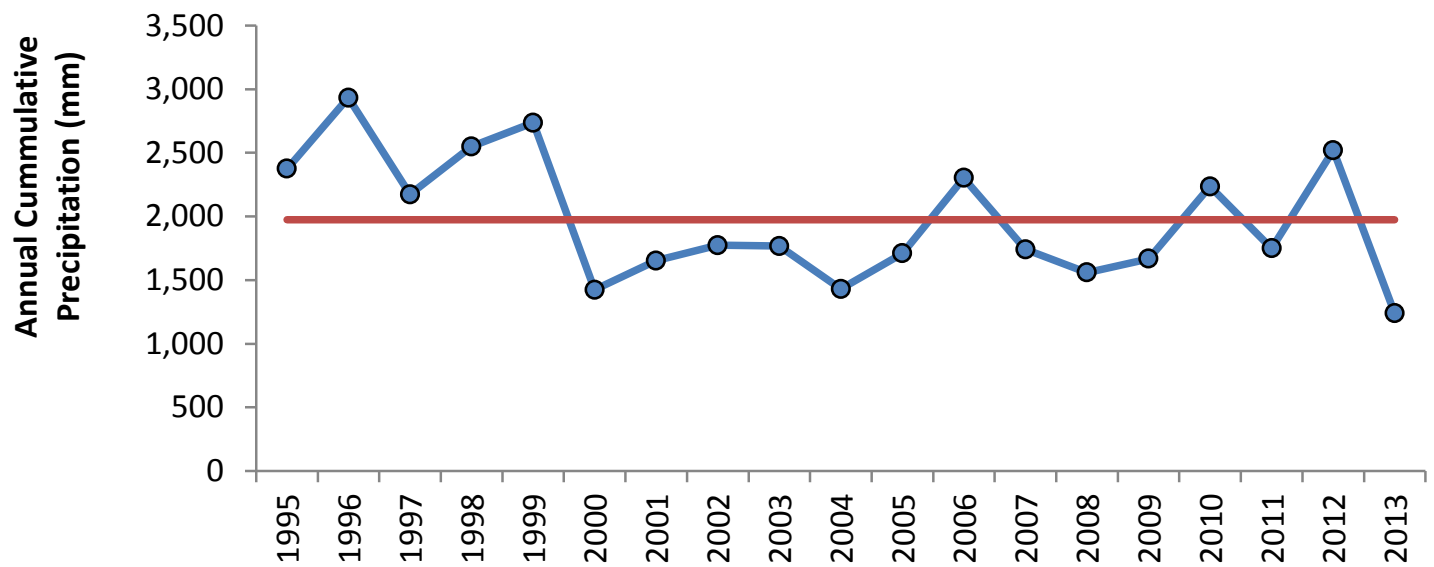

Figure 4-4. Annual cumulative precipitation from 1995 to 2013. Average annual cumulative precipitation for this time period is $1,975 \mathrm{~mm}$. The wettest year for precipitation occurred in 1996 with 2,932 $\mathrm{mm}$. Lidar data collection begins in September 2007, a below average year for precipitation. Field instrumentation on the Madrone Landslide was installed in Aug 2012 and continued to May 2014. The driest year in the period presented occurred in 2013.

Table 4-1 presents statistical summary of daily precipitation from 1995 to 2013 for each year and for all years. Table 4-1 shows that average peak daily precipitation for the 18 year period is $100 \mathrm{~mm}$. While 10 out of the 18 years of record show above average 
peak daily precipitation, four storms are notable for intensity and impact to the public and infrastructure. Four major storms that produced significant rainfall and declared major disasters by FEMA occurred in 1996, 2007, 2009, and 2012. 


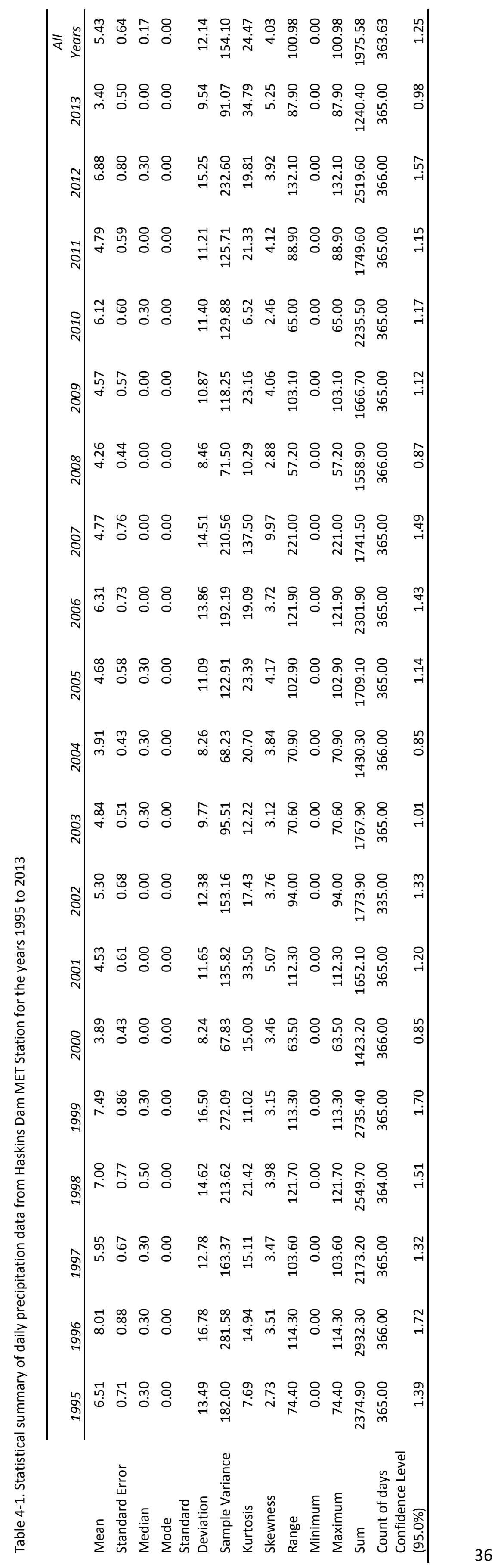


The event in 1996 produced widespread flooding in the Portland Metro area and has the highest annual cumulative precipitation of 2,932 $\mathrm{mm}$ but only slightly above average daily rainfall peak, $114 \mathrm{~mm}$. A total of 705 landslides were recorded in the Portland area alone (Burns, 1998).

Three storms of above average precipitation events exceeding $100 \mathrm{~mm}$ of precipitation occurred over the course of lidar data collection: December 3, 2007 (221 mm), January 2, 2009 (103 mm), and November 19, 2012 (132 mm). While 2007 shows a below average annual cumulative precipitation $(1,742 \mathrm{~mm})$ and the highest daily peak (221 $\mathrm{mm})$, this storm event was also followed by widespread flooding and severe wind damage.

On December 3, 2007, approximately $221 \mathrm{~mm}$ of rain was recorded at the Haskins Dam MET station. This particular storm, also known as an atmospheric river event (Zhu and Newell, 1998), caused severe damage across Oregon and Washington. Wind gusts over 161 kilometers per hour were recorded along the Oregon coast (Wolf, 2007). Flooding, hundreds of debris flows, and 13 fatalities were recorded following the storm (Oregonian, 2007). Figure 4-5 presents base reflectivity data from the NEXRAD Doppler radar for December 3, 2007 and illustrates intense rainfall over the Madrone study area. The rainfall on December 3rd was $121 \mathrm{~mm}$ above the average daily peak rainfall for the 18 year period, but $234 \mathrm{~mm}$ below the average annual cumulative precipitation. Two weeks prior to December 3rd, zero precipitation was recorded. One week prior to 
December $3 \mathrm{rd}$, precipitation ranged from 0.3 to $46.5 \mathrm{~mm}$. The high end of this range was on December 2, 2007. 


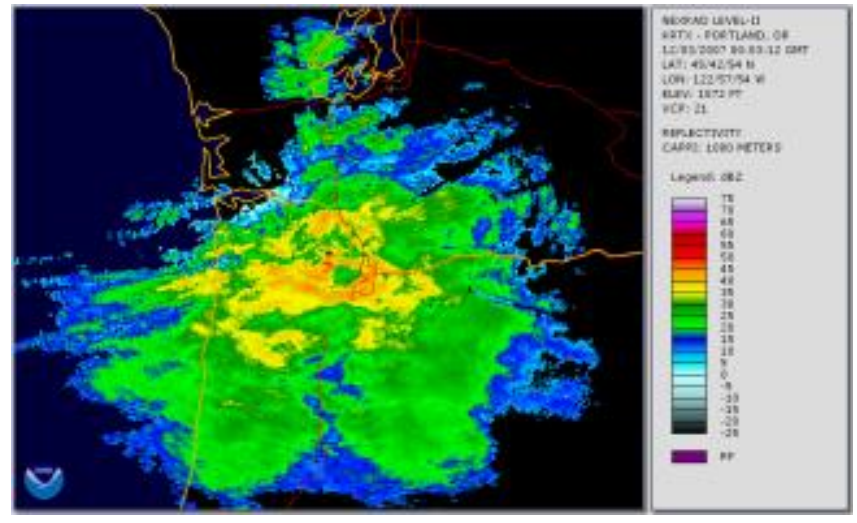

Figure 4-5. NEXRAD short range base reflectivity data for the December 3, 2007 atmospheric river event. Image is for just after midnight GMT.
On January 2, 2009, strong

winds and heavy rain moved on

shore and soaked the western

portion of Oregon. Some parts

received 100 to $130 \mathrm{~mm}$ of rain in

24 hours. The heavy rainfall

combined with snowmelt runoff

caused flooding along multiple rivers in northwest Oregon. The heavy rain caused a landslide which collapsed a portion of Highway 22 near the town of Grande Ronde approximately $30 \mathrm{~km}$ from the Madrone Landslide. Rainfall accumulation at the Haskins Dam MET station was $103 \mathrm{~mm}$. The 2009 cumulative annual rainfall of 1,666 mm was $308 \mathrm{~mm}$ below average for the 1995-2013 period.

Record breaking rainfall occurred from November 19th-21st 2012 due to an atmospheric river event that caused flooding in many counties. Rainfall totals of over $132 \mathrm{~mm}$ were recorded. Multiple cars were damaged by falling trees and mudslides associated with this storm. Thousands of people were out of power in both Washington and Oregon. The 2012 cumulative annual rainfall of 2,520 $\mathrm{mm}$ was $544 \mathrm{~mm}$ above average for the 1995-2013 period. 


\subsection{Historical Aerial Photographs}

Historical aerial photographs of the site were obtained from the University of

Oregon Map Library. Aerial photographs for the years 1948, 1953, 1956, 1963, 1970,

1980, 1988, 1993, 1995, 2000, 2003, 2005, 2008, 2009, and 2012 were examined. Copies

of the aerial photographs are included in the Appendix. Observations are listed below.

1948 The 1948 historical aerial photograph shows that the area of the Madrone Landslide appears to have been harvested for timber. Several tall trees are isolated and casting shadows on shorter vegetation. The lower road is visible along the south east corner of the photo. There are no apparent headscarps or other typical landslide topographic features visible in the photograph.

1953 No significant changes are evident from the previous aerial photograph.

1956 No significant changes are evident from the previous aerial photograph.

1963 The lower road has been extended and is visible cutting up to the southwest of the Madrone Landslide. A potential headscarp may have formed for the lower landslide. However, the quality of the photo makes definitive determination difficult.

1970 No significant changes are evident from the previous aerial photograph. The potential headscarp observed on the 1963 aerial photograph is not completely obvious on the 1970 aerial photograph.

1980 No significant changes are evident from the previous aerial photograph.

1988 No significant changes are evident from the previous aerial photograph.

1993 The 1993 aerial photograph shows earthwork activity along the lower road with changes in the width of the lower road. In addition, the upper road has been constructed. The potential headscarp from the 1963 aerial photograph is subtle if present.

1995 The poor quality of the photograph makes identification of the lower landslide headscarp difficult. 
2000 The area appears to have been harvested for timber. The headscarp of the lower portion of the landslide can be potentially observed, however, photo quality is poor.

2003 The headscarp of the lower landslide is clearly visible. The headscarp for the upper landslide is not visible.

2005 No significant changes are evident from the previous aerial photograph. The headscarp of the lower landslide is plainly visible.

2008 A headscarp may be visible in the 2008 aerial photograph. There appears to be some change in the characteristic of the upper landslide. Photo quality is poor.

2009 The headscarp in the upper landslide is plainly visible. Exposed soil at the headscarp of the upper landslide and lower landslide can be observed on the photograph.

2012 No significant changes are evident from the previous aerial photograph.

The vicinity of the Madrone Landslide appears to have been harvested for timber in 1948. A potential landslide scarp appears visible in the 1963. Timber harvest is evident on the 2000 aerial photograph. The lower landslide headscarp appears visible in the 2000. The upper landslide headscarp appears visible in the 2009 aerial photograph.

\subsection{Ground Crack Monitoring}

Ground crack monitoring locations for the 20 measurement stations are presented on Figure 3-2. Measurements were collected five times during access to the field site. Some minor variation in the recorded data can be observed. While care was exercised to reduce measurement error, different tape measures were used, and measurements were not collected in the same direction. Values of distance were recorded from the edge of one rod the same outside edge of the paired rod. 
Table 4-2. Summary of measurements completed at creep monitoring stations. Values are in inches.

\begin{tabular}{lrrrrr}
\hline & $\mathbf{1 / 5 / 2 0 1 3}$ & $\mathbf{5 / 1 0 / 2 0 1 3}$ & $\mathbf{6 / 3 0 / 2 0 1 3}$ & $\mathbf{1 0 / 6 / 2 0 1 3}$ & $\mathbf{3 / 9 / 2 0 1 4}$ \\
\hline M1 & 24 & 23.875 & 23.8125 & 23.9375 & 23.875 \\
M2 & 20.875 & 20.75 & 20.9375 & 20.75 & 20.75 \\
M3 & 37.625 & 37.25 & 37.625 & 37.5 & 37.25 \\
M4 & 39.875 & 39.75 & 39.8125 & 39.75 & 39.875 \\
M5 & 48.875 & 48.875 & 48.75 & 48.875 & 48.875 \\
M6 & 16.875 & 16.75 & 16.75 & 16.75 & 16.75 \\
M7 & 45 & 44.75 & 44.875 & 44.875 & 44.75 \\
M8 & 36.375 & 36.125 & 36.375 & 36.375 & 36.125 \\
M9 & 41.875 & 41.625 & 41.625 & 41.625 & 41.625 \\
M10 & 31.75 & 31.125 & 31.5 & 31.5 & 31.125 \\
M11 & 34.5 & 34.5 & 34.125 & 34.125 & 34.125 \\
M12 & 27.5 & 27.375 & 27.125 & 27.125 & 27.375 \\
M13 & 44.375 & 44.125 & 44.125 & 44.5 & 44.125 \\
M14 & 43.375 & 43.125 & 43.125 & 43.125 & 43.125 \\
M15 & 45.75 & 45.25 & 45.5 & 45.375 & 45.25 \\
M16 & 39.5 & 39.125 & 39.125 & 40 & 39.125 \\
M17 & 24.375 & 24.375 & 24.125 & 24.5 & 24.5 \\
M18 & 45.375 & 45.125 & 45.25 & 45.125 & 45.125 \\
M19 & 33.875 & 33.125 & 33.625 & 33.4375 & 33.125 \\
M20 & 35.125 & 33.875 & 34.75 & 34.75 & 34.125 \\
\hline
\end{tabular}

The rebar rods exhibited slightly different shapes at the top of the rod originating from differences in the manufacturing process. Depending on the direction the measurement was taken, a small lip of metal at the top of the rod may be reflected in the measurement from one direction but not the other direction. The small variations in measurements are likely the result of the difference in measurement tapes and measurement procedure.

Table 4-3 presents summary statistics for the crack monitoring measurements. The statistical analysis of the crack monitoring measurements shows that, with a few exceptions, the majority of crack measurements have standard deviations less than 0.5 inch. As presented on Table 4-3, standard deviations greater than 0.25 in. were 
recorded at monitoring stations $\mathrm{M} 10, \mathrm{M} 16, \mathrm{M} 19$, and $\mathrm{M} 20$. All measurements for the year of recording were approximately equal and did not appear to increase significantly indicating no landslide movement was observed in the crack monitoring measurements.

Table 4-3. Summary statistics for creep measurements.

\begin{tabular}{|c|c|c|c|c|c|}
\hline & Mean & Median & $\begin{array}{l}\text { Standard } \\
\text { Deviation }\end{array}$ & Variance & Standard Error \\
\hline M1 & 23.900 & 23.875 & 0.071 & 0.005 & 0.032 \\
\hline M2 & 20.813 & 20.750 & 0.088 & 0.008 & 0.040 \\
\hline M3 & 37.450 & 37.500 & 0.190 & 0.036 & 0.085 \\
\hline M4 & 39.813 & 39.813 & 0.063 & 0.004 & 0.028 \\
\hline M5 & 48.850 & 48.875 & 0.056 & 0.003 & 0.025 \\
\hline M6 & 16.775 & 16.750 & 0.056 & 0.003 & 0.025 \\
\hline M7 & 44.850 & 44.875 & 0.105 & 0.011 & 0.047 \\
\hline M8 & 36.275 & 36.375 & 0.137 & 0.019 & 0.061 \\
\hline M9 & 41.675 & 41.625 & 0.112 & 0.013 & 0.050 \\
\hline M10 & 31.400 & 31.500 & 0.271 & 0.073 & 0.121 \\
\hline M11 & 34.275 & 34.125 & 0.205 & 0.042 & 0.092 \\
\hline M12 & 27.300 & 27.375 & 0.168 & 0.028 & 0.075 \\
\hline M13 & 44.250 & 44.125 & 0.177 & 0.031 & 0.079 \\
\hline M14 & 43.175 & 43.125 & 0.112 & 0.013 & 0.050 \\
\hline M15 & 45.425 & 45.375 & 0.209 & 0.044 & 0.094 \\
\hline M16 & 39.375 & 39.125 & 0.385 & 0.148 & 0.172 \\
\hline M17 & 24.375 & 24.375 & 0.153 & 0.023 & 0.068 \\
\hline M18 & 45.200 & 45.125 & 0.112 & 0.013 & 0.050 \\
\hline M19 & 33.438 & 33.438 & 0.325 & 0.105 & 0.145 \\
\hline M20 & 34.525 & 34.750 & 0.511 & 0.261 & 0.228 \\
\hline
\end{tabular}

\subsection{Soil Sample Collection}

Subsurface materials and conditions were investigated with two hand-auger borings, designated HA-1 and HA-2, two hand dug soil pits designated SP-1 and SP-2, and four near surface undisturbed samples. Hand augers HA-1 and HA-2 were advanced to depth of $3.9 \mathrm{~m}$ and $4.5 \mathrm{~m}$, respectively at the approximate locations shown on Figure 3-3; Table 4-4. 
Two material types were encountered in the hand auger borings, soil pits, and relatively undisturbed samples. Surface soil consisted of silt, brown to reddish brown, with some clay, trace fine- to medium- grained sand. Underlying the reddish brown silt is a light brown to tan silt, with some clay to clayey, and fine- to coarse- grained sand sized fragments of friable siltstone.

During hand auger

investigation in March 2014,

groundwater was encountered at

a depth of $2.6 \mathrm{~m}$ in hand auger

HA-1 and a depth of $3 \mathrm{~m}$ in hand

auger HA-2. By May 2014, the

groundwater depth had increased

to a depth of $3.8 \mathrm{~m}$ in hand auger

HA-1 and was not encountered at

the total depth of HA-2 at $4.5 \mathrm{~m}$.

These groundwater conditions

were used in the slope stability model discussed in Section 4.8.
Table 4-4. Soil sample moisture contents and percent passing P200 sieve for hand auger and soil pit locations. Test Sample Sample Moisture Passing Location Depth Content P200 Sieve (cm) (\%) (\%)

\begin{tabular}{lllll}
\hline \multirow{5}{*}{ SP-1 } & S-1 & 15 & 57 & 24 \\
& S-2 & 61 & 48 & 44 \\
& S-3 & 107 & 51 & 21 \\
& S-4 & 137 & 46 & 29 \\
\hline \multirow{3}{*}{ SP-2 } & S-1 & 31 & 113 & 31 \\
& S-2 & 91 & 42 & 16 \\
& S-3 & 152 & 55 & 24 \\
\hline \multirow{5}{*}{ HA-1 } & S-1 & 140 & 67 & 41 \\
& S-2 & 272 & 62 & 27 \\
& S-3 & 343 & 61 & 49 \\
& S-4 & 366 & 24 & 16 \\
\hline \multirow{5}{*}{ HA-2 } & S-1 & 15 & 43 & 12 \\
& S-2 & 81 & 21 & 26 \\
& S-3 & 163 & 45 & 9 \\
& S-4 & 305 & 45 & 12 \\
& S-5 & 366 & 53 & 10 \\
& S-6 & 452 & 47 & 51 \\
\hline
\end{tabular}

\subsection{Laboratory Analysis of Soil Samples}

To assist in classification of the soils, samples of known dry weight were washed over a No. 200 sieve. The material retained on the sieve was oven-dried and weighed, 
and the percentage of material passing the No. 200 sieve was calculated. The test results and natural moisture content is presented in Table 4-4.

\subsubsection{Atterberg Limits}

Atterberg limits were performed for six samples in conformance with ASTM D 4318 to determine the soil classification. The Atterberg test for sample S-4 collected from HA2 from material described a weathered diabase, yielded a plastic limit (PL) of 50\%, a liquid limit (LL) of 63\%, and a plasticity index (PI) of 13\%. Plotting the PI against the LL indicates the soil can be classified as an $\mathrm{MH}$ soil, or inorganic, high plasticity silt. The Atterberg test for a sample collected from an undisturbed sample, UW-4, yielded a plastic limit $(\mathrm{PL})$ of $64 \%$, a liquid limit (LL) of $73 \%$, and a plasticity index (PI) of $10 \%$. Plotting the PI against the LL indicates the soil can also be classified as an $\mathrm{MH}$ soil. This material is a weathered diabase material. Table 4-5 presents a summary of the results of Atterberg limit testing.

\begin{tabular}{|c|c|c|c|c|c|}
\hline Exploration & Sample & Liquid Limit (\%) & Plastic Limit (\%) & Plastic Index (\%) & Classification \\
\hline HA-1 & S-3 & 76 & 58 & 18 & $\mathrm{MH}$ \\
\hline $\mathrm{HA}-2$ & S-3 & 73 & 51 & 22 & $\mathrm{MH}$ \\
\hline $\mathrm{HA}-2$ & S-4 & 63 & 50 & 13 & $\mathrm{MH}$ \\
\hline $\mathrm{HA}-2$ & S-6 & 75 & 53 & 23 & $\mathrm{MH}$ \\
\hline UW-4 & NA & 73 & 64 & 10 & $\mathrm{MH}$ \\
\hline SP-2 & S-2 & 62 & 60 & 3 & $\mathrm{MH}$ \\
\hline
\end{tabular}

\subsubsection{Unit Weight and Shear Strength}

The dry unit weight of four undisturbed soil samples was determined in the laboratory. The approximate undrained shear strength of four relatively undisturbed samples of fine-grained soil was determined using a Torvane shear device. The Torvane is a hand-held apparatus with vanes which are inserted into the soil. The torque 
required to fail the soil in shear around the vanes is measured using a calibrated spring.

The unit weights ranged from 1.03 to $1.26 \mathrm{~g} / \mathrm{cm}^{3}$ and the shear strengths ranged from 0.2 to $0.25 \mathrm{~kg} / \mathrm{cm}^{2}$. The unit weight determination and results of the Torvane shear strength test is tabulated below, Table 4-6

\begin{tabular}{cccc}
$\begin{array}{c}\text { Table 4-6. Summary of Dry Unit Weight Determination } \\
\text { Natural Moisture } \\
\text { Sample } \\
\text { Content, \% }\end{array}$ & $\begin{array}{c}\text { Dryit } \\
\text { Weight, }\left(\mathbf{g} / \mathbf{c m}^{3}\right)\end{array}$ & $\begin{array}{c}\text { Torvane Shear } \\
\text { Strength }\left(\mathbf{k g} / \mathbf{c m}^{2}\right)\end{array}$ \\
\hline UW-1 & 34 & 1.19 & Not tested \\
UW-2 & 34 & 1.26 & 0.2 \\
UW-3 & 54 & 1.03 & 0.25 \\
UW-4 & 45 & 1.12 & 0.2 \\
\hline
\end{tabular}

\subsubsection{Direct Shear}

Undisturbed samples were collected from landslide material from the landslide located $13 \mathrm{~km}$ southwest of the Madrone landslide. As part of the investigation, the residual shear strength of two samples was determined for key parameters in slope stability modeling.

The geologic setting for the nearby project site is very similar to the geologic setting of the Madrone Landslide. The project is located in Yamhill County in the Coast Range of Oregon. The geologic material at the site is mantled with the same diabase unit observed at the Madrone Landslide. Underlying the diabase is the Nestucca Formation. The Nestucca Formation is a thin bedded, laminated dark gray tuffaceous mudstone with fine- to coarse-grained, graded arkosic and basaltic sandstone interbeds, locally glauconitic and fossiliferous, thin tuff beds and common calcareous concretions (Wells et al., 1994). Foraminifera of the Nestucca Formation are referred to upper Narizian 
stage while Yamhill Formation foraminifera are assignable to the lower Narizian (Wells et al., 1994). The two units are similar in age and both interpreted to be deep marine sedimentary units. This similarity is the basis for using results of direct shear testing for the Madrone Landslide modeling. The results of the direct shear strength tests are summarized in Table 4-7.

\begin{tabular}{|c|c|c|c|}
\hline Sample & Depth (ft) & $\begin{array}{c}\text { Residual } \\
\text { Friction Angle }\end{array}$ & Soil Type \\
\hline S-1 & 32 & $28^{\circ}$ & Clayey SILT \\
\hline $\mathrm{S}-2$ & 9 & $39^{\circ}$ & Silty CLAY \\
\hline
\end{tabular}

The shear strength of landslide debris was estimated based on the results of direct shear testing. Direct shear testing was performed on samples of landslide debris and weathered siltstone. The results of direct shear testing on landslide debris indicate a residual friction angle of $\phi^{\prime} r=28^{\circ}$ for a sample of clayey silt (S-1), and $\phi^{\prime} r=39^{\circ}$ for a sample of silty clay (S-2). Cohesion was estimated to be approximately $20 \mathrm{kPa}$ generally typical of MH soils.

The direct shear test results for weathered siltstone were used to estimate the shear strength of intact, relatively unweathered, siltstone. The angle of internal friction of undisturbed siltstone was determined using a calculation based on surface roughness of fractures, and the $\phi^{\prime} r=39^{\circ}$ was determined for sample S-2. Additionally, it was estimated that the cohesion $\left(c^{\prime}\right)=0$ for the fracture surfaces. 
The parameters determined by the direct shear testing and unit weight determination were used in the slope stability modeling for the Madrone Landslide.

\subsection{Slope Stability Modeling}

A slope stability analysis was performed to evaluate the stability conditions on the Madrone Landslide. All slope stability analyses presented are based on the subsurface geologic model presented in the field developed cross section and analyzed by the Morgenstern Price method. The upper landslide of the Madrone was selected for modeling as this portion of the landslide was the focus ground based measurements for this study. The stability of the upper and lower landslide combined was not evaluated.

Static stability analyses were performed for the 2-dimensional profile of the landslide as depicted in the field developed cross-section. The soil properties used for this modeling were determined using the results of laboratory testing and estimated values used where laboratory results were not available. Results of direct shear testing were used to estimate the residual friction angle for the landslide debris. The test results for weathered siltstone were also used to model intact, relatively unweathered siltstone.

Two groundwater conditions were evaluated for slope stability. The soil parameters were held fixed for the modeling and groundwater elevation adjusted to evaluate the pore water pressure needed to reduce the FS equal to about one $(F S=1)$. A factor of safety of one suggests that the ratio of the resisting forces (frictional forces) to the driving forces (forces acting down the slope along the failure plane) is approximately 
one. The low groundwater condition was established by measurements of groundwater depth in hand augers HA-1 and HA-2. The high groundwater condition was evaluated to increase groundwater elevation until the FS approached one.

Figure 4-6 shows the model evaluated with a residual friction angle of $28 \phi^{\prime} r$ and cohesion of $20 \mathrm{kPa}$, with the depth to groundwater recorded in hand augers HA-1 and HA-2 in March 2014 of $2.6 \mathrm{~m}$ and $3 \mathrm{~m}$, respectively. The model results indicate a $\mathrm{FS}=1.109$ under measured groundwater conditions. Figure 4-7 shows the model evaluated with a residual friction angle of $28 \phi^{\prime} \mathrm{r}$ and cohesion of $20 \mathrm{kPa}$, with a high groundwater table that was adjusted to approach about FS=1. Groundwater elevation was varied to determine potential future conditions needed to reactive the landslide. Groundwater was increased by approximately one meter and a FS of 1.009 was obtained. 


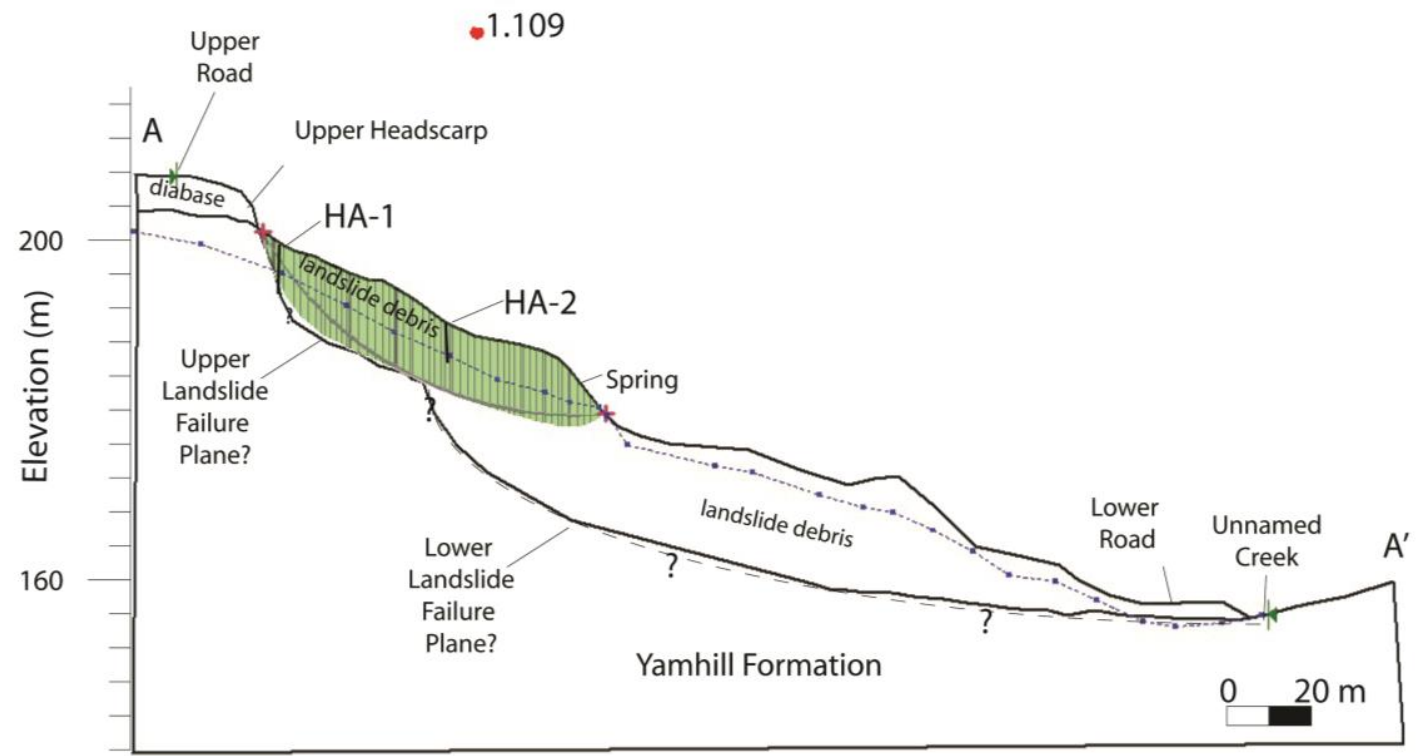

Figure 4-6. SLOPE/W slope stability model showing measured groundwater conditions, residual friction angle of $28 \phi^{\prime} r$ and cohesion of $20 \mathrm{kPa}$. Resulting FS=1.109.

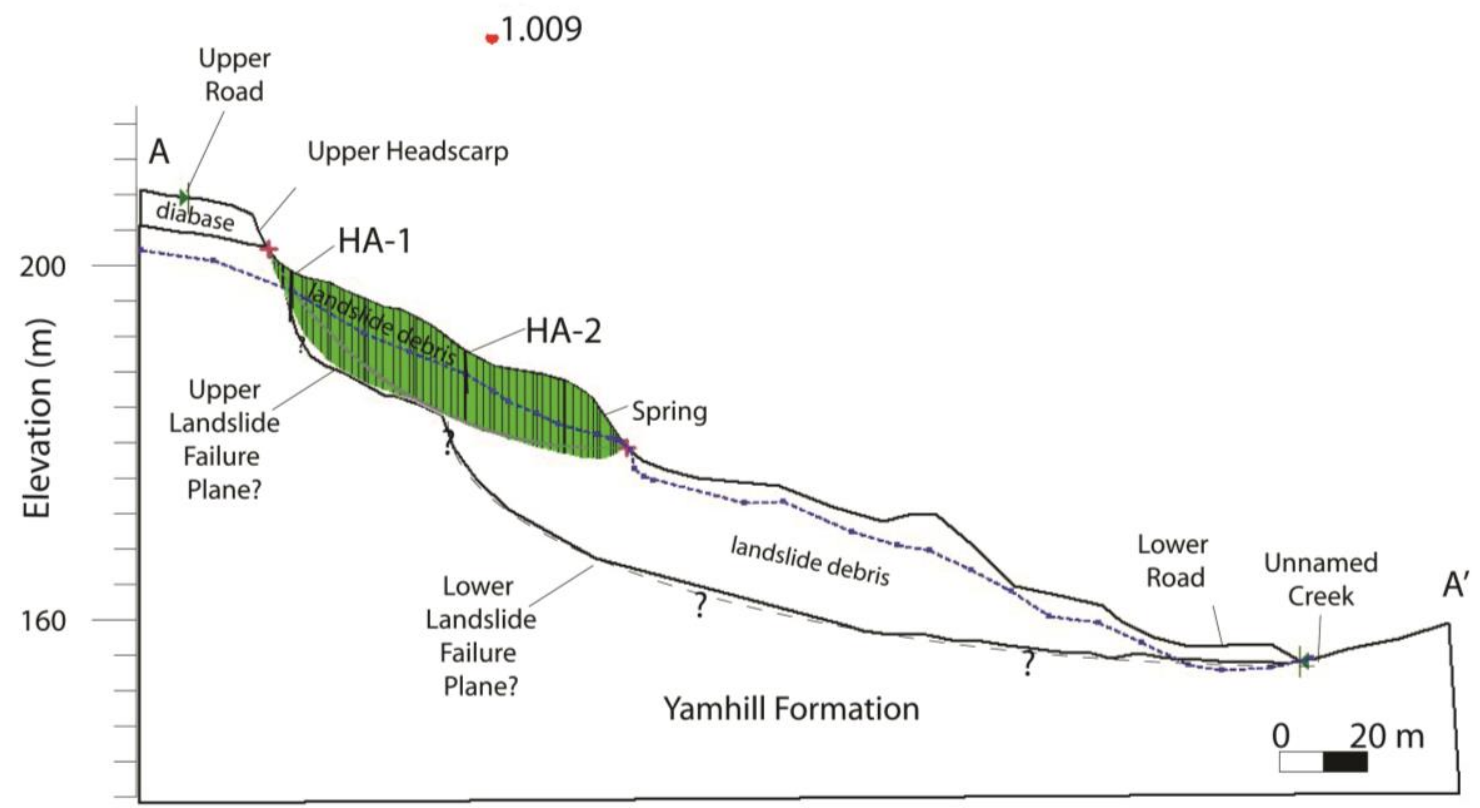

Figure 4-7. SLOPE/W slope stability model showing high groundwater conditions, residual friction angle of $28 \phi^{\prime} \mathrm{r}$ and cohesion of $20 \mathrm{kPa}$. Resulting FS=1.009. 


\subsection{Lidar Data Comparison}

DEMs generated from the lidar elevation data were used for a slope derivation of the lidar displaying surrounding topography and enhanced landslide terrain. Lidar elevation data from the April 2012 data collection event is used for a base map for DoD Figure 4-8 through Figure 4-11. The slope derivative map aided the visual interpretation of features characterizing the landslide in regards to depletion and accumulation zones.

Elevation data differencing to produce DoDs highlighted the elevation changes from the sequential lidar data collection events. Mickelson (2011) evaluated DoD for September and December 2007, December 2007 and March 2009, March 2009 and March 2010 and presented only positive and negative elevation changes for these data. This is expanded here to provide quantification of elevation changes. Burns et al. (2010) cautioned that great care was needed when interpreting volume changes due to the impact of leaf-on/leaf-off conditions in the differential lidar DEM and actual changes caused by removal of material by transport and erosion must be taken into account when interpreting lidar-derived volumetric data. What is more, lower point could densities anticipated in the dense conifer forest on the Madrone Landslide introduce additional error into the DEM surface elevations. While quantification of elevation differences is presented here, the values should be considered estimates due to the inherent compounding error in the data processing.

The first period of calculated DoD, September 2007 - December 2007, the elevation increased up to $3.5 \mathrm{~m}$ at the toe area of the upper landslide and decreased up to $4.2 \mathrm{~m}$ 
in the head area of the upper landslide. Figure 4-8 shows the location of elevation changes that occurred and are predominantly centered at the headscarp and toe of the upper landslide. Minor elevation changes can were calculated within the body of the lower landslide mass and outside of the landslide terrain.

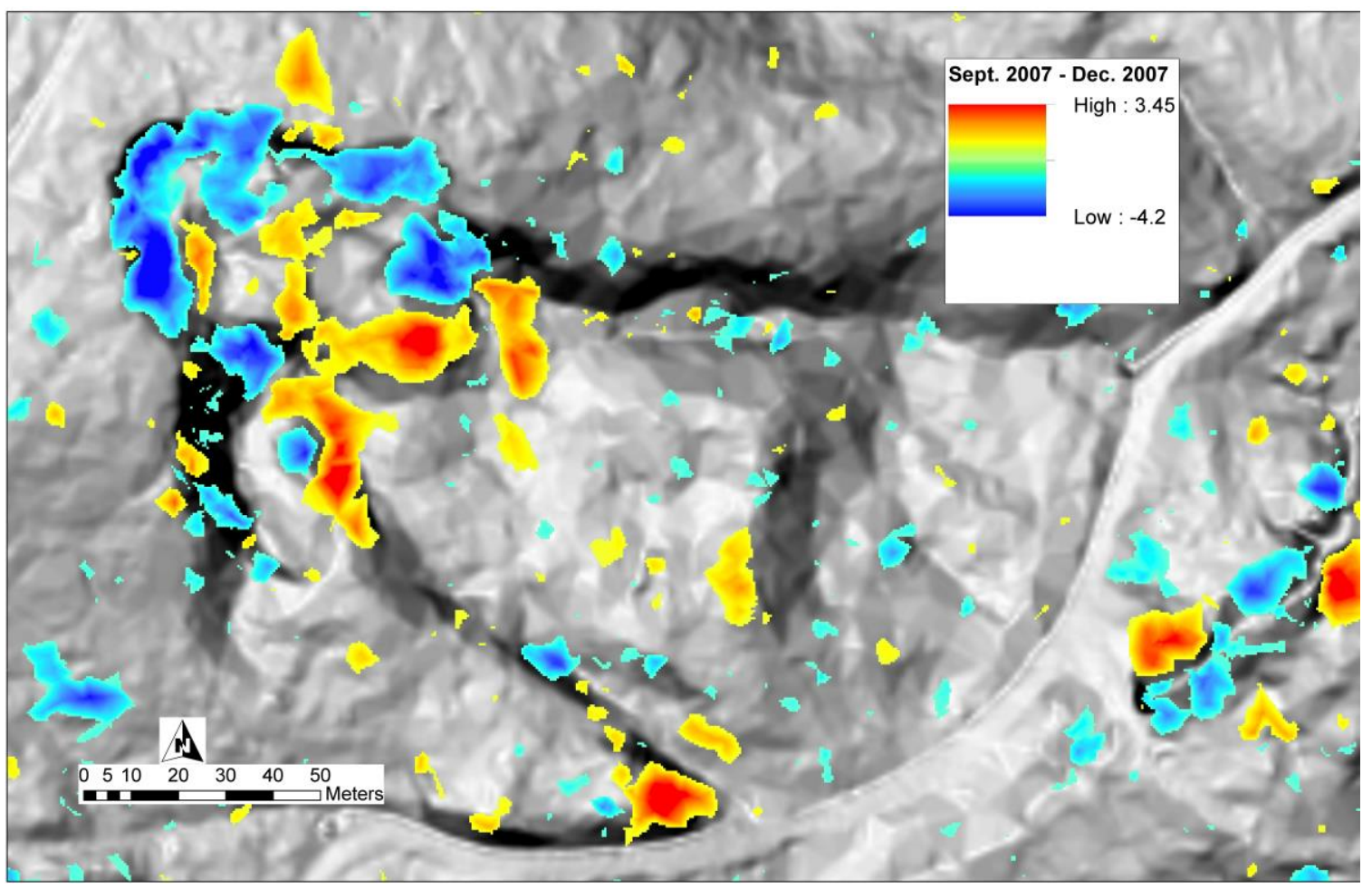

Figure 4-8. First period of differential lidar data September 2007 to December 2007. The data collected in December 2007 were subtracted from the data collected in September 2007 to produce the elevation changes presented in the figure. Warm colors represent an increase in elevation and cool colors represent a decrease in elevation. Over this time period, and bracketing a significant storm event, elevation increased up to $3.5 \mathrm{~m}$ at the toe area of the upper landslide and decreased up to $4.2 \mathrm{~m}$ in the head area of the upper landslide.

Elevation differences are shown at the downstream end of a culvert that is located near the toe of the lower landslide where substantial erosion was observed during fieldwork due to undercutting of the embankment fill of the culvert. In addition, areas 
associated with the lower landslide mass do not appear to have undergone significant changes in elevation anticipated for accumulation and depletion zones that should occur from landslide movement. Substantial elevation changes apparently not associated with landslide movement may be due to calculation errors from leaf-on verse leaf-off differencing. What is clear, that the DoD shows decrease in elevation at the head scarp and increase in elevation near the toe of the upper landslide in the down slope direction.

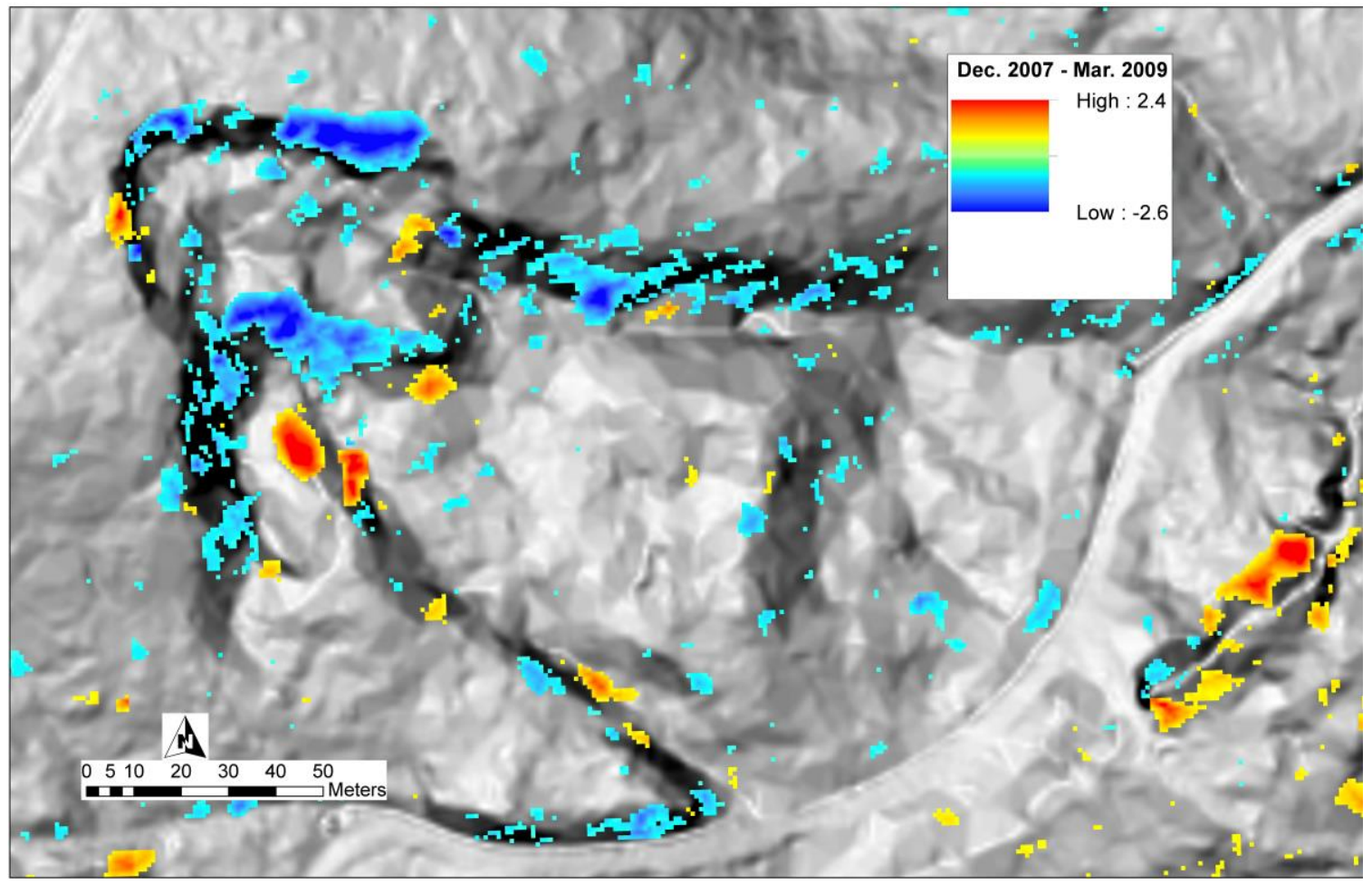

Figure 4-9. Second period of differential lidar data December 2007 to March 2009. Warm colors represent an increase in elevation and cool colors represent a decrease in elevation. Elevation increased up to $2.4 \mathrm{~m}$ at the ridge associated with the graben for the lower landslide and downstream side of the culvert. Elevation decreased up to $2.6 \mathrm{~m}$ in the head area of the upper landslide. 
The second period of sequential lidar DoD, December 2007 to March 2009 shows that changes in elevation in the lidar data occurred, however, the regions of the landslide terrain that indicates movement are not consistent with decrease in elevation in the depletion zone and increase in elevation in the accumulation zone. What is shown on Figure 4-9, is a decrease in elevation predominantly on the headscarp area of the upper landslide. In addition, a decrease in elevation is shown along the scarp where the upper landslide is overriding the lower landslide. Decrease in elevation is also shown at the headscarp for the lower landslide. Increases in elevation were calculated along the ridge associated with the graben for the lower landslide.

The third period of sequential lidar DoD, March 2009 to July 2010 DoD, elevation increased along the headscarp of the upper landslide and decreased at the ridge associated with the graben for the lower landslide in relatively the same areas shown for the second period DoD. 


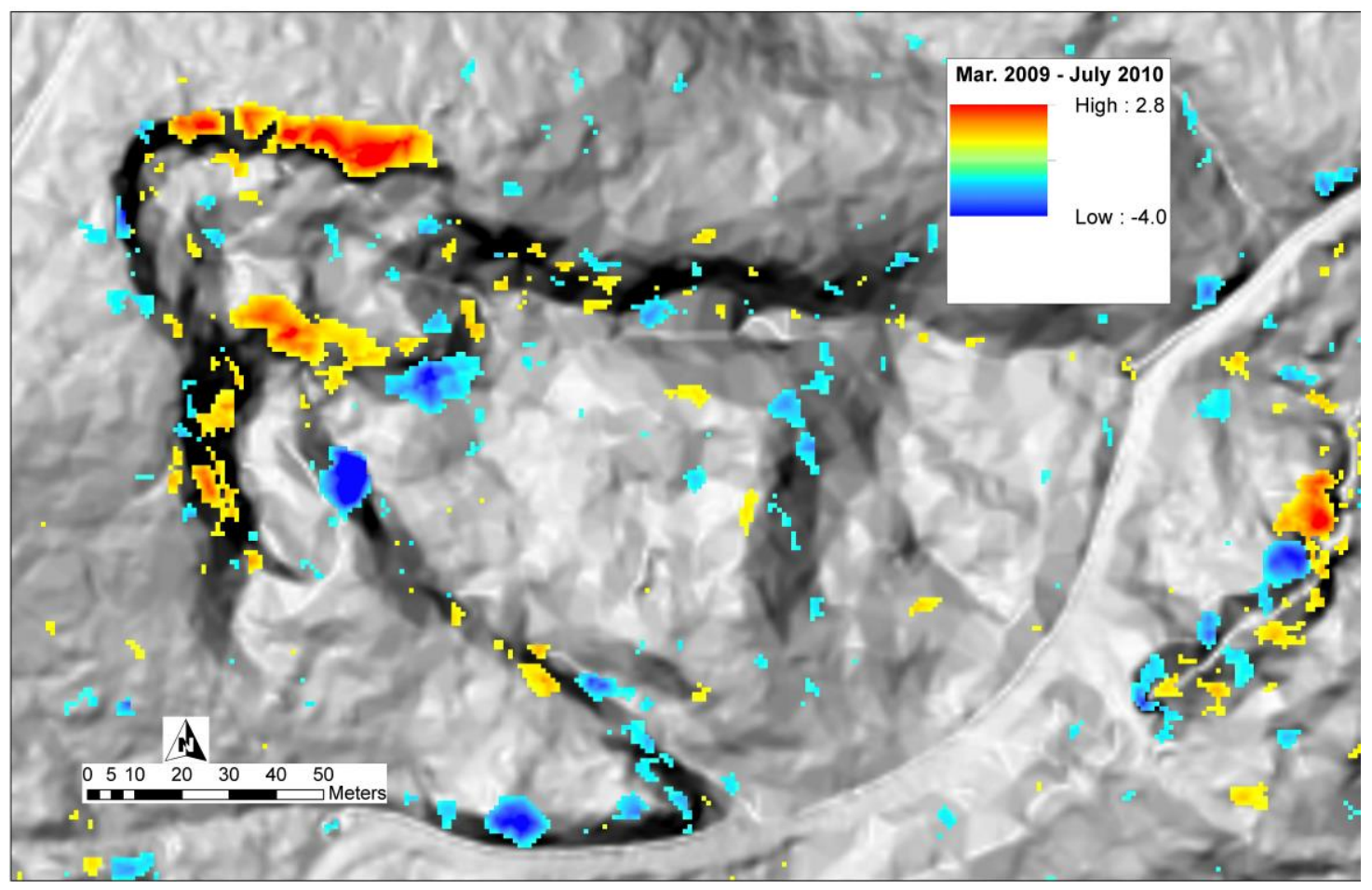

Figure 4-10. Changes in elevation calculated from March 2009 to July 2010, where elevation increased along the headscarp of the upper landslide and decreased at the ridge associated with the graben for the lower landslide.

The fourth period of sequential lidar DoD, April 2011 to April 2012 shows minor changes in elevation. Increase in elevation was calculated along the headscarp of the upper landslide, along the ridge associated with the graben for the lower landslide, and along the downstream portion of the culvert. Compared to previous periods of DoD, the fourth period shows the lowest overall changes in elevation and the smallest areas impacted by changes in elevation. These areas are also isolated to steep slopes where soil is exposed. As presented on Figure 4-11, changes in elevation up to $2 \mathrm{~m}$ were calculated along the headscarp of the upper landslide and decreases in elevation were observed up to $2.1 \mathrm{~m}$ below the downstream end of the culvert near the toe of the lower landslide. 


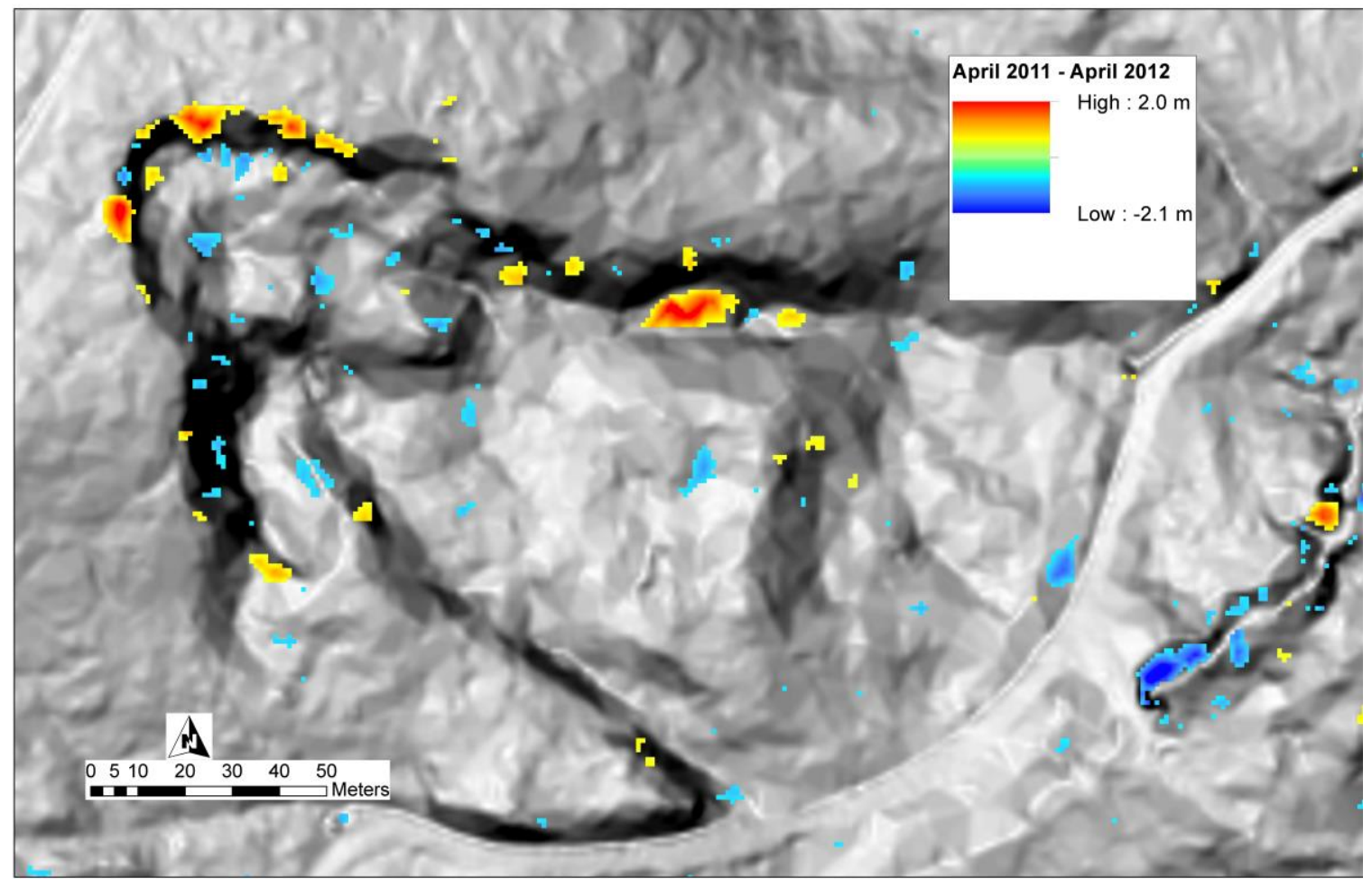

Figure 4-11. Changes in elevation up to $2 \mathrm{~m}$ were calculated along the headscarp of the upper landslide and decreases in elevation were observed up to $2.1 \mathrm{~m}$ below the downstream end of the culvert near the toe of the lower landslide. 


\section{CHAPTER 5 Discussion}

Burns et al. (2010) concluded that the volumetric calculations between two lidar datasets suggested the Madrone Landslide as a mass with high changes in volume. The differential lidar examined with the largest volume changes between the September 2007 and December 2007 data sets. This apparent movement resulted after a high precipitation event that occurred on December 3, 2007.

Historical aerial photograph evaluation suggests the upper landslide failed during the period between 2005 and 2009. This time frame coincides with the precipitation event that occurred on December 3, 2007 where a peak daily rainfall of $221 \mathrm{~mm}$ was recorded during one day.

The FS under static conditions with measured groundwater levels and residual strength parameters obtained in the laboratory was 1.109 . The results suggest that the upper Madrone Landslide is marginally stable under observed groundwater levels. For wet conditions with high water table, where groundwater elevation was only increased by approximately $1 \mathrm{~m}$, the FS was 1.009 . Based on the slope stability modeling results, a high groundwater surface approximately one to two meters below the ground surface appear to be necessary for landslide reactivation to occur.

Differential lidar data processed for this study indicates that between September 2007 and December 2007, elevation decreased significantly in the head area of the upper landslide and increased in the toe area of the upper landslide. These changes in elevation are consistent with decrease in elevation in the depletion zone and increase in 
elevation in the accumulation zone suggestive of landslide movement (Burns et al., 2010). Elevation changes calculated in the depletion and accumulation areas for the differential lidar pairs after 2007 do not show elevation changes consistent with landslide movement. The above average peak daily rainfall that occurred in January 2009 and November 2012, did not appear to have substantial enough rainfall to trigger landslide reactivation as also indicated in the differential lidar pairs between these events. The threshold for reactivation of the Madrone Landslide appears to be above $200 \mathrm{~mm} /$ day accompanied with a high groundwater surface for movement to occur in this large, deep-seated landslide.

It appears that heavy rainfall and likely high groundwater surface following the December 3, 2007 storm may have caused the upper landslide to fail thus overriding the lower landslide and retrogressing upslope. This failure event was captured by multitemporal aerial photographs and lidar data. The best estimate of the specific day of slope failure can be approximated by the evaluation of precipitation data which suggests the upper Madrone Landslide most likely failed on December 3, 2007.

These results demonstrate that the acquisition of relatively high accuracy elevation data from lidar can provide rapid landslide assessment following significant storm events. High landslide risk areas can be identified by baseline lidar landslide inventory assessments. These risk areas may be the focus of post storm assessments where future risk can be identified and appropriate mitigation approaches addressed prior to significant tragedy or loss of property. It is important to note that quantification of 
landslide volume changes by multi-temporal lidar differencing should be considered estimations and these data may be more useful as a qualitative screening tool for active landslide areas rather than as a measurement tool. 


\section{CHAPTER 6 Conclusions}

The Madrone Landslide (45.298383/-123.338796) is located in Yamhill County, about $12 \mathrm{~km}$ west of Carlton, Oregon. Site elevation ranges from $206 \mathrm{~m}$ national vertical geodetic datum (NVGD-88) near the head scarp to $152 \mathrm{~m}$ at the toe.

Mickelson (2011) identified the Madrone landslide as a potentially active mass during inventory mapping for the Panther Creek area. In addition, Burns et al, (2010) concluded that the volumetric calculations between two lidar datasets suggested the Madrone Landslide as a mass with high changes in volume. This landslide was therefore the prime candidate to study movements of a large, deep-seated landslide for this thesis.

The upper Madrone Landslide appears to be a classic deep-seated rotational slump landslide with indications of hyper concentrated flow at the toe. The lower landslide is much older than the upper landslide and is likely a dormant-mature landslide. The upper landslide has an area of $2,700 \mathrm{~m}^{2}$ and headscarp height that ranges from approximately $5 \mathrm{~m}$ to $7 \mathrm{~m}$. The depth to the failure plane in the upper landslide is estimated to be approximately $6 \mathrm{~m}$. A rough estimate of volume is approximately $15,700 \mathrm{~m}^{3}$. While much older than the upper landslide, the lower landslide appears to be an earthflow from evaluation of landslide morphology. The lower landslide is an area of approximately $23,000 \mathrm{~m}^{2}$ and an approximate scarp height of $15 \mathrm{~m}$. The depth to the 
failure plane is estimated to be approximately $12.5 \mathrm{~m}$. A rough estimate of volume is approximately $287,500 \mathrm{~m}^{3}$.

The landslide pair is located on a structural belt of uplifted Eocene to Miocene sedimentary and volcanic rocks (Wells et al., 1995). The Eocene deep marine sedimentary rocks of the Yamhill Formation consist of dark gray, massive to thinly bedded tuffaceous siltstone. The orientation of the bedding was measured with a Brunton compass at a strike of $280^{\circ}$ and a dip of $17^{\circ}$ to the southwest. The volcanic intrusions of the Diabase of Lee's Falls (Eocene to Miocene) are primarily diabase sills and dikes of aphyric to plagioclase-phyric diabase. Geologic mapping of the site indicates exposed diabase in the landslide headscarp, and scarp flank areas are predominantly decomposed and weather to a distinctive red soil observed at the ground surface over the majority of the landslide.

Annual cumulative precipitation data from the Haskins Dam MET station indicate an average annual cumulative precipitation of $1,976 \mathrm{~mm}$ near the site. The highest annual cumulative precipitation was in 1996 (2,932 mm) and the lowest was in 2013 (1,240 $\mathrm{mm}$ ). Precipitation data for 2013 indicates it was the driest year in the 18 years of recorded data. The average daily peak precipitation of $100 \mathrm{~mm}$ was exceeded three occasions over the course of lidar data collection: December 3, 2007 (221 mm), January 2, 2009 (103 mm), and November 19, 2012 (132 mm).

Historical aerial photograph evaluation was completed and suggests that failure of the lower landslide may have occurred between 1956 and 1963. Based on aerial 
photographs, the upper landslide appears to have failed during the period between 2005 and 2009. It should be noted that aerial photograph interpretation was difficult as a result of some poor quality photographs.

Ground crack monitoring stations were established at 20 locations to track potential ground movements. The statistical analysis of the crack monitoring measurements shows that crack measurements have small standard deviations. Standard deviations greater than 0.25 in. were recorded at monitoring stations $M 10, M 16, M 19$, and $M 20$. The small variations in measurements are likely the result of the difference in measurement tapes and measurement process. The lack of substantial measurement differences in ground crack monitoring suggests that the landslide essentially did not move between January 2013 and March 2014.

Subsurface materials and conditions were investigated with two hand-augered borings, designated HA-1 and HA-2, two hand dug soil pits designated SP-1 and SP-2, and four near surface undisturbed samples. In general, two material types were encountered and consisted of brown to reddish brown (2.5YR 4/6) silt and a light brown (10YR 7/4) silt. In March 2014, groundwater was encountered at a depth of $2.6 \mathrm{~m}$ in hand auger HA-1 and a depth of $3 \mathrm{~m}$ in hand auger HA-2. By May 2014, the groundwater depth increase to a depth of $3.8 \mathrm{~m}$ in hand auger HA-1 and was not encountered at the total depth of HA-2 at $4.5 \mathrm{~m}$.

Atterberg limit determinations were performed for six samples and plotting the PL against the $\mathrm{LL}$ indicates the soil can be classified as an $\mathrm{MH}$ soil. The unit weight for the 
soil is an average of $1.1 \mathrm{~g} / \mathrm{cm}^{3}$, and an undrained shear strength of $0.2 \mathrm{~kg} / \mathrm{cm}^{2}$ was determined for slope stability modeling input.

Direct shear testing was completed as a part of a nearby landslide investigation in the parent material mapped as the Nestucca Formation. The Yamhill Formation and the Nestucca Formation have very similar lithologies and depositional environments. The approximate residual shear strengths of two representative samples were determined to be $\phi^{\prime} r=28^{\circ}$ for landslide debris and $\phi^{\prime} r=39^{\circ}$ for of intact, relatively unweathered, siltstone. It is likely that the landslide mass has a lower overall angle of internal friction than the individual intact samples.

The development of the field-developed cross section was completed to show the main headscarp, estimated failure surface, hand auger locations, extent of landslide debris, and springs observed during field work. Cross section data were used in slope stability modeling (SlopeW with the Morgenstern Price model) to evaluate and determine the FS for static loading conditions for the upper landslide. A residual friction angle of $28 \phi^{\prime} \mathrm{r}$ and cohesion of $20 \mathrm{kPa}$ were used for a low groundwater condition model where depth to water of approximately $3 \mathrm{~m}$ below the ground surface produces a FS of 1.109. For high groundwater conditions, the groundwater table was elevated to approximately $2 \mathrm{~m}$ below the ground surface and resulted in a FS of 1.009. Additional increase in groundwater elevation from this point would reduce the FS to less than one and the landslide may reactivate. 
Lidar data in the Panther Creek Watershed were acquired on September 3, 2007, December 8, 2007, March 29, 2009, July 15, 2010, April 17, 2011, and April 27, 2012. Consecutive years were subtracted from previous years to generate a DoD (an output from the difference of elevation for each raster cell between years) and a threshold value of $0.5 \mathrm{~m}$ applied to reduce noise. DEMs generated from the lidar elevation data indicate the first period of calculated DoD, September 2007 - December 2007 had the most substantial elevation changes of increases up to $6.9 \mathrm{~m}$ at the toe area of the upper landslide and decreases up to $8.4 \mathrm{~m}$ in the head area of the upper landslide. Elevation changes primarily occurred at the headscarp and toe of the upper landslide. Weather data from a nearby station recorded a significant amount $(221 \mathrm{~mm})$ of rainfall on December 3, 2007. This storm event may have been the triggering event for the Madrone Landslide. The DoD for the second period (December 2007 to March 2009), the third period (March 2009 to July 2010), and fourth period (April 2011 to April 2012), show changes in elevation that are not consistent with decrease in elevation in the depletion zone and increase in elevation in the accumulation zone that would suggest slope movement. Elevation changes are predominantly observed in the headscarp area of the upper landslide, along the side scarp of the upper landslide, and along the ridge associated with the graben for the lower landslide. This suggests that slope failure did not occur during these periods and changes in calculated elevation differences are likely due to errors from leaf-on verses leaf-off data, soil erosion and transport, and lidar data processing errors. 
The largest change in landslide volume recorded from DoD analysis was between the September and December 2007 lidar flights. The highest peak daily rainfall was recorded on December 3, 2007, approximately five days prior to the lidar flight on December 8, 2007. The peak daily rainfall on December 3rd is nearly twice the amount as the next largest peak daily rainfall $(132 \mathrm{~mm})$ in 2012 and more than double the 18year average. The rainfall on December 3rd was $121 \mathrm{~mm}$ above the average daily peak rainfall for the 18 year period. No precipitation occurred two weeks prior to December 3rd and one week prior, precipitation was low until the day before the storm. Aerial photograph interpretation, precipitation data, and DoD analysis suggest that the storm event that occurred December 3, 2007 may have been a triggering event for the Madrone Landslide and that greater than about $200 \mathrm{~mm}$ of peak daily rainfall and high groundwater surface may be necessary to see reactivation of the Madrone Landslide.

The preceding work was conducted to define the characteristics of the Madrone Landslide through a field developed cross section, soils testing (Atterberg limits, soil density, and direct shear), depth to groundwater, and ground crack measurements in order to develop methods that can be used to study large, deep-seated landslides. The use of the lidar derived DoD and comparison to historical aerial photography and weather station data allowed for the estimated date of failure for the upper landslide. The process and methods discussed in this report can be transferred to other deep seated landslide investigations. 


\section{CHAPTER 7 Future work}

The investigation into the movement of the Madrone Landslide identified several key points of information that may have triggered slope failure. In the future, this work could be extended to a fully instrumented site by using the lessons learned from the work presented here. An electronic monitoring network could be established to continually monitor the behavior of the Madrone Landslide. The distance between rebar rods used for ground crack measurements should be measured with the same tape and in the same end of rod to reduce measurement errors. Ground crack monitors should also be placed in stable ground off the landslide mass to evaluate single movement of the entire landslide body. In addition, future work would benefit from the deployment of several piezometers that continually monitored groundwater levels in the landslide mass. What is more, a stream gauge and weather data collection station would have assisted in the interpretation of the behavior of the Madrone Landslide. Working in concert with water budget information for the landslide, in-place inclinometer could be installed to obtain a better more comprehensive understanding of the properties of the failure plane. A more extensive data set to evaluate may bring new understanding to the failure mechanisms of deep-seated landslides in marine sedimentary rock in the Oregon Coast Range. Understanding of the Madrone Landslide would also benefit from annual precipitation that approaches the threshold for slope movement. Landslide investigations conducted during an 18-year precipitation low period are bound to struggle for viable measurements of mass movement. 


\section{References}

Brownfield, M.E., 1982, Geologic Map of the Sheridan Quadrangle, Polk and Yamhill Counties, Oregon. Oregon Department of Geology and Mineral Industries. Geologic Map Series 23.

Burns, W.L., and Madin, I.P., 2009, Protocol for Inventory Mapping of Landslide Deposits from Light Detection and Ranging (LiDAR) Imagery. Special Paper 42. Department of Geology and Mineral Industries.

Burns, W., Coe, J.A., Kaya, B.S., 2010, Analysis of Elevation Change Detected from Multi-Temporal LiDAR Surveys in Forested Landslide Terrain in Western Oregon, Environmental \& Engineering Geoscience, Vol. XVI, No. 4, November 2010, pp. 315-341.

Burns, S.F., (1998) Landslides in the Portland area resulting from the winter storm of 1996 in: Burns, S.F., Editor, (1998) Environmental, Groundwater and Engineering Geology: Applications from Oregon, Star Publishing Co., Belmont, California, p. 367-372

Cornforth, D.H., 2005, Landslides in Practice: Investigation, Analysis, and Remedial Options in soil, John Wiley and Sons, Hoboken, New Jersey.

Cruden D.M., Varnes D. J., 1996, Landslide types and processes. In: Turner A.K.; Shuster R.L. (eds) Landslides: Investigation and Mitigation. Transp Res Board, Spec Rep 247, pp 36-75.

Davis, J.C., 2002, Statistics and Data Analysis in Geology. John Wiley and Sons, New York.

Dragert, H., Hyndman, R.D., Rogers, G.C., and Wang, K., 1994, Current deformation and the width of the seismogenic zone of the northern Cascadia subduction thrust: Journal of Geophysical Research, v. 99, no. B1, p. 653-668.

Geo-Slope. 2014. SLOPE/W ${ }^{\circledR}$, edition 8.13.1.9253, dated 2014, developed by GEO-SLOPE International Ltd. of Calgary, Alberta, Canada

Iverson, R.M., George, D.L., Allstadt, K., Reid, M.E., Collins, B.D., Vallance, J.W., Schilling, S.P., Godt, J.W., Cannon, C.M., Magirl, C.S., Baum, R.L., Coe, J.A., Schulz, W.H., and Bower, J.B., 2015, Landslide mobility and hazards: implications of the 2014 Oso disaster, Earth and Planetary Science Letters, 412, 197-208

Johnson, R.B., DeGraff, J.V., 1988, Principles of Engineering Geology. John Wiley and Sons, New York.

Keaton, J.R., and DeGraff, J.V., 1996, Surface observations and geologic mapping, In Turner, A.K., and Schuster, R.L., (eds) Landslides: Investigation and Mitigation, Transportation Research Board Special Report 247. National Research Council. National Academy Press. Washington, DC.

McCalpin, J., 1984, Preliminary Age Classification of Landslides for Inventory Mapping, in Proceedings 21st Engineering Geology and Soil Engineering Symposium: University of Idaho, Moscow.

Mickelson, K.A., 2011, LiDAR-Based Landslide Inventory and Susceptibility Mapping, and Differential LiDAR Analysis for the Panther Creek Watershed, Coast Range, Oregon. Master of Science. Portland State Geology Department.

Morgenstern, N.R. and Price, V.E., 1965, "The Analysis of the Stability of General Slip Surfaces." Geotechnique, Vol. 15, No. 1, pp. 79-93.

Niemiec, S.S., Ahrens, G.R., Willits, S. and Hibbs, D.E., 1995, Hardwoods of the Pacific Northwest, Research Contribution 8. Oregon State University, Forest Research Laboratory

Oregonian, 2007, "Death toll from storm in Oregon and Washington rises to 13". The Oregonian. December 6, 2007.

Snavely, P. D. Jr., Bukry, David, and Wells, R. E., 1993, Coccolith-bearing late middle Eocene kerogen shale, Tillamook Highlands, northwest Oregon Coast Range: U. S. Geological Survey Open-File Report 93-623, 13p.

Taylor G. 2014. Climate of Yamhill County Oregon, Prepared by George Taylor, State Climatologist. http://www.ocs.orst.edu/county_climate/Yamhill_files/Yamhill.html

Turner, A. K., and Schuster, R. L., editors, 1996, Landslides Investigation and Mitigation, Transportation Research Board, TRB Special Report 247, National Academy Press, Washington, DC, 673 pp.

USGS, 2006. U.S. Geological Survey, Quaternary fault and fold database for the United States, accessed 8/26/2014, from USGS web site: http//earthquakes.usgs.gov/regional/qfaults/.

Wieczorek, G.F., and Snyder, J.B., 2009, Monitoring slope movements, in Young, R., and Norby, L., Geological Monitoring: Boulder, Colorado, Geological Society of America, p. 245-271.

Wells, R.E., Snavely, P.D., MacLeod, N. S., Kelly, M.M., Parker, M.J., 1994, Geologic Map of the Tillamook Highlands, Northwest Coast Range (Tillamook, Nehalem, Enright, Timber, Fairdale, and Blane 15 minute Quadrangles) U.S. Geological Survey. Open File Report 94-21. 
Wells, R.E., Niem, A.R., Macleod, N.S., Snavely, P.D., and Niem, W.A., 1983, Preliminary Geologic Map of the West Half of the Vancouver (WA.-OR.) 1 X 2 Quadrangle, Oregon. Oregon Department of Geology and Mineral Industries Open File Report 0-83-6. U.S. Geological Survey Open File Report 83-591.

Williamson, D.A., Neal, K.G., Larson, D.A., 1991, The field developed cross-section: a systematic method of portraying dimensional subsurface information and modeling for geotechnical interpretation and analysis: Proceedings $34^{\text {th }}$ Annual Meeting Association of Engineering Geologists.

Wolf Read. "Great Coastal Gale of Dec. 1-3, 2007". Office of the Washington State Climatologist. Retrieved 2014-1227.

Yeats, R.S., Werner, KS; Popowski, TA, 1996, Geologic map of the Northern Willamette Valley, Clackamas, Marion, Multnomah, Polk, Tillamook, Washington, and Yamhill Counties, Oregon. in Rodgers, A.M., Assessing Earthquake Hazards and Reducing Risk in the Pacific Northwest. U.S. Geological Survey. Professional Paper 1560. Plate $2 a$. 
Appendix: Historical Aerial Photographs 


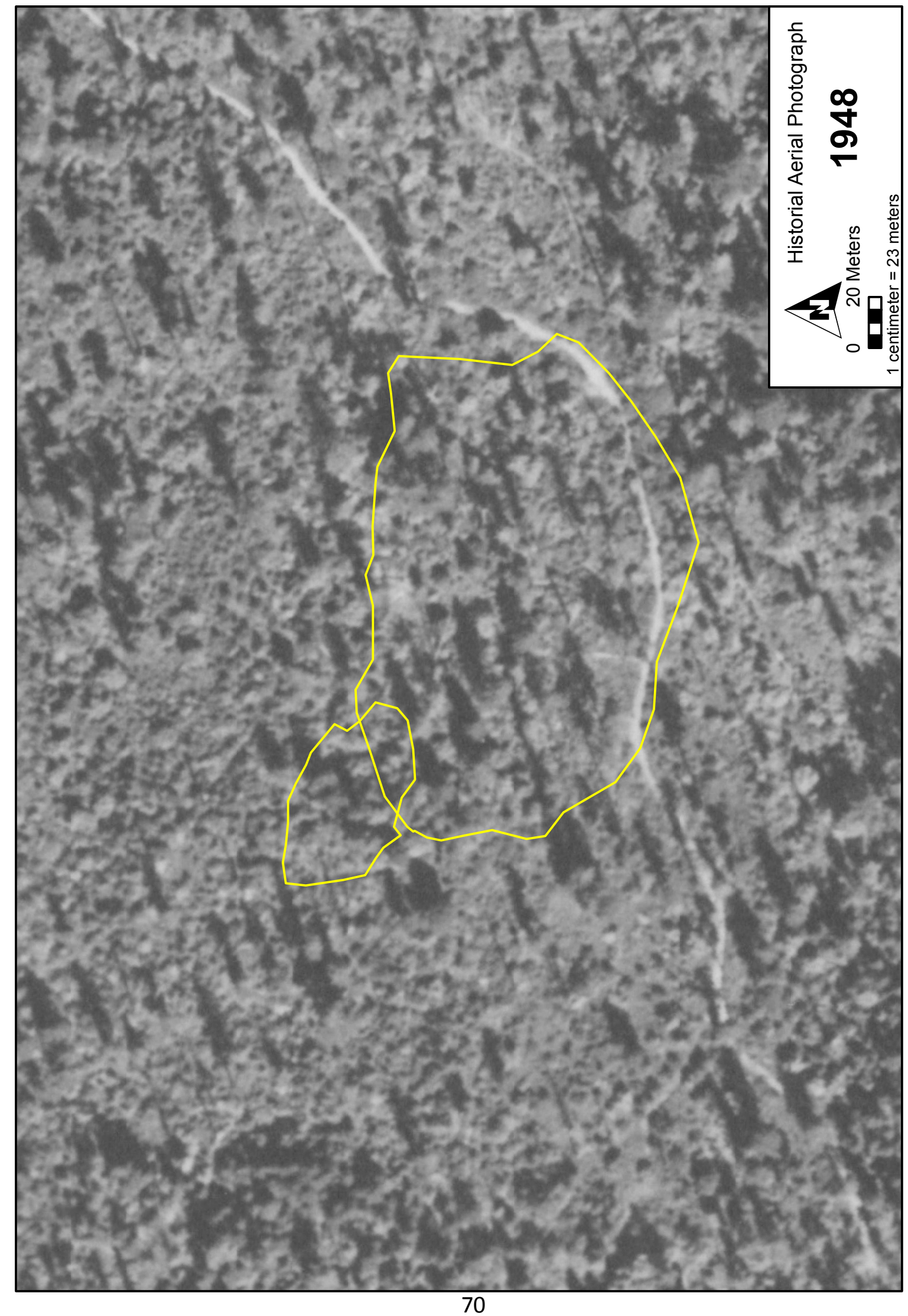




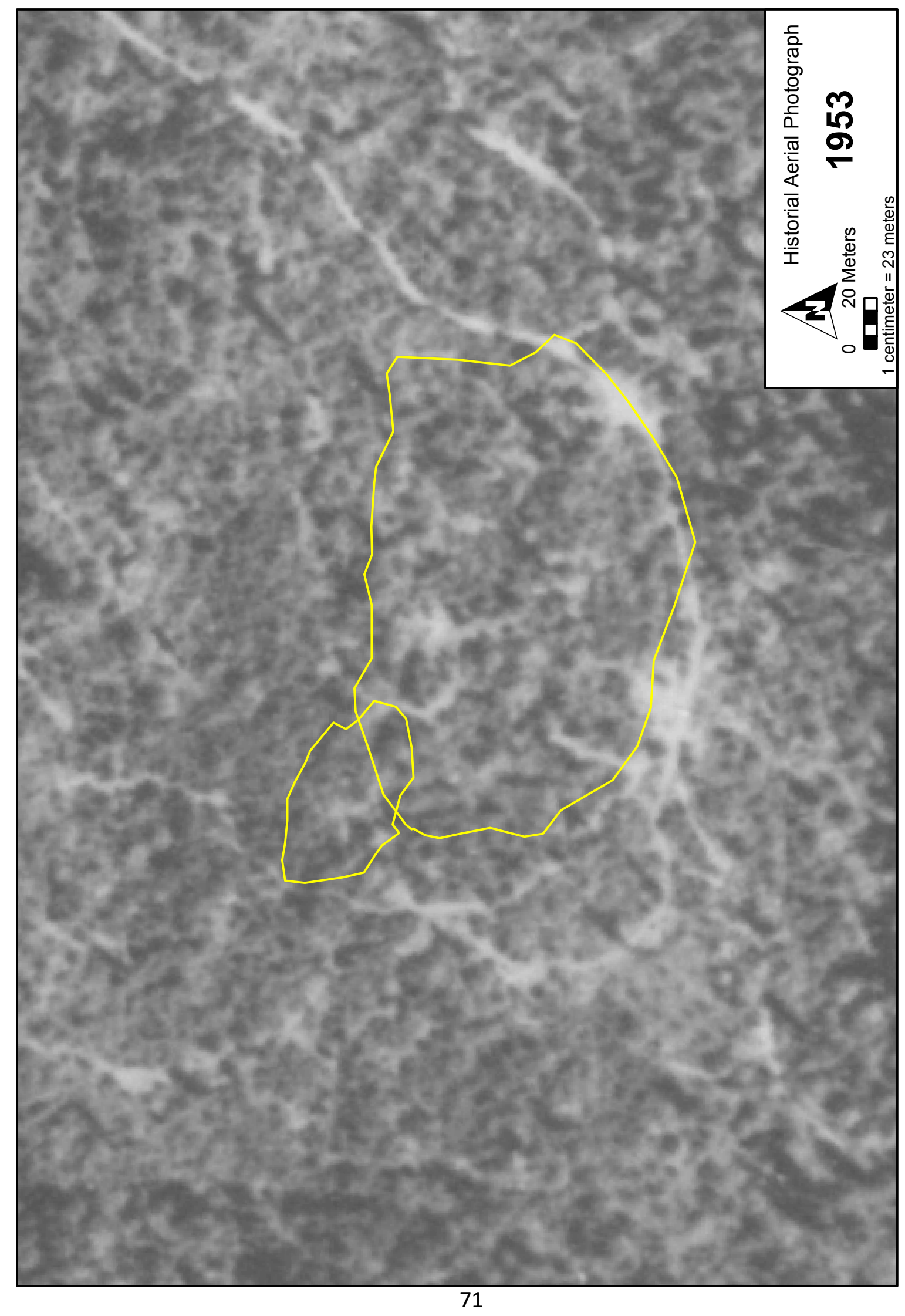




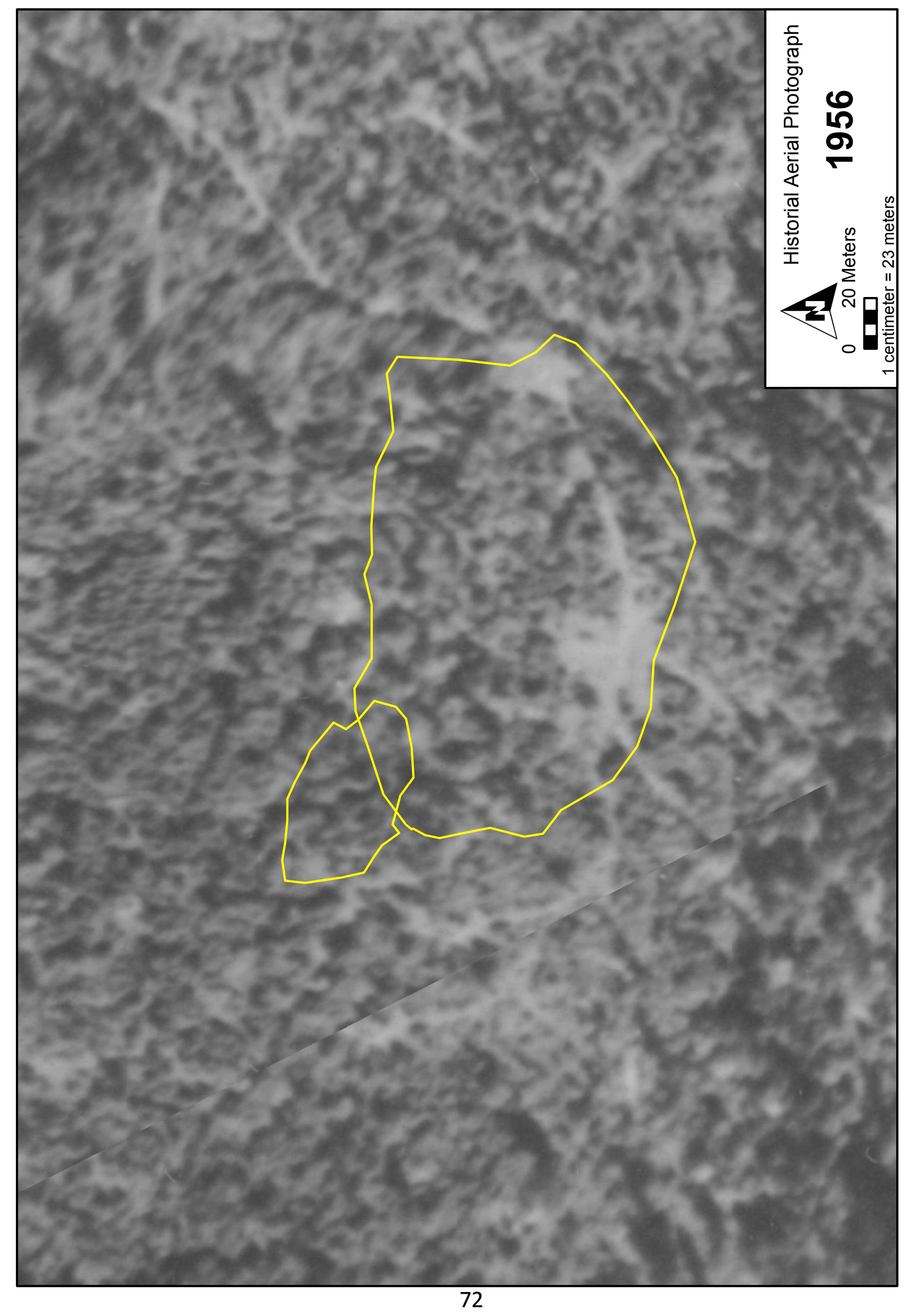




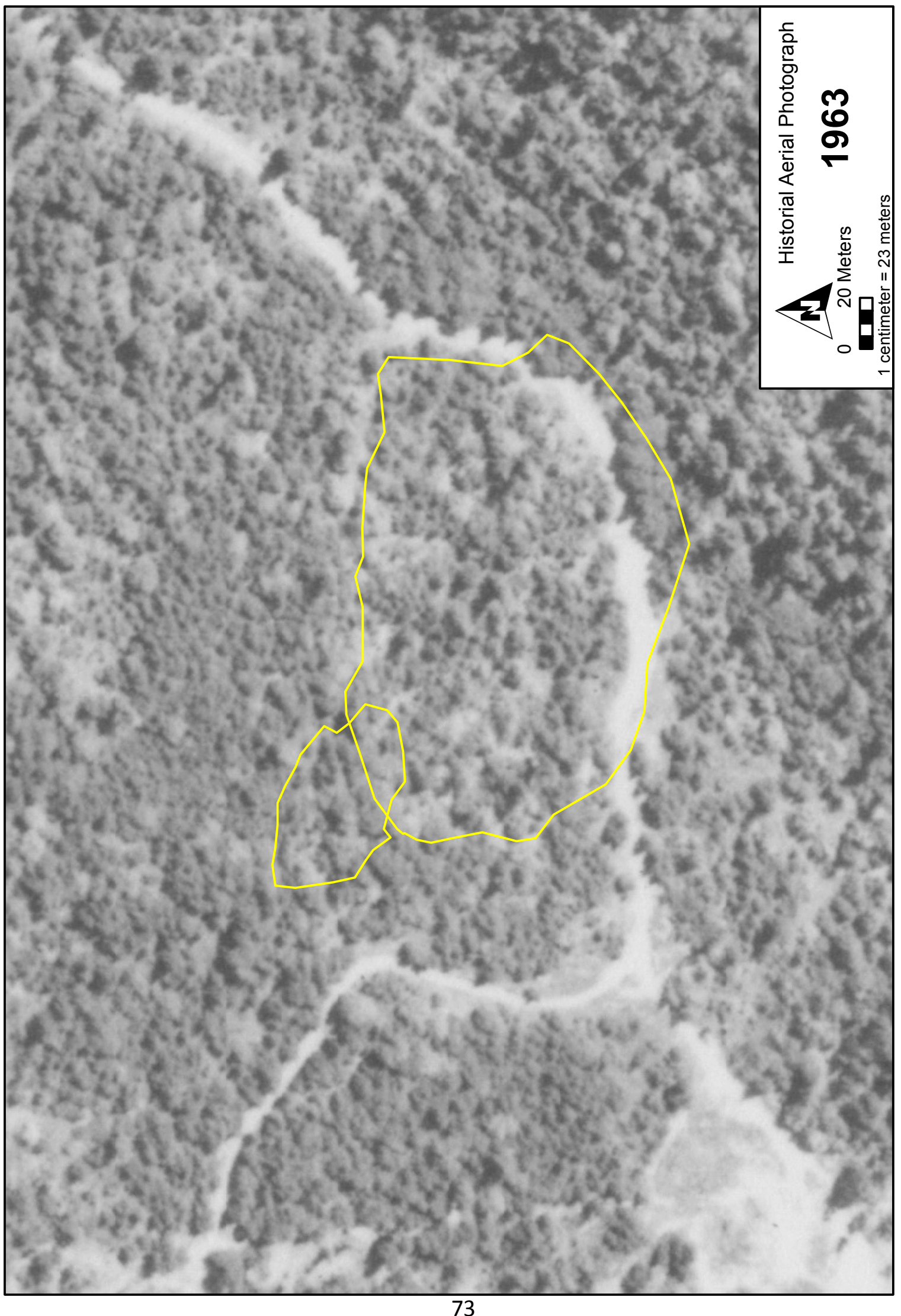




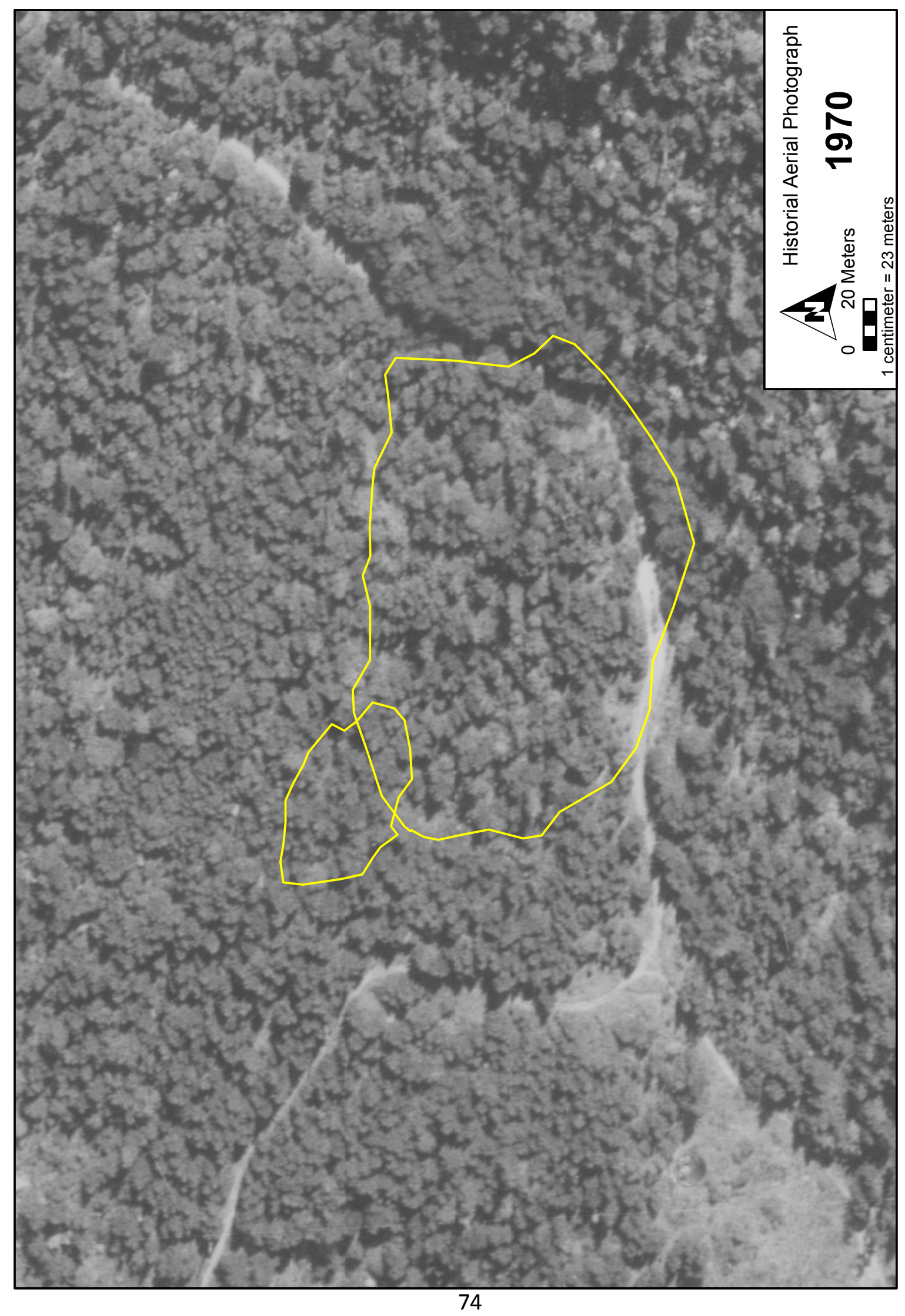




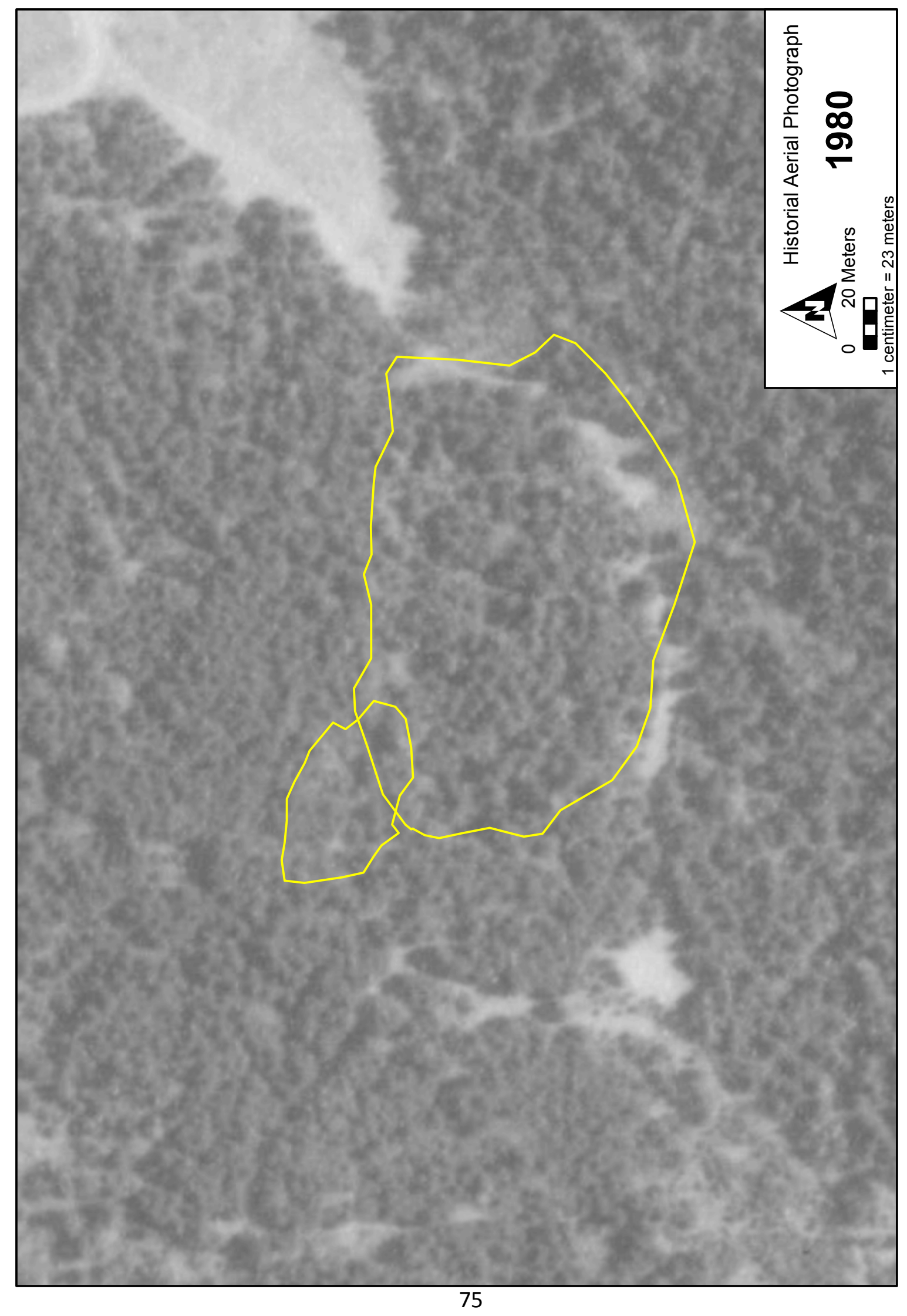




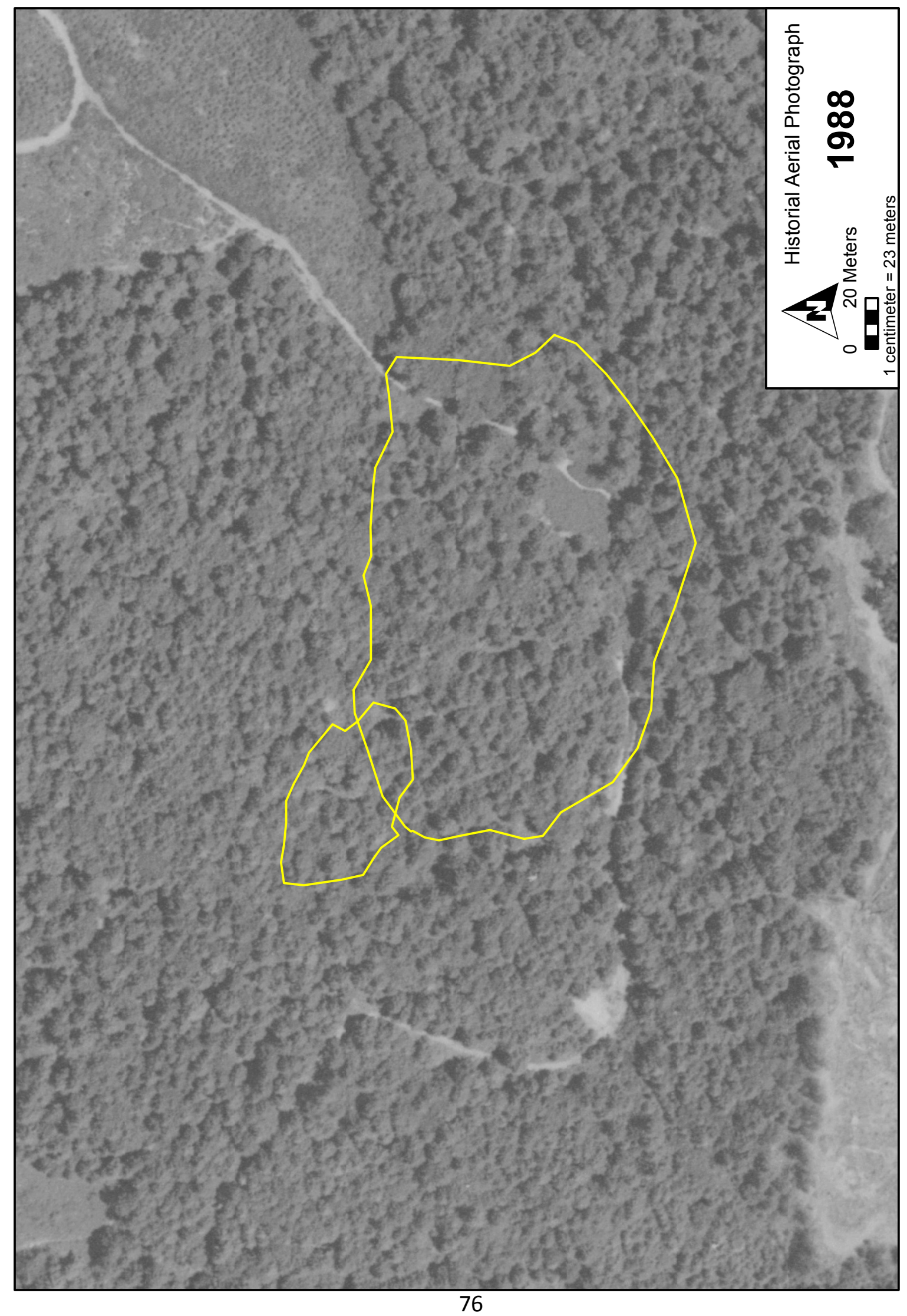




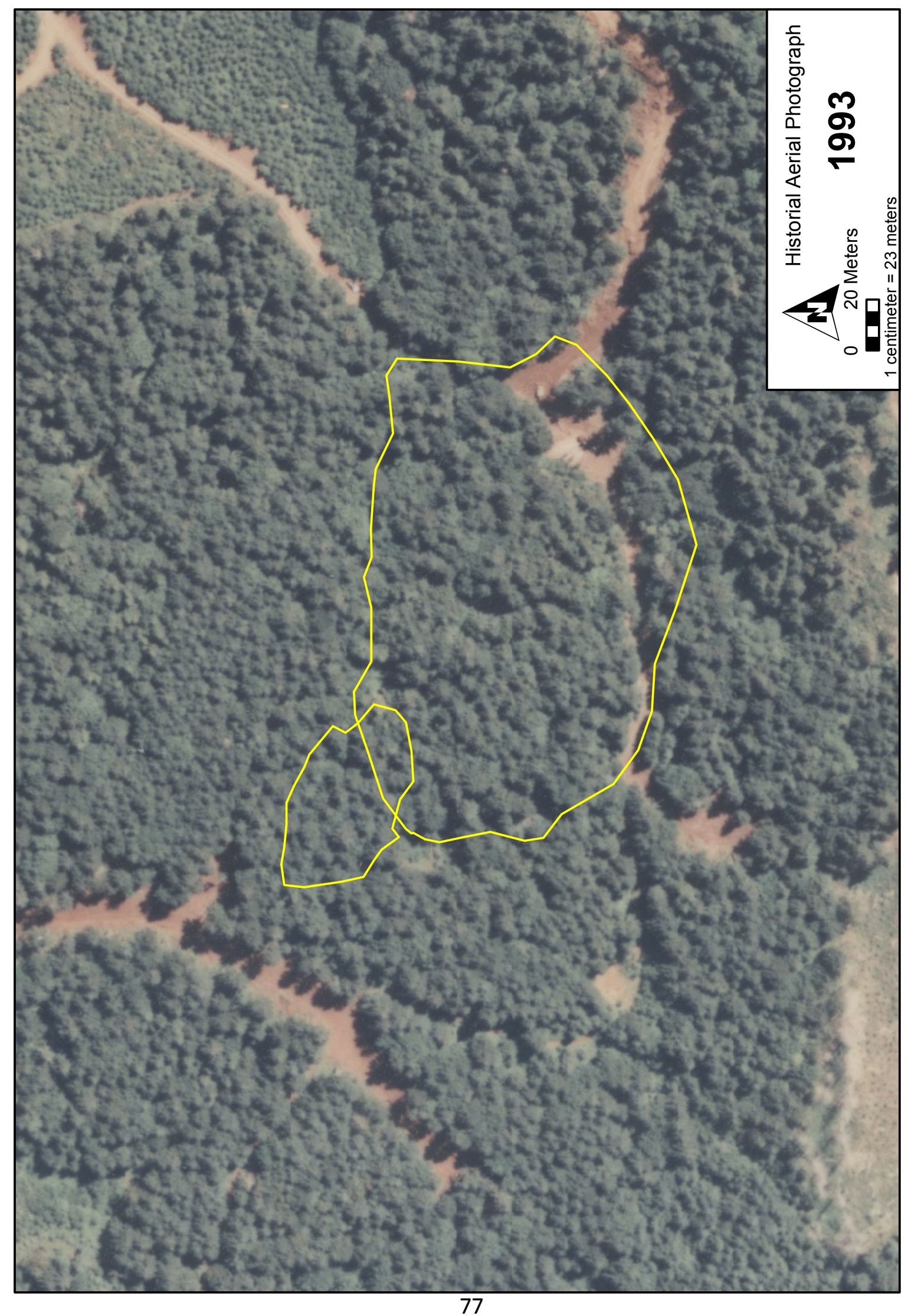




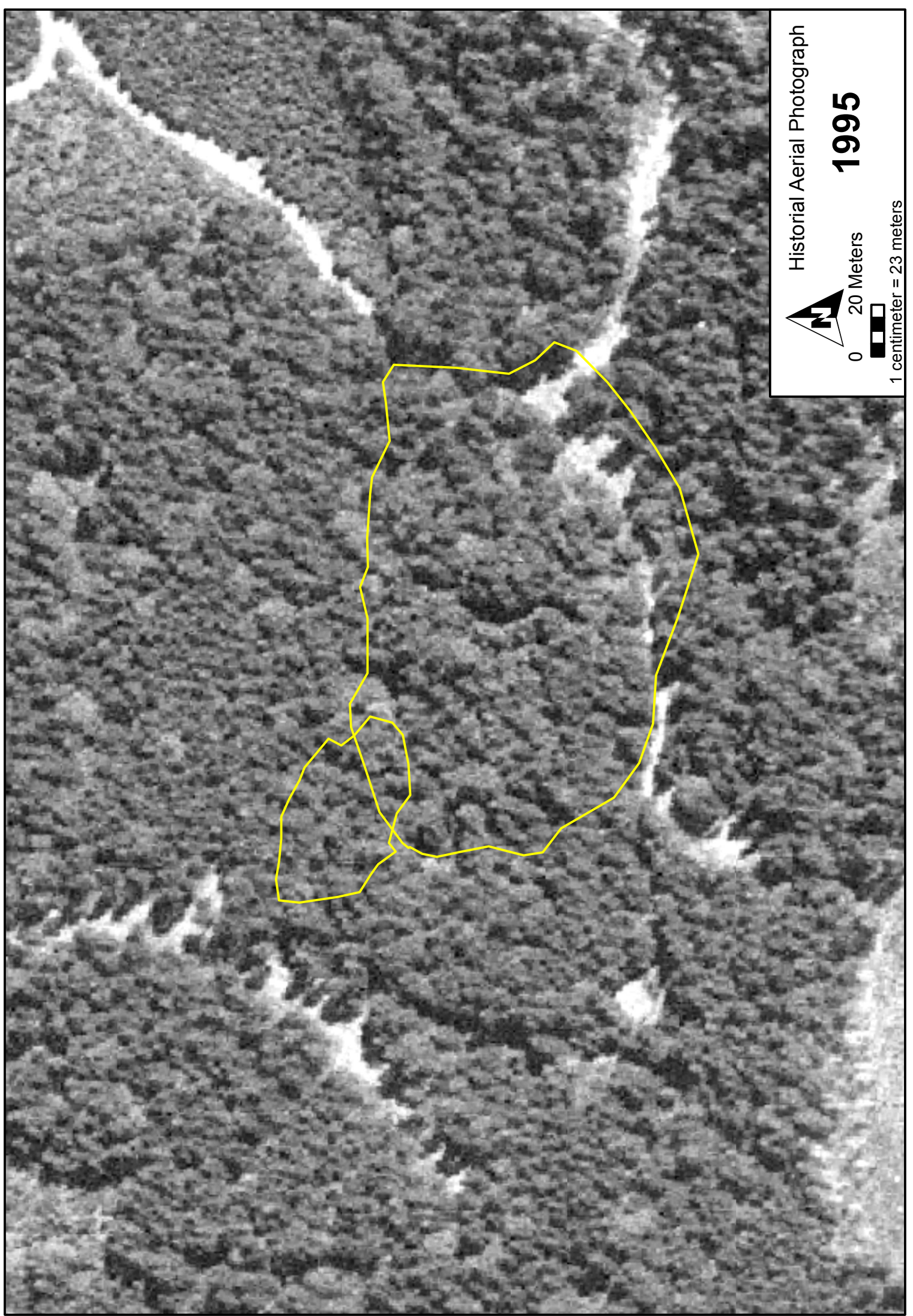




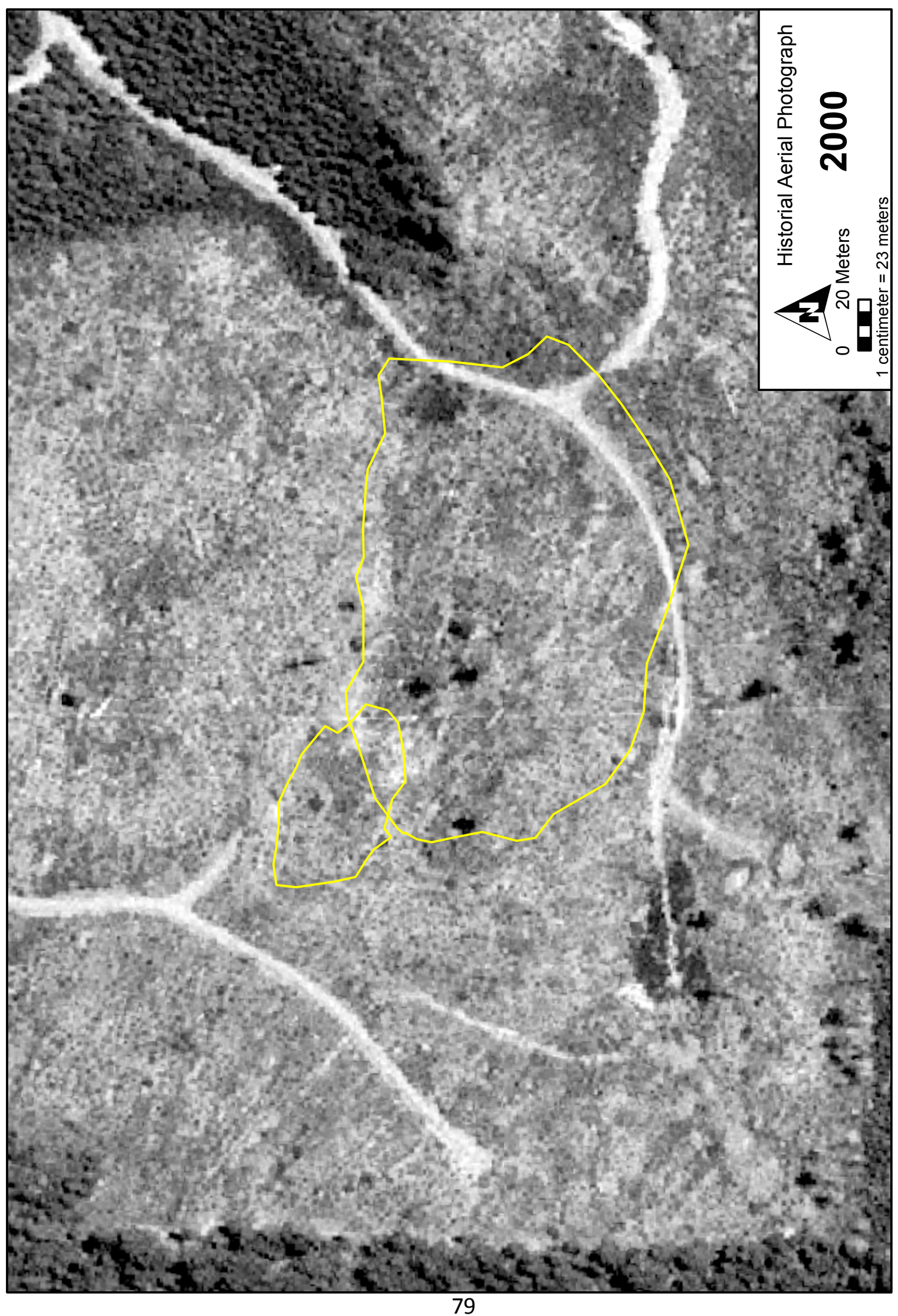




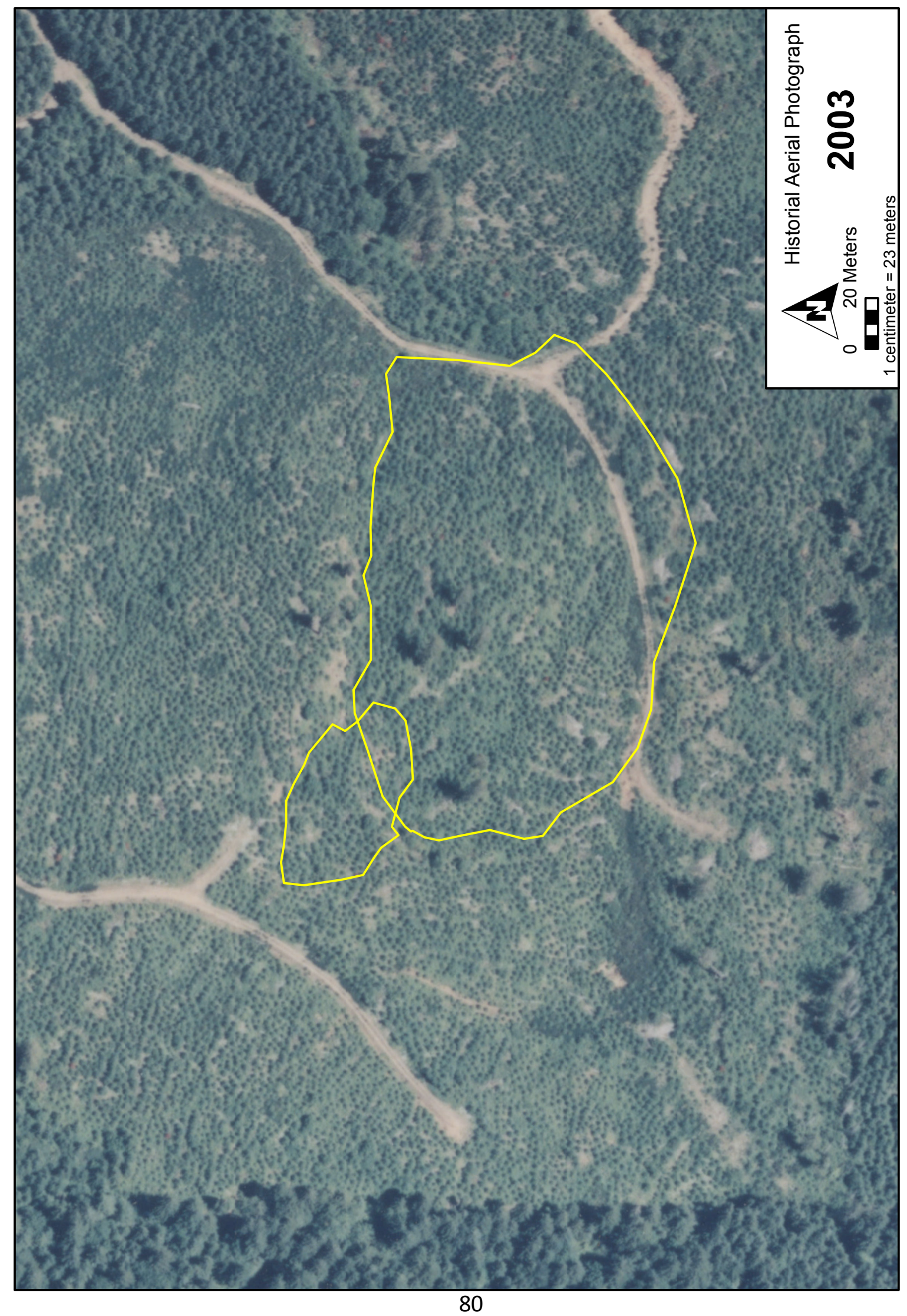




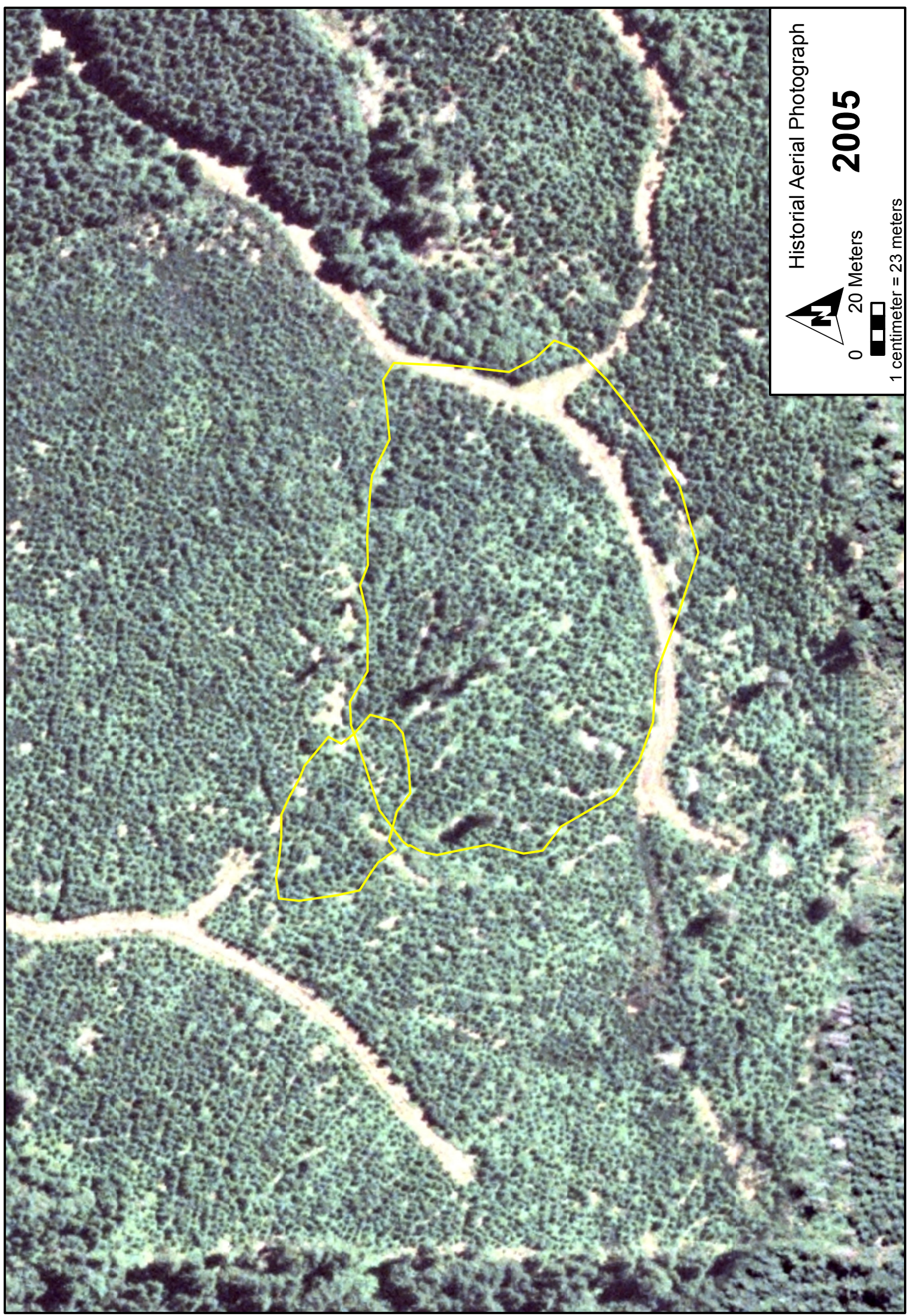




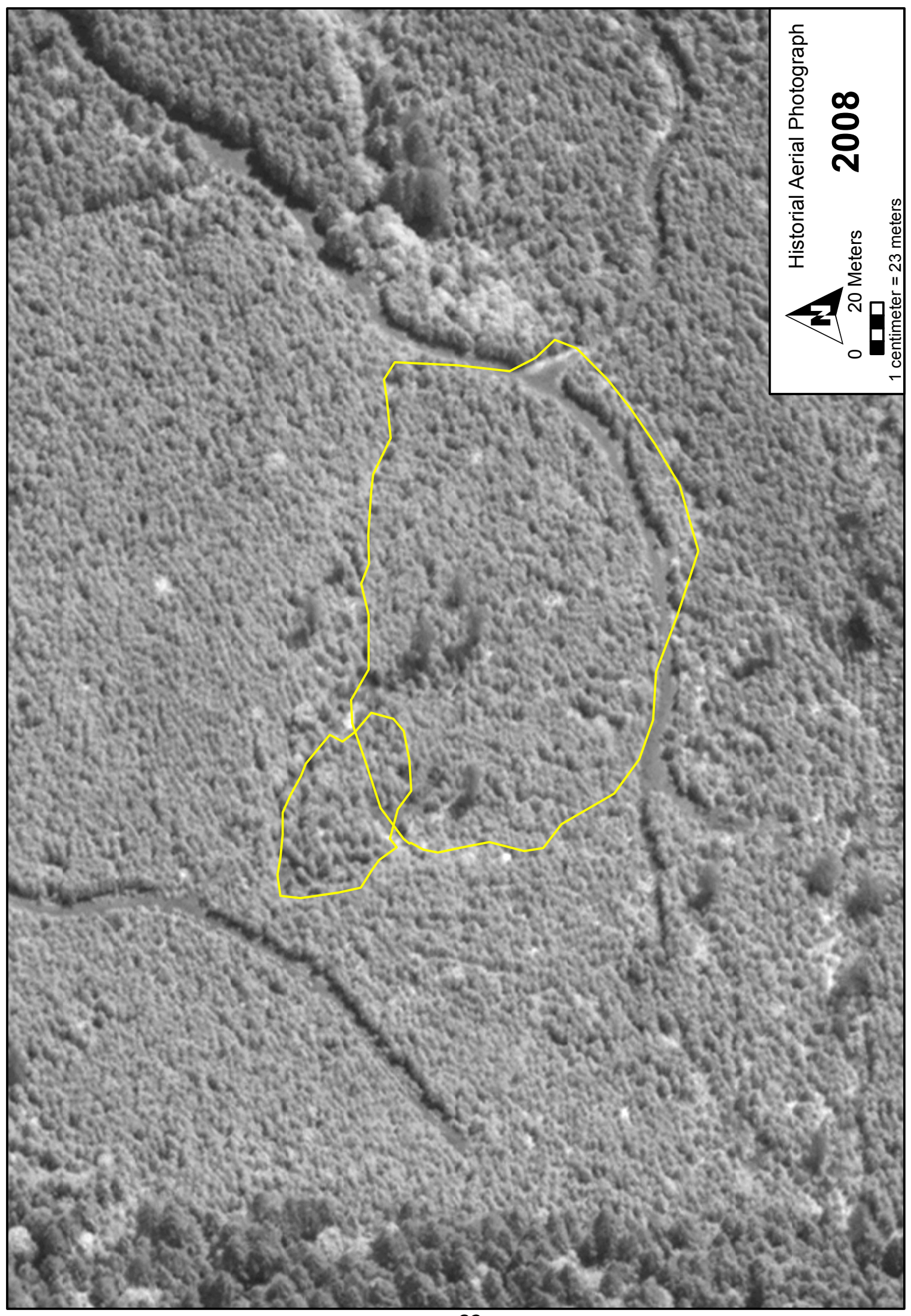




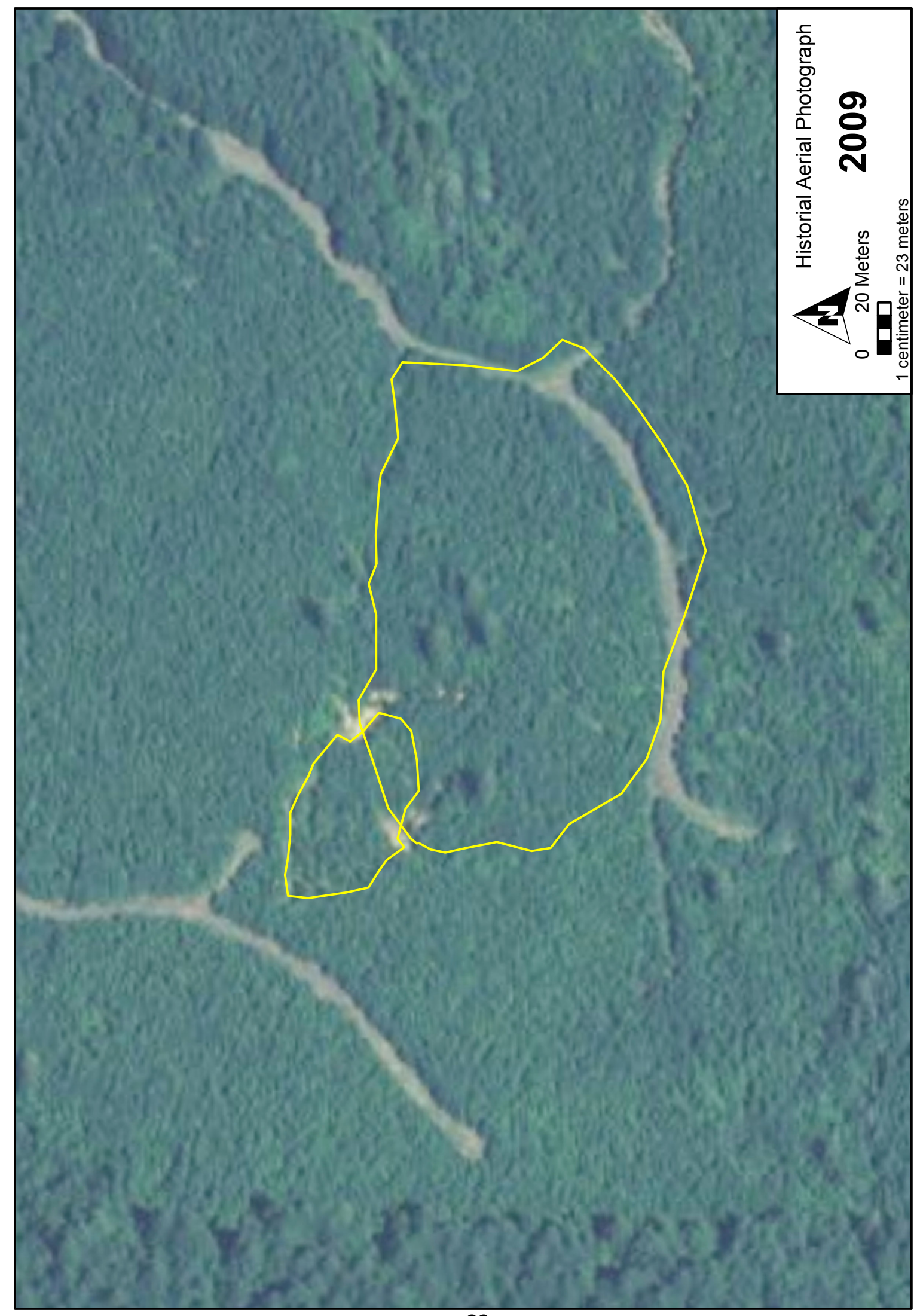




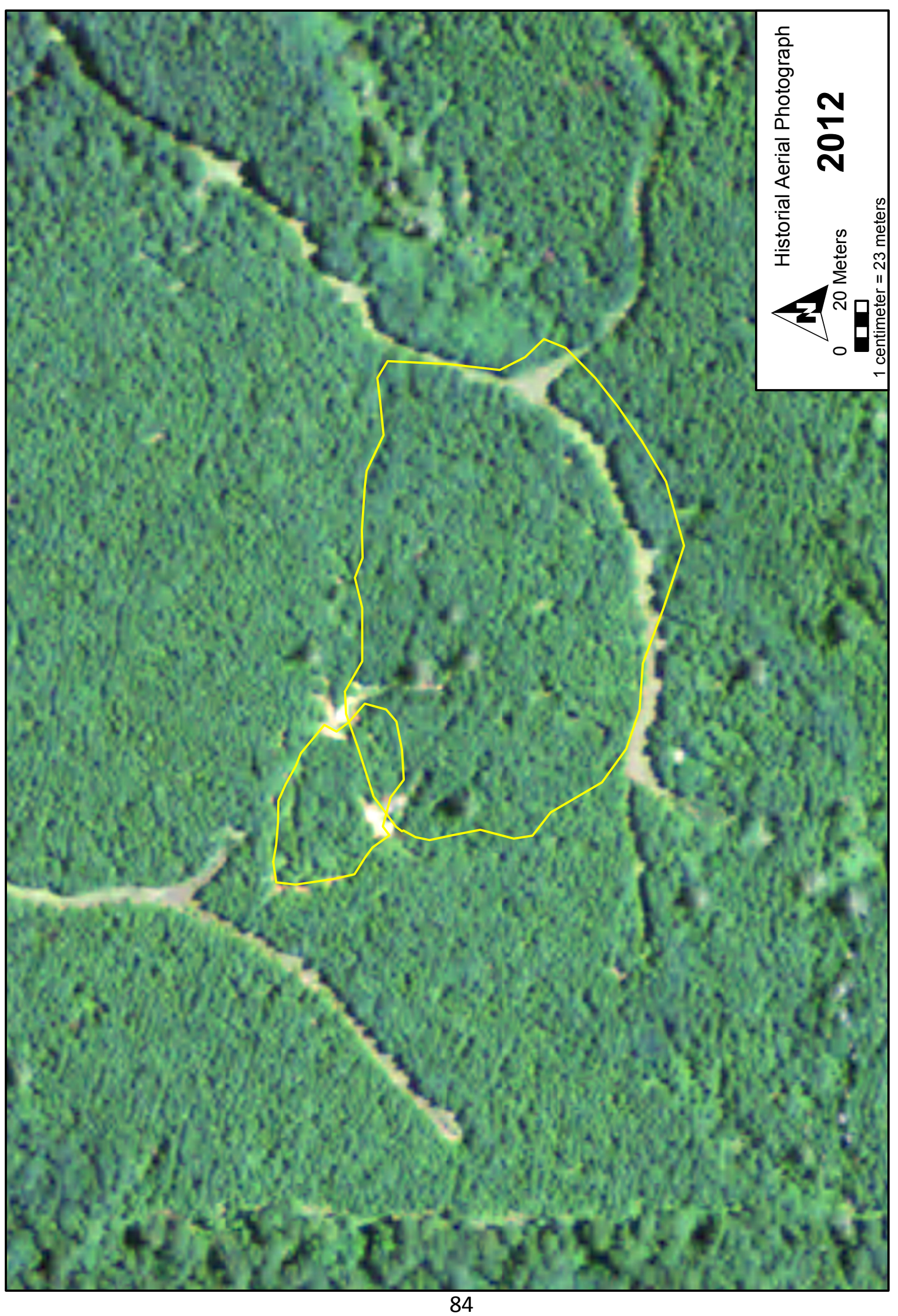

